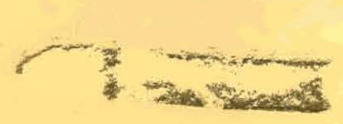

\title{
METHANOL PRODUCTION FROM EUCALYPTUS WOOD CHIPS
}

\author{
Attachment I \\ The Florida Eucalyptus Energy Farm \\ Silvicultural Methods and Considerations
}

April 1982

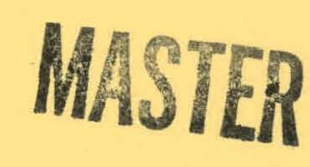

\author{
Prepared by \\ Biomass Energy Systems, Inc. \\ Lakeland, Florida \\ For the \\ U.S. Department of Energy \\ Office of Alcohol Fuels \\ Under Grant No. DE-FG07-80RA50316
}




\section{DISCLAIMER}

This report was prepared as an account of work sponsored by an agency of the United States Government. Neither the United States Government nor any agency Thereof, nor any of their employees, makes any warranty, express or implied, or assumes any legal liability or responsibility for the accuracy, completeness, or usefulness of any information, apparatus, product, or process disclosed, or represents that its use would not infringe privately owned rights. Reference herein to any specific commercial product, process, or service by trade name, trademark, manufacturer, or otherwise does not necessarily constitute or imply its endorsement, recommendation, or favoring by the United States Government or any agency thereof. The views and opinions of authors expressed herein do not necessarily state or reflect those of the United States Government or any agency thereof. 


\section{DISCLAIMER}

Portions of this document may be illegible in electronic image products. Images are produced from the best available original document. 


\section{DISCLAIMER}

This book was prepared as an account of work sponsored by an agency of the United States Government. Neither the United States Government nur dny dyelly thereof, nor any of their employees, makes dily warranty, express or implied, or assumes any legal liability or responsibility for the accuracy, completeness, or usefulness of any information, apparatus, product or process disclosed, or represents that its use would not infringe privately owned rights. References herein to any specific commercial product, process, or service by trade name, trademark, manufacturer, or otherwise, does not necessarily constitute or imply its endorsement, recommendation, or favoring by the United States Government or any agency thereof. The views and opinions of authors expressed herein do not necessarily state or reflect those of the United States Government or any agency thereof. 


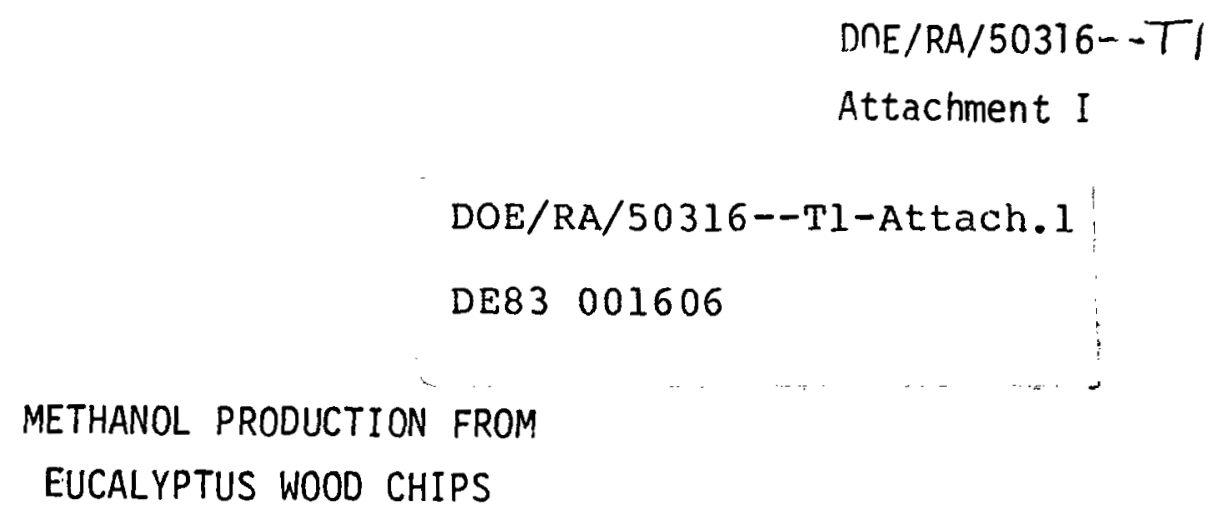

Working Document 1

The Florida Eucalyptus Energy Farm -

Silvicultural Methods and Considerations

Principal Investigator:
Henry H. Fishkind

Apri 1982

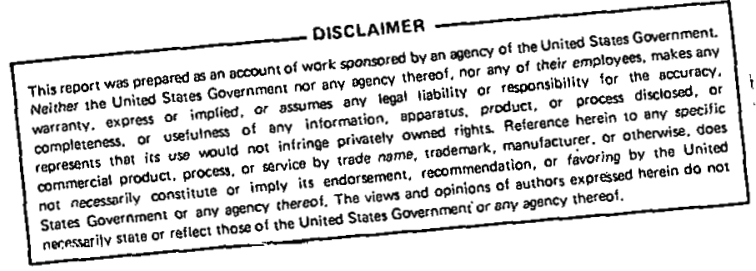

- HOTICE

PORTIONS OF THIS REPORT ARE ILIEGIBLE. It thas been reproduced from the best availablo copy to permit the broadest possible avallab1lity.

Prepared by

Biomass Energy Systems, Inc.

1337 Gary Road

Lakèland, Florida

For the

U.S. Department of Energy

Office of Alcohol Fuels

Under Grant No. DE-FG07-80RA50316 

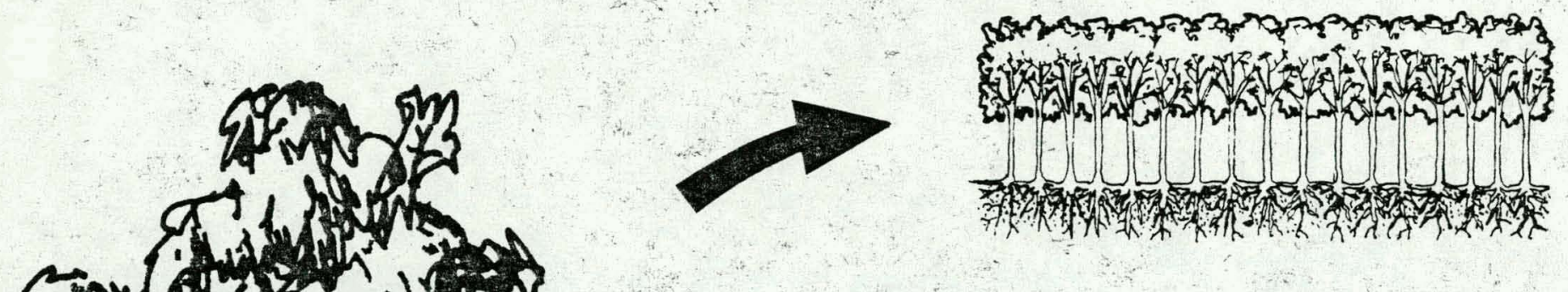

THE FLORIDA EUCALYPTUS ENERGY FARM--

SILVICULTURAL

METHODS AND CONSIDERATIONS
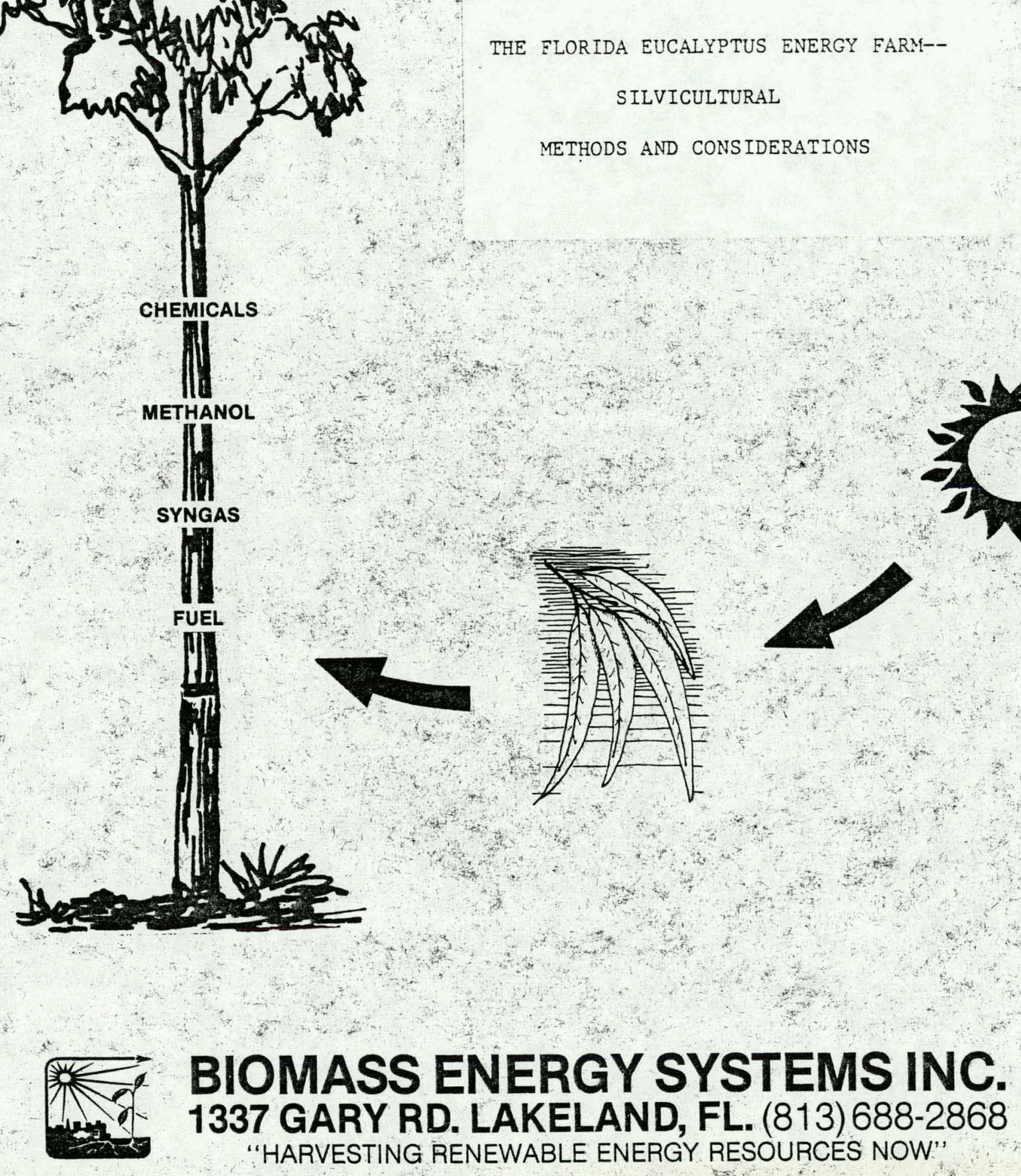
1.0 INTRODUCTION AND OVERVIEW 1

2.0 REVIEW OF PRESENT KNOWLEDGE AND THE LITERATURE 5

2.1 Biomass

2.2 The Wood Energy Plantation

2.3 Eucalypts as Candidate Biomass Trees

2.4 Eucalyptus camaldulensis--Our Species of Choice 14

2.5 The Eucalyptus Experience in Florida 16

2.6 Plantation Installation 25

2.7 Plantation Management $\quad 42$

2.8 Harvesting Issues $\quad 52$

2.9 Wood Markets for Florida Eucalyptus 60

2.10 Economic Feasibility 63

3.0 PLANTATION HISTORY $\quad 66$

3.1 Overburden Planting 66

3.2 Sand Tailings Planting 69

$\begin{array}{lll}4.0 & \text { SITE PREPARATION } & 75\end{array}$

$\begin{array}{lll}4.1 & \text { Background } & 76\end{array}$

5.0 PLANTING $\quad 79$

5.1 Climate $\quad 79$

5.2 Spacing and Density 92

5.3 Methodology 94

5.4 Seasonal Considerations 97

5.5 Air Quality 98

5.6 Native Vegetation as an Indicator of Land Suitability for Eucalypts $\quad 99$

6.0 SPECIES SELECTION 103

6.1 Eucalypt Suitability 103

6.2 Monocultural Containment 104

$\begin{array}{ll}6.3 \text { Propagation } & 105\end{array}$

7.0 MAINTENANCE AND MANAGEMENT 112

7.1 Fire Protection 112

7.2 Vegetative Competition 114

7.3 Disease/Insects 116

$\begin{array}{lll}7.4 & \text { Grazing } & 117\end{array}$

$\begin{array}{ll}7.5 \text { Wildife } & 117\end{array}$

$\begin{array}{lll}7.6 & \text { Cold } & 118\end{array}$

$\begin{array}{lll}7.7 & \text { Drought } & 119\end{array}$

$\begin{array}{lll}7.8 \text { Access } & 119\end{array}$ 
8.0 HARVESTING 121

8.1 Background 121

8.2 Wood Storage on the Plantation 124

8.3 Logistics of Delivering Wood to the Plant 127

8.4 Transportation Alternatives 128

8.5 Feedstock Ownership 130

8 Harvest Costs 130

$\begin{array}{ll}8.7 \text { Harvesting Methodology } & 131\end{array}$

9.0 EUCALYPTUS BIOMASS PRODUCTION ESTIMATES 133

9.1 Background 133

9.2 Projection 135

9.3 Weights and Volumes 135

9.4 Methanol Plant Feedstock Requirements 138

9.5 Estimated Costs, Yiplds, and Grobo Revenues 139

$\begin{array}{ll}10.0 & \text { SYNOPSIS } \\ & 142\end{array}$

Literature Cited $\quad 144$

Personal Communications 159

\section{LIST OF TABLES}

2-1 Potentially Available Biomass Production Lands for Five-County Area of Central Florida 22

3-1 Recent Growth Increase--Overburden 70

3-2 Recent Growth Increase-Sand Tailings 71

3-3 Soil Analysis and Recommendations--Sand Tailings 74

4-1 Examples and Price of Locally Available Site Praparation Equipment

5-1 Probable Freeze Dates

5-2 Percent Chance of Selected Rainfall Amounts per Week at Lake Alfred and Moore Haven 84

5-3 Historic Temperatures at Bartow and LaBelle, Florida 88

6-1 Volume comparison Using Two Variables 106

6-2 Analysis of Select Sprouting--Felled VS Wounded 110

9-1 Preliminary Eucalypt Growth and Energy Projections 134

9-2 Tree Weights (Green) 136

9-3 Estimated Daily (Per Ton) Operating Costs for Whole Tree Harvesting 140

9-4 Estimated Daily (Per Ton) operating Costs for
Whole Tree Chipping 
2-1 Important Eucalypt Plantings in Florida 17

3-1 Polk County Location Map-Agrico and Grace

$$
\text { Plantations }
$$

5-1 Freeze Probabilities

5-2 Southwest and West-central Florida C1imates 87

5-3 Mercator Projection

5-4 Example of Plantation Design 93

5-5 Vegetation Map of Study Area 100

5-6 Land Use Map of Study Area 102

8-1 Tons of Water as Moisture Content Decreases 125

8-2 Cubic Feet Increase as Moisture Content Decreases 126 


\subsection{INTRODUCTION AND OVERVIEW}

Biomass Energy Systems, Inc. (BESI) launched its wood-to-methanol project in 1980 on parallel tracks, assessing the feasibility of both a 100 MGY methanol refinery and a 100,000 acre eucalyptus energy plantation to provide an assured and constant feedstock for the methanol refinery. This document describes in considerable detail the silvicultural matrix within which the nation's first large scale wood energy plantation will be nurtured into reality.

Wood biomass is the oldest energy system employed by man, and wood remains the primary subsistence fuel for much of the world's population. Wood biomass energy is the most environmentally benign of all the large scale energy systems and has an ecological soundness absent from the fossil fuel systems. Fundamentally, it is a solar technology where the leaf is the collector of solar energy which it converts and stores in the form of cellulose via photosynthesis. Wood and its byproducts are converted into energy and conventional fuel equivalents by combustion, gasification, pyrolysis, methanol synthesis, fermentation, or a combination of these processes.

When the OPEC cartel embargoed petroleum shipments to the West in 1974 , they triggered a severe change in energy supply and demand balances, intensified by a second crunch in 1979. These changes in the world energy matrix rather suddenlyhave made wood fuel technology economically competitive with fossil fuels, especially coal and foreign petroleum distillates. Thus, what is new about today's wood biomass technology is the scale of wood fuel production necessary to meet exploding market demands.

An unbiased reviewer of the literature on wood fuels and related topics would conclude there is an explosion of interest and activity which will impact heavily on the wood production industry and economy in the near term. The National Audubon Society projects the use of biomass as fuel to increase from 2.1 to 8.9 quads by the turn of the century, with more than half of the increase attributable to wood. Some 7 million wood stoves have been sold in 
the United States over the past three years. The wood products industry supplies most of its energy from wood, while many other industries are converting rapidly their boilers from fossil fuels to wood whenever a nearby wood source assures a dependable fuel supply. Electrical utilities are converting to wood on a small scale, wood supply and delivery systems being the primary retardant. The wide interest in methanol as a gasoline additive and neat fuel has interested a number of companies other than BESI in woodto-methanol systems. Indeed, Evergreen Energy Corporation, a consultant to BESI, is launching a pilot project to convert the Texaco coal gasification system to a wood feedstock. International Harvester has entered the field with smaller scale, skid-mounted, wood-to-methanol plants which move to the wood source rather than transporting the wood to a larger plant. The foreign market for wood chipe has never been better in price or demand. Thic tip of the iceberg sketch of expanding demand leaves little room for doubt that highly productive silvicultural energy plantations have a bright economic future in a market where demand will far exceed supply for the next several decades. Bioenergy programs must be designed to exploit the unique regional resource base. Because of the favorable climate and available lands, florida south of Orlando is perhaps the most ideal region within the United States for creating a new, large scale wood energy system. Forest planting is a land use highly compatible with the increasing human population which characterizes Florida's growth. The "organic" appeal of a renewable energy source from trees should result in public and political support, in contrast to the attitudes toward strip-mining for example. Environmental protection fervor may reach its zenith in the Central and South Florida region.

A eucalyptus energy plantation, with 871 trees to the acre, each a cloned replicate of a proven superior parent tree, growing in the Florida sunshine and rainfall, has a potential yield of hardwood fuel which far exceeds man's experience with most other natural or planted forests. Some eucalypt species have an astonishing ability to convert sunlight, water, and nutrients into stored energy. Individual E. camaldulensis, the river redgum in Australia, planted on mined lands in Polk County have grown to 90 feet in height and 14 inches in diameter in less than seven years! One measured tree added $10 \%$ in 
volume during the winter months between December 1980 and March 1, 1981; a period of expected slow growth and cold temperatures. Our mensuration studies of this existing stand show a yield of 15 cubic meters per hectare per year, about one-sixth of the estimated potential production of intensively managed, cloned eucalypts planted on better sites under more favorable growing conditions. This ability of eucalypts to rapidly produce such a great volume of wood fuel with virtually no management costs between planting and harvest, makes them the outstanding candidate tree choice wherever the climate and environment permits.

Establishment of additional woodlands is an environmentally desirable alternative to pasture and row crops, particularly on soils marginally suitable for agriculture. The installation of comercial wood fuel plantations is the only, economically viable means of increasing forest acreage in the region. Although wood fuel plantations cannot compare with undisturbed native forests in biological values; they are ecologically benign compared to other more intensive land uses in Central and South Florida. In fact, fuel production forests still provide many of the benefits attributable to natural forest ecosystems--soil and water conservation, air quality improvement, climatic control, wildlife habitat, and esthetic and visual enhancement. Furthermore, wood fuel systems offset the adverse environmental effects of alternative fossil fuel systems.

The regional abundance of available and suitable lands is crucial to the development of a large scale, wood fuel system. There are well over a million acres of suitable land that might be converted to an energy plantation use. A comitment by landowners must occur before plantations can be established. Educating landowners to the exploding demand for wood fuel is necessary before they will incur the cost of installing the energy plantation. Most of the present land-uses are of a low intensity/profitability and will be easily displaced by uses with higher economic returns. The dominant present use is for cattle grazing, primarily cow/calf operations, an industry under severe economic stress. 
Wood energy plantations will provide their owners with a profitable land use, while generating extensive socio-economic benefits to both the region and the state. Energy plantations are a potentially large and profitable industry for Central and South Florida. They will create substantial employment, service and other income opportunities. Furthermore, biomass plantations are one of the few ways in which the region and Florida can produce extensive amounts of energy. By moving towards a national energy self sufficiency, a Florida wood energy system can make a substantial economic and strategic contribution. The opportunity is great, the timing is right, and a vigorous wood fuel industry is aborning in Florida. The first large scale silvicultural energy plantation was started in 1982 with the deliberate planting of eucalypts in Polk County as an energy crop. That beginning will expand through the 1980's into hundreds of millions of eucalypts from which the first wood fuel can be harvested in 1988. There will be no halting of this idea whose time has come. From the genetic pool contained in the almost invisible eucalyptus seed will spring a massive energy crop that translates into millions of tons of coal not burned in Florida, and millions of barrels of foreign petroleum products not consumed by Floridians. Let the planting begin so the harvest may soon follow to the benefit of Florida and her peoples. 
This section identifies and distills the relevent literature we have reviewed, as well as inserting key concepts and extant knowledge not necessarily documented in the literature. Rather than taking a bibliographic approach, we've concentrated on those ideas important to the evolution of our planned approach to the installation, management and harvest of the nation's first large scale Eucalyptus energy plantation. The work of others has contributed significantly to our project, for which we are grateful. Many of the ideas first presented here will be discussed more fully in later sections of the document.

2.1 Biomass. While the term biomass has an ecological origin as the total accumulation of biological material on a unit of area, the energy and fuels usage generally applies to agricultural and food wastes, animal wastes, organic municipal refuse, and crops specifically grown for energy uses. Biomass is a significant worldwide energy source and now supplies an estimated two percent of United States energy (Tillman, 1978).

The contribution of biomass to U.S. energy consumption in all its forms in 1979 was about 1.9 quads, the equivalent of about one million barrels of oil per day (Klass, 1981). Various projections for the year 2000 place the biomass share of total U.S. energy consumption at 10 to 20 percent, about onehalf of which will be contributed by wood waste and fuelwood. Increasing activity in many countries document that the processing and use of biomass is in transition toward a much larger role in bioenergy (Abelson, 1980).

Triggered by the high cost of petroleum and uncertain supplies, the massive use of biomass as chemical feedstocks is on the near horizon and may prove to be even more practical than a direct energy use (Budiansky, 1980). other woody biomass uses include raw material supplies for the pulp and paper industry, poles and pilings, plywood, furniture, construction, and a myriad of other applications. Additionally, biomass is widely perceived as an attractive thermoelectric energy source, especially as an alternative to coal and the atom for the production of power (Plotkin, 1980).

The potential for a new technology based on terrestrial biomass systems recently was assessed by the MITRE Corporation (Johnson, et al., 1980), including a comprehensive analysis of methanol production from feedstocks grown on silvicultural farms. A 1979 symposium sponsored by the Division of Petroleum 
Chemistry of the American Chemical Society (1981), entitled Biomass as a Nonfossil Fuel Source, is a must beginning point for all students of biomass fuels.

2.2 The Wood Energy Plantation. Wood fuel is the biomass technology with the greatest near-term capability to displace significant amounts of petroleum consumption. Market forces now favor increased residential heating, electrical generation, and industrial uses of wood fuel systems. The U.S. Forest Service estimates that wood could supply 9.3 quads of energy for the nation annually, or about 12 percent of total consumption (Berger, 1981). With the widespread application of agroforestry technology, we consider this a conservative estimate.

The characteristics and value of wood as an energy resourch has been reviewed by Tillman (1978). While there is a great diversity among wood fuels, the better hardwoods have a Btu value comparable to lignite coal ( $\pm 8500 \mathrm{Btu} / \mathrm{lb}$ ), with the advantages of low ash, very low sulfur content, and a generally significant reduction in the combined environmental impact of combustion when compared to coal and petroleum. Disadvantages in the use of wood as a fuel are related to the high moisture content of green wood requiring drying or combusting in a mix with fossil fuels, larger volumes required for equivalent heating values, transportation and handling costs, localized supplies, and competition for the wood resource resulting in supply-side shortfalls. Clearly, expansion of the woody biomass resource base is necessary before substantial increases in wood energy uses can occur without disrupting the existing forest product industry (Berger, 1981). Only in a few localized areas of the United States are waste wood supplies and non-commercial forest stands available in sufficient quantity to sustain major increases in energy uses.

Trees can be successfully grown on marginally productive agricultural lands. Federal and state assistance programs encourage and support tree farming. Recently enacted tax incentive programs benefit tree farmers whose trees provide not only woody biomass, but a number of environmentally beneficial services.

A new agroforestry technology is evolving to mass produce wood fuel at greatly increased rates and yields (Inman, 1977; Mariani,et al.; 1978; Yang, et al., 1977; Howlett and Gamache, 1977; Sajdak, et al., 1981 and Ledig, 1981). While showing great promise, these high rate and yield wood energy production systems have been limited to research and development scale projects rather than becoming operational in the private sector. 
Wood fuel use in the Third World countries has been highly destructive to natural forest communities due to the lack of silvicultural management practices and natural limitations, such as the infertile, highly leached soils of the tropics or the thin soil of mountain areas. These lands are being deforested for a variety of reasons, including logging, slash and burn agriculture, cattle grazing, cultural expansion, and wood harvesting for fuel. Consequently, extensive research on fast-growing exotic trees has progressed considerably in countries like Brazil and the Congo. The major impetus to develop intensive forestry has been to reduce cutting pressure on less accessible native forests and improve energy and timber resources (Barney, 1980). In a drive to reduce the national trade deficit, Brazil has planted large industrial Eucalyptus plantations on deforested lands; consequently, wood pulp exports have increased five-fold in three years (Cameron, 1980).

Indeed, agroforestry programs in the Third World have far outstripped efforts in the United States (Spurgeon, 1980).. For over three decades, large scale Eucalyptus energy plantations have operated. in Argentina and Brazil to provide charcoal for steel mills (Mariani, et al., 1978): More recenty, Brazil has comitted other Eucalyptus plantations to gasification and methanol production in pilot plants.

A stable supply of woody biomass is essential for any planned, largescale comercial use of wood fuel. Silvicultural energy plantations can outproduce conventional forests many fold in their annual yield of wood feedstocks. Over most of the country, these woody biomass production systems must be installed if wood fuel is to realize its potential as an energy resource. For this to happen, the private sector must be convinced that high yield silvicultural plantations are profitable and economically sound investments before a significant installation of plantations can occur.

Sajdak, et al. (1981: 30-31) and Howlett and Gamache (1977:5) have identified a number of advantages of high yield, short rotation silvicultural plantations over conventional managed forests:

1. Higher yields per unit of land area; therefore, less land needed to produce a given amount of biomass.

2. Early amortization of plantation establishment costs.

3. Increased efficiency of most cultural and harvesting operations because of complete mechanlzation.

4. Reduced plantation regeneration costs after the first rotation. 
5. Genetically improved trees can be utilized quickly.

6. The biomass produced will be of more uniform quality.

The use of fast growing hardwoods for maximum biomass production continues to receive major emphasis. Several biomass candidate hardwoods have been tested in the United States, including red alder (DeBell, et al., 1978), cottonwood (Baker and Blackman, 1977), poplar (Zavitkovski, 1979), sycamore (Steinbeck, et al., 1972) and eucalypts (Conde and Rockwood, 1979). Tree improvement programs are producing genetically improved plant materials, with strains being developed for specific soil and site conditions. Gains in yield from advances in genetics and vegetative propagation are being matched by gains from more intensive plantation management.

"Intensive culture", as defined by Dawson (1976), is the "application of several cultural practices to the establishment and management of plantations with the objectives of increasing the quantity and quality of wood produced." This includes the practices of silviculture, pathology, genetics, and economics, collectively. To be economically viable, the Eucalyptus energy plantation concept requires a high level of biomass productivity. This argues for a closely spaced, short-rotation silvicultural regimen. However, the degree of silvicultural intensity used in cultivation will have a marked effect on economic feasibility as well as productivity.

Biomass productivity potential under close-spaced, short-rotation conditions is estimated to range from 5-13 dry ton equivalents (DTE) per acre per year with current technology (Inman, 1977; Bungay and Ward, 1977; Fege, et.al., 1979). Berger (1981) reports preliminary yields from optimum research sites of 12 to $30 \mathrm{dry}$ tons per hectare per year, while sites not subject to improved management conditions have shown yields of 5 to 8 dry tons per hectare per year. Other DOE test sites have shown 25 to 90 percent production improvements from first generation genetic selections.

Rapidly growing trees, like those in the Eucalytpus stands we have studied, allow for lower establishment costs per acre becase of the lower stocking densities typical of conventional forest plantations, while achieving high yields, short rotations, and regeneration by coppicing. This combination of the above listed advantages of silvicultural energy plantations, the unusual potential of eucalypts to rapidly produce biomass, the favorable Florida climate, and the availability of large acreages of suitable land hold the promise of economical and feasible large scale wood fuel plantations. 


\subsection{Eucalypts as Candidate Biomass Trees. Eucalyptus is one of}

the fastest growing tree genera, and is used extensively in reforestation around the world (Food and Agricultural Organization of the U.N., 1975). The genus includes between 450 to over 700 species, sub-species and/or varieties, depending upon the taxonomic source (Kr ugman, 1974; Mariani, et al., 1978; Blakely, 1955; and Johnston and Marryatt, 1965). The eucalypts are broad-leaved evergreen trees within the myrtle family (Myrtaceae) that range from tall trees bigger than the redwoods to low growing shrubs. While eucalypts are mainly native to Australia, where they dominate about 95 percent of the forest areas, they also are native to the Philippines, New Guinea, Timor, and Indonesia (Hal1, Johnston, and Marryatt, 1963; Hall, Johnston, and Chippendale, 1975).

The adaptability of many species of eucalypts to a wide range of environmental conditions is well documented (Mariani, et al., 1978; Chippendale, 1973; Hillis and Brown, 1978). In Australia, they occupy deserts and rain. forests, snowy mountain slopes to infertile sands, salt flats to rich loams, swamps, and virtually all habitat types between the extremes. Members of the same species often grow under very different environmental conditions (Boden, 1964.

This extreme adaptability and genetic plasticity, as well as the rapid growth of medium denisty hardwood with excellent fiber characteristics (Penford and Willis, 1961), has led to their introduction and cultivation over much of the world with favorable temperatures, including southern Europe, the Middle East, Africa, India, Pakistan, South America, and North America. Worldwide plantings of Eucalyptus, over the past two centuries, probably exceed a million acres. This is a tree crop with which man has had a great deal of cumulative silvicultural experience reported in a vast technical literature. Probably, only the tree genus Pinus has been more studied.

Eucalypts were first introduced into California and Hawaii around 1853 (LeBarron, 1962; Penford and Willis, 1961) and Florida about 1878 (2on and Briscoe, 1911). Other states with eucalypt plantings include Arizona, Georgia, Mississippi, Texas, and Washington (Mariani, et al., 1978). About 
200 species of eucalypts have been introduced into the United States, mostly as ornamentals (Rrugman, 1974). Most recent large scale plantings by commercial interests have been in Florida, where pulp and paper companies have sought a suitable low cost hardwood fiber crop. Since 1977, consideration of eucalypts for biomass plantations has focused on programs in Hawai, California and Florida.

A compreshensive feasibility study was completed in 1977 which analyzed the biomass potential for candidate tree species under shortrotation plantation regimes in different geographical locations. This study, entitled Silvicultural Biomass Farms, was prepared for the United States Energy Research and Development Administration (now the Department of Energy) to assess the potential of wood biomass as a feedstock for producing energy products (Inman, 1977). Eucalyptus was identified as the primary biomass candidate for Florida (Howlett and Gamache, 1977). Mariani, et a1. (1978) expanded on the potential of eucalypts for silvicultural energy plantations. Even in Australia, there has been a gradual evolution from management of the natural eucalypt forest to eucalypt plantations in which productivity has increased enormously through the application of agroforestry techniques developed in Spain, Portugal, and South America (Cromer, 1974). Clearly, the worldwide trend is toward highly productive plantations of eucalypts; mechanized; intensively managed; planted with either genetically select, or cloned trees; all within a reasonable transportation distance of an industrial facility that makes full utilization of the harvested trees.

The most important single criterion for selecting tree candidates is simply the ability to grow rapidly in total biomass (Howlett and Gamache, 1977). This includes characteristics such as: (1) rapid juvenile growth; (2) adaptability to varying site conditions; (3) ease of establishment and regeneration; and (4) freedom from major insect and fungal pests.

A number of eucalypt species are adapted to relatively frost-free locations in the continental U.S. Attacks of insects or disease are uncommon, and no significant amount of damage has been observed in this country (Schory, 1960; Uhr, 1976; Mariani, et al., 1978). In addition, Inman (1977) predicts that a biomass production of 12 dry ton equivalents per acre per year is feasible with existing technology utilizing the close-spacing, short-rotation philosophy. 
Bevege (1976) has suggested a practical upper limit dry weight yield of 50 tons/ha/yr for woody crops. Silvicultural expectations of normal yields from well-managed eucalypt plantations of superior trees exceeding 20 dry tons/ha/yr appear reasonable for warm temperate and tropical regions. Yields of clonally propagated Eucalyptus at Aracruz Cellulose, S.A. in Brazil currently average $65 \mathrm{~m}^{3} / \mathrm{ha} / \mathrm{yr}$, which is equivalent to about $11 \mathrm{dry}$ tons/acre/ year. Their best clonal plantations have reached maximum yields of almost 14 dry tons/acre/year. Small, sample plots of eucalypts in certain favorable sites in East Africa and Brazil have grown at a rate of $90 \mathrm{~m}^{3} / \mathrm{ha} /$ year, or 15.5 tons/acre/year (Eldridge, 1978). Conversely, an excellent slash pine Florida plantation might accrue wood at a rate of $16.1 \mathrm{~m}^{3} / \mathrm{ha} /$ year, or only 2.3 tons/acre/year. Maximum biomass yield from eucalypts in Florida is undeterminable at present, although the preliminary evidence from existing stands in Polk and Glades Counties suggest a potential range in production:consistent with eucalypt plantations elsewhere in the world.

Yang, et al. (1977) evaluated the Eucalyptus energy plantation .. scenario and concluded that Eucalyptus was a particularly desirable biomass. crop for Hawaii. They concluded that eucalypts had about the same solar energy conversion efficiency as grasses, and that a sustained growth of 10 feet in height and one inch diameter each year had been demonstrated in existing stands. Sizeable acres of mature (65+ years) eucalypt stands are cut and chipped annually for export to Japan for paper pulping. These mature trees exceed 200 feet in height and 40 inches d.b.h. The nature of Hawaii's eucalypt forests have been described by Picford and LeBarron, 1960; LeBarron, 1962; Walters, 1980; and Fujii, 1976. Yang, et al. (1977:6-87) identified the following advantages and disadvantages of Eucalyptus biomass plantations in Hawai:

- rapid growth and good yields are attainable on non-agricultural land with little or no cultivation

- extensive plantings are present in Hawaii indicating adaptability to soil and climate conditions

- no problems concerning insect or fungal pests have arisen in the 70 years Eucalyptus has been planced in Hawaii 
- cut stumps coppice repeatedly and regenerate very rapidly-coppices several feet high at six months after cutting and 20 to 50 feet tall after two years were observed at Paauilo Mauka, Hawaii, on Capitol Chip operating sires*

- harvest technology is quite well developed and exemplified in Hawaii by the Capitol Chip operation; most costs are readily available

- chips produced could be marketed for pulp or for energy, if economic conditions so indicate

- mechanized planting technology exists and is feasible for Hawaii

*On-site observation by task force member.

Vail (1979) conducted an interesting study screening woody plant candidates for biomass plantations within the United States, resulting in 24 likely candidates, of which Eucalyptus was one. Vail considers woody biomass as one of the most promising alternatlve energy sources, but cautions that its renewability must be preserved by optimizing the productive utilization of natural resources (sunlight, water, and nutrients) to maximize biomass supplies.

The ideotype technique (Donald, 1968) is applied to describing the following biomass crop ideotype (Vail, 1979:8):

\section{(1) Processes Solar Energy}

- Upright, excurrent growth and multilayered crowns to efficiently capture sunlight on any given spot

- Indeterminate growth, early growth initiation, and long leaf retention to collect sunlight over as much of growing season as possible

- Perennial above-ground stems to provide easily accessible storage of biomass

- High Specific Gravity - for maximum storage of energy per volume of biomass 
(2) Responds to Man's Manipulation

- Narrow, compact crown and steep branch angle to allow close spacing

- Coppicing habit to allow multiple harvests from a single planting

- Rapid juvenile growth to allow short harvest cycles

- Early successional stage to allow maximum use of inorganic nutrients and sunlight 
The Eucalyptus spp. with the greatest potential for biomass crops score extremely well on all of the above eight characteristics. As a cropping system, eucalypt biomass plantations combine high productivity with greater stability than agricultural systems of similar yields. Management maintenance requirements between harvests are likewise minimal. This is why BESI has selected eucalypts as their plants for woody biomass production. The established quality of Eucalyptus fiber for pulping is a strong secondary factor assuring a non-energy secondary market.

\subsection{Eucalyptus camaldulensis--our Species of Choice. In the fall of} 1980, BESI by necessity selected a single species to work with initially in its Dentral plorida plantings. We deijled un $E$. camaldulensis, lie tives ted gum, for the following reasons:

1. It is the most widely distributed eucalypt in Australia, naturally occuring along streams and in Eloodplains (Hillis and Brown, 1978).

2. It is known for rapid growth on poor sites with low rainfall.

3. The ability to tolerate periodic waterlogging of soils and high soil salinity, as well as drought.

4. It coppices readily, with plantations in Israel already in the seventh cutting cycle.

5. The usefulness of the wood for fuel, including a high density.

6. One of the most widely planted exotic species, especially in the Mediterranean area, with about 500,000 ha of commercial plantations established.

7. Achieves its best stem form under dense stocking conditions; and normally does not require intensive management (fertilization, irrigation, and pest control).

8. A dozen or more studies from around the world, like Siddiqui, et al. (1979) for Pakistan, spoke of E. camaldulensis being physiologically more adaptable to a variety of environmental and managed conditions than the other species of Eucalyptus. 
9. California screening of 36 species by King and Krugman (1980) placed $E$. camaldulensis among the seven highest rated species for survival and growth, especially after the record-breaking 1972 freeze. Resistance to freeze damage is an extremely important characteristic for Central Florida plantings.

10. Historically, circa 1910, the largest eucalypt in Florida was a river red gum growing near Fruitville, and there were larger numbers of this species in more places in Florida (Zon and Briscoe, 1911) than any other. These authors also considered the species resistant to temperatures as low as 18-190F after the first yer of growth.

11. Emphasis elsewhere in Florida on research with $E$. robusta and $E$. grandis and their hybrids, suggesting the value of prioritizing research on a third species.

12. Data availability from seven year old stands of $E$. camaldulensis already established in Polk County on mined and reclaimed soils, including the knowledge they had survived the local climate prevalent during that period.

13. The existence of "superior" trees in these Polk County stands from which we could obtain juvenile sprouts for tissue culture experimentation and production-scale propagation.

14. The apparent inability of this species to produce an abundant and viable seed crop in South Florida helps to address environmental concerns about escape and natural system invasion, neither of which was evident for this species in our field studies.

15. Demonstrated resistance to disease, insect pests, and catasrophic fire. 
2.5 The Eucalyptus Experience in Florida. Several species of eucalypts were planted on Merritt Island, Florida, as early as 1878 (Zon and Brisco, 1911). Important experimental plantings: are reported as early as 1942 by Claude Devane, Tropical Forestry Project, Florida Forest Service. Additional experimental plantings were made in 1954, and the results were so encouraging that Eucalyptus research was given a higher priority (Schory, 1960). During this early period, The Tropical Forestry Project began to coordinate activities with the U.S. Forest Service, the Florida Forest Foundation, the Plant Introduction Gardens, the Fairchild Tropical Gardens, and the Subtropical Experiment Station (Metcalf, 1961). Also during the mid-1950's, several pulp and paper companies such as the Buckeye Cellulose Corporation, the St. Regis Pulp and Paper Company, and the Collier Corporation initiated experimental plantings of Eucalyptus on their Florida owned lands (Mariani, et al., 1978). A cooperative research and development program involving the U.S. Forest Service, the Florida Division of Forestry, and several comercial firms was established in 1971. The Southeastern Forest Experiment Station of the U.S. Forest Service has a continuing research program to improve eucalypts. Species selection, site conditions, and cultural practices for pulpwood production have been the major thrust of the research. Recent efforts by the Forest Service and the University of Florida have begun to explore the potential of eucalypts as a biomass resource.

2.5.1 Existing Plantings. The generalized locations of the major eucalypt plantings in Florida are shown in Figure 2-1. The Florida planting program was described in considerable depth by Uhr (1976). The Florida comercial eucalypt acreage has increased from nearly 3,000 acres in 1976 to almost 18,000 acres in 1982, mostly Georgia-Pacific Corporation and Lykes Brothers, Inc. plantings in Glades County. These stands of $E$. arandis and $E$. robusta have been severely stressed by two extreme droughts in 1980-81, followed by a hard freeze in January of 1982. The extent of recovery from these combined stresses will be monitored closely in the sumer and fall of 1982 . The emphasis on the florida eucalypt program thus far has been fiber production, rather than as an energy crop. There is a growing interest in the energy potential of the Florida eucalypts, as well as the possibility of launching a Florida eucalypt chip export industry and researching the pulp properties of Florida grown eucalypt wood (Franklin, 1977). 
The production potential of Fiorida eucalypts has been considered by Conde and Rockwood (1979), relying on E. grandis data from Meskimen and Franklin (1978). The pulpwood plantings are seriously understocked at about 300 trees per acre, resulting in a low production level of less than $3 \mathrm{DTE} / \mathrm{A} / \mathrm{yr}$ (Conde and Rockwood, 1979). We believe estimates of production levels presented in this document more closely approximate the probable yield from a Florida eucalypt energy plantation.

Much of the Florida research consists of unpublished data not available to us at this time; and, of course, the research is ongoing. Meskimen (1979:2. revised 1980) summarized growth and yield data from Lykes Bros., Inc.'s Ferguson Forest:

- An 8-year seedling rotation

- Trees averaging $18+m(60$ feet $)$ tall at age 8 years

- Perhaps a 7 year coppice rotation

- Two, perhaps three, coppicè rócations

- Yields in the range of:

Pessimistic - $13 \mathrm{w}^{3} / \mathrm{ha} / \mathrm{yr}(2.2 \mathrm{dry}$ tono/acre/year)

Realistic target $=16 \mathrm{~m}^{3} / \mathrm{ha} / \mathrm{yr}(2.5 \mathrm{dry}$ tons/acre/year $)$

Optimistic $=19 \mathrm{~m}^{3} / \mathrm{ha} / \mathrm{yr}(3.0 \mathrm{dry}$ tons/acre/year $)$ 
Meskimen cautions that gross understocking was the overriding characteristic of these three stands. Freeze dieback has been the primary condition defect in the Ferguson Forest, affecting 22 percent of the trees.

Meskimen and Franklin (1978) recommend a spacing for $E$. grandis plantations of 6 feet by 12 feet, with a density of 605 trees per acre. This planting, at age 5 months, froze back to the ground with a minimum temperature of $23^{\circ} \mathrm{F}$ five feet above the ground. Despite the freeze, survival was 92 percent at 4 years and 85 percent at 7.4 years. Genetically improved seedlings were used from second and third generation seed orchards. The authors predict a rotation of $8-10$ years and at least two coppice rotations before the need to replant.

Geary (1975) experimented with December and February winter plantings in Collier County, Florida. The obvious efficiencies of winter planting are an important consideration in establishing large acreages. The four species tested were $E$. camaldulensis, E. tereicornis, $E$. grandis, and E. robusta. Almost 100 percent of the seedlings of all species survived the December planting (dry conditions). In the February planting (exceedingly $d r y), 86$ percent of $E$. camaldulensis and $E$. tereticornis seedlings survived contrasted to 38 percent of the $E$. grandis and $E$. robusta. This is consistent with $E$. camaldulensis being more drought resistant as well as more cold hardy than $E$. grandis or $E$. robusta.

There has been extensive unpublished experimentation with the application of rock phosphate, resulting in the current Glades County practice of applying 0.5 tons per acre to the beds after site preparation. A trend has been observed of moderate improvement in cold hardiness with the application of rock phosphate on some sites. 
A major emphasis in the Florida eucalypt program has been on achieving genetic gains (Franklin and Meskimen, 1973; 1975). A very promising line of $E$. grandis $\times E$. robusta $F_{1}$ hybrids has resulted from this work (Franklin, 1978). Rockwood and Squillace (1981) have reviewed the potential of utilizing genetic differences in woody feedstocks to increase yields of methanol and ethano1. Rockwood and Conde (1975) are conducting research on genetic variation in $E$. grandis as it relates to biomass production, particularly the response to competition effects at denser spacings.

The most recent review of genetzc selection of eucalypes, largely in Florida, has been provided by Franklin (1978). Franklin emphasizes the need for genetic adaptation of virtually any eucalypt seed lot to the Florida environment, by selection and breeding, before the species or provenance can be adopted to form comercial stands. This poses severe constraints on the planting of large acreages with high yield $E$. grandis and $E$. robusta seedlings in the colder areas of Central Florida. Vegetative propagation by cloning of high quality parent trees of $E$. camaldulensis growing in Polk Councy remains the most viable near term alternative source of plants in large numbers until other cold hardy, fast growing species and yruveuaütes become available on the long term after undergoing the genetic selection procedures described by Franklin (1978). 


\subsubsection{Land Suitability and Availability. Numerous authors}

have stressed the need for available land acreages before a sufficiently large wood energy system can be installed (Inman, 1977; Howlett and Gamache, 1977; Mariani, et al., 1978; Johnson, 1980). The available lands and their current uses have been described in our Background Environment Document, relying heavily on data provided by the Environmental Protection Agency in their areawide impact assessment of the Central Florida phosphate industry (EPA, Vol IV and Vol $X, 1978$ ). This Silvicultural Document also addresses the available land questions. The Economics Document contains a comprehensive evaluation of available land from a real estate perspective. A regional land suitability analysis by BESI shows over 320,000 hectares (nearly 800,000 acres) of prime eucalypt lands in the region. Over 550,000 acres (nearly 225;000 ha) are owned by a handful of phosphate companies alone, largely committed to a ranching use. The total acreage available for energy plantations in Central and South Florida probably approaches two million (more than 800,000 ha).

Salo, et al. (1977) evaluated the land potential for silvicultural energy plantations for four land scenarios, using the USDA Soil Conservation Services' land classes, with the most available lands being noncroplands in Scenarios 1, 2 and 3. Available lands ranged from a low of almost 7 million acres (nearly 3 million ha) in Scenario 1 to 15 million acres (over 6 million ha) in Scenario 3 (Table 2-1).

Clearly, an abundance of land is available in uses that have a low economic return to the owners and to local governmental taxing authorities. The projected productivity of Eucalyptus plantations will make them economically competitive with most other agricultural uses of the land resource. 
TABLE 2-1

Potentially Available Biomass Production Lands For Five-County Area of Central Florida

\section{Land Quality in Acres (Hectares)}

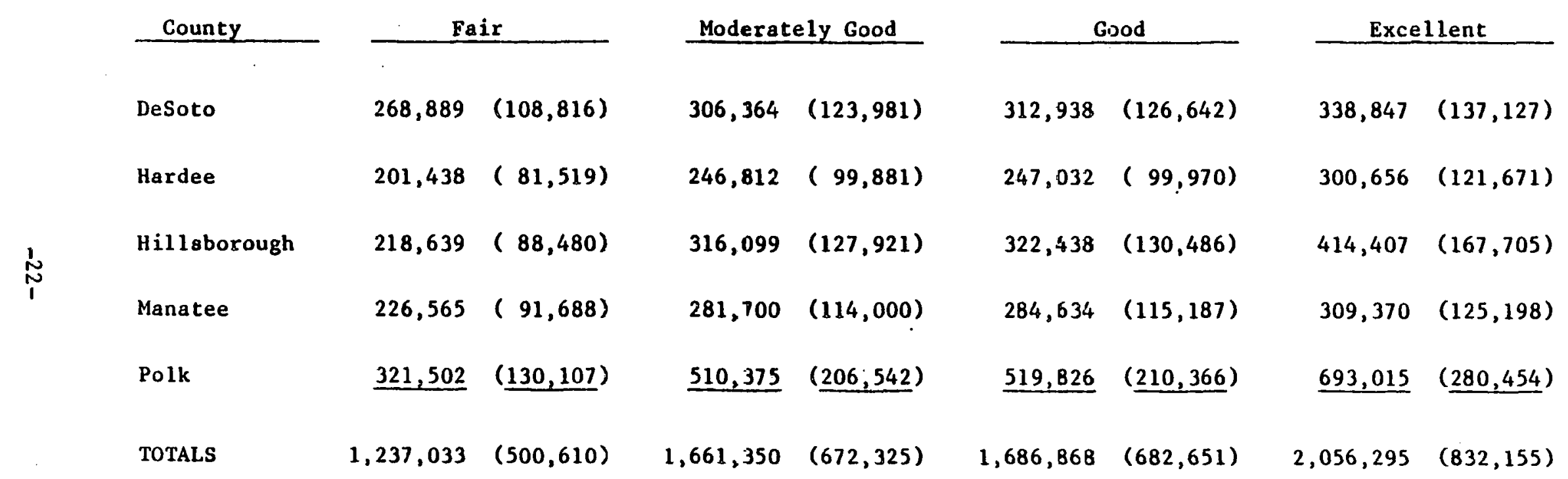




\subsubsection{Climatic Suitability. A complete evaluation of}

regional climate is provided in the Background Environmental Document. The climatic suitability of the region for growing eucalypts is discussed in Section 5.1 of this document. Salo, et al. (1977) identified Eucalyptus spp. as a possible biomass candidate for their North Florida site in Levy County, expressing the view that cold tolerant species could survive the winter freezes. The major problem with growing eucalypts anywhere in the Southeast is the problem of damage or death caused by cold weather. Genetic selection of cold hardy species and tissue culture propagation of individuals surviving hard freezes eventually will provide eucalypts for plantations in North Florida. At this time, BESI does not recomend commercial plantings of eucalypts north of Polk County. The damage caused by the 1982 freeze to the Glades County plantations reinforces this opinion.

Using the methodology of Papadkis (1970) and the world climatic diagrams of Landsberg, et al. (1965), climatic comparisons are possible between the Florida study area and Australia. Over half of the weather stations in Australia record minimum temperatures comparable to peninsular Florida (Mariani, et al., 1978). Prevailing temperature conditions are suitable for eucalypt plantations in the study area, as is visibly demonstratable by the eucalypts growing throughout the region. However, cold hardiness differences in yields and survivability between species, provenances, and even clonal lines can be of major economic importance for the commercial planting. All eucalypts are most vulnerable to freeze damage during the first few months after planting. A hard freeze of long duration could devastate a newly installed, or even two year old plantation, especially if the plants are not from a cold-hardy line.

Moisture is an equally important limiting factor, especially during the first few months after planting. Only drought tolerant varieties should be planted between February and June in the winter drought/sumer rainfall cycle common to the study area. The winter planting experiment of Geary (1975), 
in which February was extremely dry, resulted in over 60 percent mortality of the $E$. grandis and $E$. robusta. Generally, the study area is in the moist, sub-humid climatic type of Watts' (1971); and the 55-60 inches of annual rainfall is sufficient for high yield eucalypt production, probably with a preference for drought-resistant lines.

The Australian towns of Atherton, Bowen, and Rockhampton in northeastern Australia have climates (Landsberg, et.al., 1965) similar to Tampa, Florida. This is the natural range of $E$. camaldulensis from which additional provenances will be selected for Florida test plantings.

Ultimately, field performance is the only positive verification of a eucalypt's suitability for a particular climate. This is the primary reason why BESI has relied on a Spanish provenance (unknown) of $E$. camaldulensis that has performed well in the Polk County climatic matrix. As a species, E. camaldulensis is considered to be more drought tolerant and cold hardy than most other eucalypt biomass candidates. 
2.6 Plantation Installation. Vast acreages of presently nonproductive or underproductive Central and South Florida marginal lands can become Nature's storehouses of solar energy through photosynthesis and woody biomass growth. They are available and awaiting the installation of eucalypt energy plantations. The scarcity of available, suitable land has been considered by many to be a limiting factor for large-scale wood production (Tillman, 1977; Zavitkovski, 1976, Inman, 1977). Typically, the land resources of a region are committed to other, often more economically productive land uses. In some areas, large landowners have the option of directing future land utilization. The presence of the Phosphate Industry in West-central Florida has resulted; in a relatively few ownerships, each with large acreages of available lands suitable for eucalypt plantations. Cattle grazing is the predominant pre-mining and post-reclamation land use. Beef production potentially is vulnerable to displacement by a more productive land use, such as eucalypt biomass:plantations .

The establishment of wood producing plantations in Florida historically has been in areas immediately adjacent to industries with a large and continuing consumptive appetite for wood. Most plantation production is targetted for an identifiable market at the time of establishment. The wood producing capabilities of Central and South Florida have been underutilized because of the long distance from an established market and associated high transportation costs. Productivity generally has been lower, also, because of poorer site quality and climate for the tradirional southern timber species. Most of the land was in open range until the 1950's, lacked statewide fire protection until the 1970's, and continues to lack a ready local market for the wood produced. High land values, low yields and prices, and long distances from markets continues to discouage all landowners except for the most foresighted. The eucalypt energy plantation concept merges new marketing opportunities within the region with a tree crop that can produce high yields on marginal land at a profit. 
Because the direct cash cost of initially installing the plantation is high ( $\pm \$ 500 / a c r e)$, few landowners will make the investment on large acreages until the uncertainties of the market place are lowered. There are no silvicultural limitations or technological obstacles to installing eucalypt plantations on a scale of 20,000-30,000 acres per year. The economic uncertainties and up-front cash requirements are the actual limitations we encounter in each conceptual presentation to landowners. As the establishment of eucalypt plantations moves forward, experimental observations and new data will contribuce to the melliviology reported in the literature and in this dacument. 


\subsubsection{Site Preparation. Site preparation is the treatment}

of land to place it in a condition to grow most abundantly the woody . biomass crop. Complete site preparation is essential to the control of competition in the first year (Schory, 1960). Seedlings, once suppressed, never fully recover from the effects of competition even if they survive. Conversely, initial growth increases obtained during the early establishment phase as a result of intensive and complete preparation are maintained during the entire rotation (Schonau, 1977; Schonau, et al., 1980). Virtually all authors agree on the overriding importance of complete site preparation and we are convinced of its necessity. Sites with prohibitive preparation costs should not be committed to a eucalypt plantation. Once the established seedlings achieve canopy closure or site dominance, in Florida between 12-18 months post planting, control of competition is no longer a problem (Carter, 1974).

To achieve complete preparation most sites must be deep plowed and cultivated. Thorough cultivation results in spectacular initial growth rates (Luckoff, 1955). Groulez (1970) had similar results in Mediterranean plantations. Obviously, methods and costs vary significantly between a pasture site and a well-stocked woodland (Yang, et al., 1977).

Site preparation overlaps with planting since the type of planting machine employed may require modifications in the preparation technique (Cameron and Riley, 1981). Relationships with fertilization have also been demonstrated (Meskimen, 1971), where fertilizer treatment partially compensated for grass competition. A relationship with fire risk is evident in that the highly vulnerable eucalypt plantlets are at little risk on new sites where the ground cover fuel accumulation is minimal as a result of complete site preparation and/or the use of herbicides. The length of time to canopy closure or site dominance by the planted eucalypts also is a function of the density of the stocking; a spacing interaction. High soil moiscure is important to establishment 
during the first days following planting, and the elimination of competing plants helps to retain soil moisture for the eucalypts, as well as nutrients, "minerals and trace elements.

Generalized approaches to site preparation have been considered by most planners of silvicultural biomass plantations (Salo, et al., 1979). These generally consist of clearing, chopping, disking, the application of such soil amenities as ash and fertilizers, the installation of roads, irrigation and drainage systems, etc. Decisions as to which treatments to use are highly site and crop specific. For example, bedding is a common and necessary treatment in the South Florida eucalypt plantations on the palmetto prairie sites (Cowan, in $\mathrm{ms}$ ); but, it is not needed for the most well-drained, sandy sites of Central florida. Large plantations will need to be sub-divided into forest management modules dependent on differences in soil, hydrology, and topography. Planning of the biomass energy forest is a necessary first step before the onset of site preparation. 


\subsubsection{Planting Stock. There is temendous variability}

in Eucalyptus growth due. to genetic differentiation (Uhr, 1976).

Although there are many outstanding trees in eucalypt stands, there is little consistency in height and diameter at breast height (dbh) among the individuals in a stand. Knowledge of the breeding systems of various eucalypts has been well reviewed by Eldridge (1978) with suggestions for genetic improvement. Many, probably most, plantations originate from a few seed trees, resulting in an inadequate genetic base for the establishment of large plantations. This problem is particularly acute in terms of the Florida seed source for the $E$. camaldulensis used in our program. Jackson and Oio (1973) have shown that the Petford and Katherine provenances ( $S .6953$ and S.6860) from northern Australia gave excellent results in Nigerian field trials. To improve the genetic base for $E$. camaldulensis requires provenance trials in Florida. BESI places a high priority on obtaining seed lots from northern Australia collected from a large number of widely separated, select trees. Trees from these collections, grown in Central Florida, will then be selected for tissue culture propagation to produce the many millions of plantlets needed for a 100,000 acre energy forest. We recognize the necessity to seek a continuous improvement in biomass tree characteristics by the deliberate broadening of the genetic base. The best provenances of any Eucalyptus species must be screened for those natural qualities that best fit the man-dominated enviroment of the Florida energy plantation.

The initial source of our $E$. camaldulensis clonal plantlets for the first plantations must be from select trees in the existing polk County stands. Preliminary experience has shown that the plantlets propagated from the highest quality trees in the stands reflect the vigor and dominance of the parents. 
Hartney (1980) offers a comprehensive discussion of vegetative propagation of eucalypts, including tissue and organ culture. Krugman (1974) reviews the North American experience with the production of eucalypts from the seed. We agree with his observation that vegetative propagation from cuttings and grafting does not appear to be practical in the United States. Low labor costs are essential for a cutting system to be economically feasible. Likewise, there has been only 1 imited success with bare-root Eucalyptus plantings. Consequently, nearly all ', commercial florida plantings involve small, containerized seedlings 
adaptable to machine and hand planting. With the acceptance of a standardized container, automated or semi-automated planting equipment will be perfected. Plantings in Florida usually occur from mid-June to mid-September, although winter planting has been tried with variable success (Geary, 1975).

The Florida Division of Forestry is the primary supplier of commercial Eucalyptus seedlings in Florida. The seedlings are propagated at the Division's Herren Nursery from available quantities of select and unimproved seedlots. According to Herren Nursery staff, production has concentrated more on Eucalyptus grandis and $E$. robusta than other species. These two species exhibit exceptional growth, although they are sensitive to freezing temperatures. Other species that have been utilized include E. camaldulensis, E. tereticornis, and E. viminalis, which are considered candidates for colder climes. Eucalyptus camaldulensis seems particularly promising in Central Florida.

Seed progeny testing for South Florida continues to improve seed stock (Franklin and Meskimen, 1975), although it takes many years to develop superior strains from seed. During 12+ years, Florida eucalypt seed sources consistently have been improved. However, open, uncontrolled pollination continues to result in a wide range of genetic variation in seedlings, and thereby restricts potential improvement. Seeds from the current progeny testing have been producing more uniform stands and currently are in commercial use (B. Swendsen, pers. comm.). Selection has concentrated on fast juvenile growth, as well as form and volume of harvestable loge.

The first select seed: from Florida orchards became available for nursery production in 1972. Even today, procuring large quantities of select nursery stock requires lead times of eighteen months and longer depending on the quantity required. The further improvement of genetic strains, selection for adaptability to Central Florida, selection for productivity on mined soils, and large scale production of superior planting stock are of paramount concern for the accuation of a comercial wood energy system in the study area. 
BESI has elected to concentrate on the establishment of plantations with cloned plantlets for the following reasons:

- Reduce Genetic Variability. Most Florida eucalypts originate with containerized seedlings, nursery grown, from select seed orchards. Even when the seeds are from select mother trees subjected to several generations of genetic improvments, plantations show dramatic variability, particularly in wood volume. In a six year old plantation, two inch dbh trees commonly are found growing next to twelve inch dbh trees from the same seed lot. Cloned plantlets replicate the form of the original parent tree, resulting in a more uniform stand with much greater productivity. We project a minimal doubling of woody biomass yield if cloned plantlets are installed rather than seedlings.

- Improve Growth and Form. The efficient growth, harvest and transport of fuel wood to market requires uniformity and optimization of such traits as diameter, height, straightness of stem, crown size, branching, etc. By selecting carefully for these characteristics the donor trees to take into tissue culture, plantlets are produced that mirror the outstanding qualities of the parents.

- Adaptation to Site Specific Conditions. Plantlets can be grown in a controlled environment and subjected to stressful ambient conditions or soils modeled after the plantation site. Plantlets surviving such exposures are more likely to survive when outplanted to the site. Tolerance to high salinity, high or low soil moisture levels, and low temperatures can be established rapidly chough the uoc of tissue culture technology.

- Numbers. The rapid multiplication rate achievable in the tissue culture laboratory is the only technology available for producing the large numbers of select eucalypt plantlets needed for a 10,000 acre plantation without delaying the planting for two or more years. 
- When weighed against the increased yield and the one-time planting cost for multiple harvests, the substantially higher cost of plantlets in contrast to seedlings is economically sound. 


\subsubsection{Planting Considerations. The experience in planting}

eucalypts of other workers relevant to our concept is limited, because no one has planted large numbers of clonal plantlets produced by tissue culture, in Florida or elsewhere. Since these clonal plantlets are much more expensive than nursery seedlings, $\$ 300 / 1,000$ versus $\$ 80 / 1,000$, the cost alone demands that each plantlet be given an optimum opportunity to survive and produce a high yield of woody biomass. Thus, extreme care must be taken at each stage of the planting process.

A low soil moisture coupled with high evapo-transpiration conditions (hot, sunny, and windy) would be life threatening to racently installed plantlets, as would a hard freeze. Therefore, until there is more experience in Central Florida, plantings should take place in the six months between June 1 and October 31. Watering-in of the plantlets normally would not be economically feasible, nor would irrigation. The selection of eucalypts resistant to drought and freeze effects is, the most practical approach, while acknowledging the risks of weather and climate inherent in most cropping systems.

The large areas to be planted and the high costs of labor compel the use of mechanical planting machines. Because of the emphasis on complete site preparation on favorable topography, we intend to use the continuous furrow concept (USDA-Forest Service, 1967), probably with monual feeding at the first stage of operatfons. Tlit factors relating to mechanical planting systems have been reviewed recently by Lawyer and Fridley (1979). Our automated nursery production system in Todd Planter Trays (Speedling, Inc.) is compatible with a continuous furrow planter. The 10 foot spacing between rows prohibits the multiple row mechanical planters now on the market. Again, because of the high cost of the plantlets, the biological factors affecting survival and vigor override the speed and efficiency of the plancer. 
Cowan (in ms) recommends a planting depth 2-4 centimeters below the soil line of the container. Deep planting is especially important under low soil moisture conditions (Schory, 1960). Root placement, shoot orientation, and soil compaction around the root mass are parameters crucial to survival and vigor, as well as the depth of planting. A mechanical planting system will have to be fine-tuned to handle our plantlets and containers (Lawyer and Fridley, 1979). However, most of the commercial Florida eucalypt acreage has been planted by machines designed for planting bare-root-pine seedlings. We do not believe the selection or development of a suitable planting system will be limiting in any way.

As emphasized by Cowan (in ms), at least two weeks should pass between site preparation and planting; but, site prepared land should not go unplanted indefinitely because of the speed at which competing plants invade the site.

The transportation and handling of the plantlets between the nursery and the site must be well organized and done in such a way as to not disturb and stress the plantlets. Soil moisture, controlled temperatures, proper ventilation, and minimal time for planting after removal from the nursery are controlling factors (Cowan, in ms). The Todd Planter Trays provide a nearly ideal system for maintaining a high quality of plants during transition.

Plantlets must be protected from cattle grazing and fire during the first year following installation (Schory, 1960). Density and spacing considerations are addressed in the following section. 


\subsubsection{Planting Density and Spacing. Numerous studies in}

the U.S. have documented spacing and rotation experiments of various short-rotation candidates including poplar, red alder, and sycamore (Steinbeck and McAlpine, 1972; Ek and Dawson, 1977; DeBell, et al., 1978; and Kennedy, 1975). The data can be correlated directly to Eucalyptus cultivation only in general terms. Extremely dense plantings ( $1^{\prime} \times 4^{\prime}, 2^{\prime} \times 4^{\prime}$, etc.), once considered optimum for energy plantations, are not considered economical for northern hardwoods (Rose and DeBell, 1978). Recent dense plantings of Eucalyptus grandis in California have produced yields of $10 \mathrm{dry}$ tons/acre/year and may prove eoonomical to cultivate (Sachs, et al,, 1980). Data from high density eucalypt plantings in South Florida by the University of Florida and the U.S. Forest Service are currently being collected. High volumetric yields are reported by most authors when spacing is reduced and the number of plants per acre is increased. In nearly every case, high density plantings suffer a higher plant mortality. Harms and Langdon (1976) report various densities for Loblolly pine (Pinus taeda L.) ranging from 1,012/acre $(2,500 / \mathrm{ha}$ ) to $16,187 /$ acre $(40,000 /$ ha $)$ with plant mortality at age 14 ranging from less than $20 \%$ for the lowest density to more than $75 \%$ for the highest density. Sachs, et al., (1980) reports high yields from Eucalyptus grandis planted in Southern California at a spacing of about 2.5 feet by 2.5 feet $(75 \mathrm{~cm} \times 75 \mathrm{~cm})$, a density of $6970 \mathrm{trees} /$ acre $(17,222 / \mathrm{ha})$. Wardle (1967: 47) concludes that "the spacing giving the best financial resules depends on the precise objective of the enterprise: and that "on the expectations considered most likely to come about, spacing of 8 feet gives the best financial result."

A study of Eucalyptus saligna for saw timber in Hawaii compared results of 15 year-old plots planted on $14 \times 14,12 \times 12,10 \times 10$, and $8 \times 8$ foot spacings (Walters, 1980). A striking result was that the mean annual volume increment peaked at 5 years for all spacings. Total stem volume at 15 years ranged from 9759 cubic feet per acre (i.e., $7.8 \mathrm{dry}$ tons/acre/ year) for the $8 \times 8 \mathrm{ft} .(2.4 \times 2.4 \mathrm{~m})$ spacings to 7096 cubic foet/acre (i.e. $5.5 \mathrm{dry}$ tons 
acre/year) for the $14 \times 14 \mathrm{ft} .(4.3 \times 4.3 \mathrm{~m})$ spacing. Other spacing trials with Eucalypt in South Florida have suggested that if merchantability limits on tree size were circumvented, yields 16-68 percent greater could be achieved at close spacings (Meskimen and Franklin, 1978a). However, it is apparent that doubling the stocking, from 577 to 1147 trees per acre, does not double the volume production after 7.4 years. Neither optimum rotation age or spacing have been evaluated for eucalypt energy plantations in Florida (Conde and Rockwood, 1979). Wang, et al. (1981) reported on experimental Eucalyptus energy plantation at LaBelle, Florida installed on a $1 \times 1 \mathrm{~m}$ spacing that required 10,000 plants/ha. They assumed a planting cost for 10,000 eucalypts of $\$ 50 /$ ha $(\$ 20: 23$ /acre $)$.

Several coppice harvests are anticipated with some stool mortality with each harvest. Since interplanting following establishment is not a recommended practice, the initial stocking rate needs to be high enough to compensate for both wortality of plantlets or seedlings and the loss of stools. Biomass Energy Systems, Inc. intends to stock its plantations with tissue cultured plantlets at 871 trees/acre on $5 \times 10$ foot centers $(1.5 \times 3.0 \mathrm{~m})$, thereby allocating 50 square feet $\left(4.5 \mathrm{~m}^{2}\right)$ to each tree without compensating for mortality.

Meskimen and Franklin (1978) concluded that Eucalyptus grandis in Florida planted at a spacing of 4 feet by 8 feet $(1.2 \times 2.4 \mathrm{~m})$, a density of 1361 trees/acre (3354/ha), yielded a volume about 1.7 times greater than a planting 8 feet by 12 feet $(2.4 \times 3.7 \mathrm{~m}$ ), a density of 454 trees/acre (1122/ ha). These authors recomended a $6 \times 12$ foot spacing, or 605 trees/acre $(1495 /$ ha $)$ until more data becomes available. Higher density plantings of almost any woody biomass species produce higher volumes at harvest. In most cases diameters are smaller and, at a species dependent age, stem height levels off. Most high density plantings have been done on very small acreages, usually hand planted, and many have not considered the economic return when compared to the initial establishment cost. Costs must include not only the plants, but also planting, and maintenance to the point of harvest. Harvesting efficiency is very much a function of density and yield. 
Harvest yields below 40 tons/acre ( 90 tonne/ha) are not likely to be cost effective (JPR Assoc., 1981). Can we plant high density stands of 43,560 trees/acre $(110,000 / \mathrm{ha})$ on 1 foot centers by machine? Is proven harvesting equipment available? In today's money market, can the grower afford plant costs of more than $\$ 3,000$ per acre (almost $\$ 9,000$ per hectare) at start-up? Where plantlets produced in tissue culture cost several times the price of seedlings, the number of trees planted per acre becomes the dominant cost in establishing the plantation. 


\subsubsection{Fertilization. The use of commercial fertilizer}

on forest land as a management practice has been limited in scope and largely experimental (Motley, et al., 1980). Whole tree biomass production with higher densities and shorter rotations results in higher attendant requirements for nutrients (Riekerk, et al., 1981). One reason for fertilization of biomass energy plantations, other than increasing yields, is to offset possible drastic reductions in nutrient availability and recycling efficiency which may accompany the frequent harvest of biomass and export from the site of nutrients andminerals (Lugo, 1970; Barnett, 1981). Applications of coal and wood ash industrial wastes, usually with single rotation applications following harvests, as well as forest land disposal of treated waste waters, sludge and solid waste mulches, are possible soil treatments.

Yearly fertilization of the LaBelle Eucalyptus Site has been at the rate of $50 \mathrm{~kg} / \mathrm{ha} /$ year of nitrogen and phosphorus on a 10,000 trees/hectare stand (Smith and Conde, 1980). Cowan (in ms) has recommended even applications of $\frac{1}{2}$ to 1 tonne/hectare of ground rock phosphate on the site-prepared land, followed by passing a bedding plow with an hourglass roller to firm beds. This one nutrient treatment per rotation has become the standard management practice for eucalypt planting in Glades County, Florida, with visually obvious favorable results when contrasted to untreated control areas. The use of phosphate fertilizer on poorly drained flatwood soils in Northwest Florida sometimes resulted in increases in wood accumulation of $700 \%$ (Laird, 1972).

The relationship between eucalypt growth performance and applications of nitrogen and phosphorus are complex and defy generalization as reviewed by Cromer, et al. (1980). As might be expected, research results are highly variable, depending largely on the species, treatments, soil and moisture conditions, and climate. 
Eucalypts have produced phenomenal amounts of biomass with the application of more intensive silvicultural practices. Under the proper conditions, fertilization can increase productivity 3- to 5-fold (Cromer, et al., 1975; Cromer et al, 1980). Hartley (1977) had good results with fertilization trials of $E$. tereticornis in Papua New Guinea, as did Krohn (1981) in Guam. Until more research is available, BESI intends to rely on site specific soil analyses before deciding on nutrient supplements, other than the standard provision of $\frac{1}{2}-1$ ton/acre of ground rock phosphate on all but mined'soils which may require a nitrogenous treatment to offset atypically high phosphate levels. Fertilization is an expensive, energy intensive subsidy that should be utilized only when research and experience demonstrates its necessity and cost-effectiveness.

Weed control during the early establishment phase is considered one of the main restrictions to initial growth (Schonau and Boden, 1980) which overrides fertilization effects. Meskimen (1971) reported on the value of inhibiting effects on $E$. camaldulensis of competition with turf grasses. Mycorrhizae can be important to eucalypt nutrition (Pryor, 1956; Malajczuk, et al., 1975); but, we know of no study of this relationship in the Florida eucalypt plantations. 


\subsubsection{Weed Control and Herbicides. The need for control}

of competing plants in the early life of the plantation has been well established in the literature and discussed in this document. Thorough site preparation and extensive cultivation have been the primary approach

in eucalypt plantations rather than the application of herbicides. A long acting, postemergent herbicide that was effective, safe and inexpensive would be enormously helpful (Martin, in press). Wang, et al. (1981) report that the use of herbicides to control weeds in Eucalyptus plantations is unknown. Apparently, none was used in the LaBelle planting (Smith and Conde, 1980). Sachs, et al. (1980) used a preemergence herbicide in their very dense plantings of $E$. grandis but thought it may have been unnecessary because of the near total domination of the site by the foliage of the biomass crop. Wattle crop growers in South Africa are enthusiastic over the use of glyphosate at the rate of $300 \mathrm{ml}$ per sprayed kilometer to control inter-row weeds. Because of damage to the eucalypt crop, a spray rig dubbed the $C$. D. Wricksha was developed to prevent spray drift onto the wattle rows (Wattle Research Institute, 1981).

As with fertilization, the effectiveness and methodology for chemical control of weeds in eucalypt plantations are highly site and species specific, including selection of the best herbicide for the specific situation. Until we have experimented with a variety of materials in field trials, BESI does not intend to routinely use herbicides for plantation establishment. Herbicides have not been a standard management practice in the Glades County plantings. We estimate the cost of a single herbicide application to be $\$ 40 /$ acre $(\$ 100 / \mathrm{ha})$. 


\subsection{Plantation Management. The foremost eucalypt plantation}

management questions address irrigation, rotation cycles, fire hazards, and pest damage. No soil amenity treatment or fertilizer applications are anticipated except at site preparation and possibly following harvest.

\subsubsection{Irrigation and Water Relationships. Under normal} eucalypt plantation management regimes, BESI considers irrigation an unnecessary economic cost, and a needless consumptive use of water. It is neither practical or feasible to install a system. Rarely, cropland with existing irrigation systems may go into eucalypt production. This would allow dry season planting free of plantlet mortality from water deficit stress. Existing irrigation systems also would provide the opportunity for experimentation to determine if appreciable growth increases can be realized by irrigating during periods of inadequate rainfall. Wilting of established eucalypts has not been observed by us in Central Florida, even during the severe droughts of 1980 and 1981 .

Eucalyptus species vary in their transpiration rates, as shown by Raul and Negi (1979) where E. saligna had 1.5 to 2.0 times the water loss of E. tereticarnis. E. tereticornis demonstrated an effective stomatal closure mechanism lacking in the other species tested which resulted in a dramatic decrease in transpiration when challenged by a water deficit stress. Since $E$. camaldulensis is known to be drought hardy, it probably has a similar mechanism to maintain a favorable water balance. E. tereticonnis also had a lower stomatal frequency, an adaptation that permits a higher level of hydration under water deficit stress conditions. This type of research needs to be done on Florida grown $E$. camaldulensis. Because of genetic determinants, differences in drought resistance can be expected between provenances of the same species. A low energy management strategy dictates selecting eucalypts that are drought resistant rather than practicing irrigation. 
Karschon and Heth (1967) studied for 4 successive years the water balance of an $E$. camaldulensis plantation in Israel on a semiarid site with a mean rainfall of $640 \mathrm{~mm} /$ year. They determined the ratio of actual evapotranspiration by the trees to open water evaporation as 0.06:0.11 for the average over the dry season. Thus, the leaf was practicing a significant conservation of water when compared to free water evaporation. Often, Florida's hardwoods have evapotranspiration losses greater than pan evaporation. Soil moisture depletion by a grove of $E$. occidentalis growing on a desert site in Israel was reported by Stibbe (1975). As soil moisture declined, the quantity of water lost by evapotranspiration was sharply decreased. The actual evapotranspiration of the grove was 48 percent of pan evaporation, with an average rate of $8.6 \mathrm{~mm} /$ day over a period of 5 months.

Riekerk, et al. (1981) have measured a consistently lower soil moisture content under the "high density plantations" of eucalypts in South Florida. when compared to adjacent palmetto prairie. They estimate that transpiring forest vegetation in Central Florida consumes $15 \mathrm{~cm} / \mathrm{yr}$ of soil moisture, and, that eucalypts may exceed that rate. Frank Cowan (pers. comm.) has indicated that irrigation is not necessary for the eucalypt plantations in Glades County. However, these stands apparently were stressed by the record droughts of 1980 and 1981 . The intensive planting of eucalypts at the LaBelle site was assumed to require $25 \mathrm{~cm}$ of irrigation water per year in excess of rainfall (Wang, et al., 1981). Salo, et al. (1979) estimated irrigation system installation costs of over $\$ 1,000 /$ acre. Even if drought. periods result in a reduced rate of biomass production, it is doubtful that irrigation could be cost effective.

There are many complex interactions between irrigation, rainfall, and climate (Stidd, et al., 1975; Shukla \& Mintz, 1982). Massive replacement of semi-arid grasslands and deserts with forests can be expected to increase rainfall on a regional basis. There are equally complex interactions between the water table, forests, and nutrients, as discussed by white and Pritchett (1970); and, there are substantial hydrologic benefits from forests 
in controlling erosion and stabilizing sediments (Ursic and Duffy, 1972). Such interactions as they relate to eucalypt plantations are unstudied subjects for future research programs.

Irrigation of energy crops has been proposed as a means of creating optimum conditions for maximum yield. Some research indicates a tentative conclusion that energy invested in producing biomass will bring commensurate increased returns (Zavitkovski, 1979). However, this probably is not a judicious alternative in Central Florida considering the high cost and relatively ample water hudget, unless high nutrient waste water from phosphate operations or sewage treatment plants is utilized. Rose and Rallstrom (1976), in their analysis of the esonomie feasibility of intensive cultures, suggest that irrigation costs might be charged to the cost of cleaning up polluted effluent. We believe this to be the only way in which irrigation systems could be affordable for eucalypt plantations. In locations where mining companies are required to operate under a zerodischarge regulatory dictum, as in the watershed of Lake Manatee, the waters normally discharged could be used to irrigate biomass crops grown on both reclaimed and unined land. 


\subsubsection{Rotation Cycle. Several studies in the U.S. have}

documented spacing and rotation experiments of various short-rotation biomass candidates including Populus spp., red alder and sycamore (Steinbeck and McAlpine, 1972; Ek \& Dawson, 1977; DeBell, et al., 1978; and Kennedy, 1975). The data cannot be correlated directly to Eucalyptus cultivation, except perhaps in general terms. The optimum rotation age has not been evaluated for eucalypt energy plantations in Florida (Conde and Rockwood, 1979). With no economic constraints imposed, the optimum rotation age would be reached when mean annual biomass growth rate truncates or levels out (Zavitkovski, 1976). However, fiscal considerations, especially land costs ard high interest rates, could reduce the optimum economic rotation, possibly to a lesser age than that set by the growth rate of the trees.

Harvests need to occur when the rate of biomass accumulation declines, and/or when the trees reach the upper limit diameter near ground level for efficient mechanical harvesting, about 12 inches $(30 \mathrm{~cm})$. Our studies of Polk County $E$. camaldulensis stands show substantial increases in biomass through the 6 th year, with growth occuring in all seasons. Basal diameter of some select trees exceed the limits of conventional harvesters at year 7. Stems need to be cut (sheared) near the ground to favor coppicing. Therefore, BESI has selected for planning purposes, 7 years as the optimum growth interval to first harvest. Subsequent intervals between coppice cuts might drop to as low as 5 years, depending on mensurational data which will be gathered in the plantations as on-going research.

Meskimen and Franklin (1978) anticipated a rotation of 8 to 10 years for Glades County $E$. grandis plantings. Franklin (1979) observed that $E$. grandis and $E$. robusta may have a potential for a 1 to 3 year rotation on the phosphate strip-mined lands north of the Glades County plantings. In South Florida's oldest eucalypt plantation, stand volume continued to 
increase through year 10; but, there was a substantial decline in the rate of volume increase after year 8 and height increases leveled out sharply at year 8 (Meskimen, 1979). The author's best guess projection for the Ferguson Plantation was an 8 year seedling rotation and a 7 year coppice rotation.

The choice of rotation is varied according to the planned use of the stand. Opie, et al. (1978) considers a short rotation as one less than 40 years! But Sachs, et al. (1980) were cutting their $E$. grandis biomass planting cwlce annually. Ethiopians cut their $E$. camaldulensis torest every 2 to 3 years (Horvath, 1968). Siddiqui, et al. (1979) note that $E$. camaldulensis provenances in Pakistan that were fast growing at age 6 were still fast growing at age 10, with no loss in specific gravity. Cromer, et al.(1975) found no drop in productivity over a 10 year rotation in an Australian intensive culture fertilization experiment. In a report from Portugal (Goes, 1967), rotations of 10 to 12 years were used for a variety of eucalypt species. The Hawaii terrestrial biomass plantation study group (Yang, et al., 1977) recommended 5 to 8 year rotations of eucalypts as the primary biomass crop. A 40,000 hectare eucalypt plantation in Brazil is harvested on a 7 year rotation cycle (Abelson, 1982). A study of $E$. saligna for saw timber in Hawaii compared results of 15 year-old plots planted on $14 \times 14,12 \times 12$, $10 \times 10$, and $8 \times 8$ foot spacings (Walters, 1980). A striking result was that the mean annual volume increment peaked at 5 years for all spacings.

The above cited literature supports selection of a 7 year first harvest rotation interval in an optimum regimen. There will be sufficient flexibility to cut at 6 years if economic factors dictate; or, to wait until year 8 if there is no need for harvesting in year 7. At this point, we would not recommend a rotation beyond year 8 . for a biomass use of the trees. 


\subsubsection{Fire Hazard. The threat of "catastrophic loss to}

wildlife is an uncertainty faced by most forest managers and woodland owners. Schory (1960) believed that all Florida eucalypt plantations must be managed to exclude fires. He noted that young plants are particularly vulnerable, and that a few species like $E$. robusta developed a thick protective bark as they mature. The coppicing trait of eucalypts permits revegetation of the stand, even when most of the trees are killed or severely damaged.

As Eucalyptus ecosystems mature, litter fuel accumulates to an equilibrium level of 10-15 tons per acre (Crane, 1972). With such fuel accumulations, fires usually are uncontrollable. Eucalypt barks act as fire brands, and their ribbony distribution along the trunk allows for the rapid spread of fire into the crown (Mariani, et al., 1978).

\section{Allelopathic effects in eucalypt ecosystems have received a} great deal of research attention (Ashton, 1962; DeBe11, 1970; DelMoral and Muller, 1970; and Mount, 1968). Where such effects are well pronounced, the density of understory vegetation is reduced, with a lowered accumulation of fuel. Fire behaviour in eucalypt forests was the subject of a mono-. graph by McArthur (1967). MeArthur (1968) notes that the eucalypts in general have a high tolerance to fire with adaptations that allow them to survive fires of high intensity. LeBarron (1962) stated that forest fires present no serious problem to eucalypt plantations in Hawaii. Cremer, et al. (1978) observe that fire vulnerability differs with the individual plant, the site conditions, the species, and the stand. Fire damage is not readily predictable ahead of the fire event. 
We believe that the density of 871 trees per acre, the short rotation period of 7 years, and the intensive site preparation planned for the BESI eucalypt plantations will minimize the risk of catastrophic wildfire. The high moisture content of young trees likewise mitigates against mortality from a burn. Nonetheless, prevention by exclusion will be our first line of defense. The primary, management expenditure between planting and harvesting-will be the annual maintenance of a system of firebreaks. Suppression of nearby conflagrations in cooperation with the Florida Division of Forestry will be a constant management function of the BESI forestry staff. We do not intend to practice prescribed burns at this time. Possibly, fuel accumulation on a stand by stand basis may support experimental controlled burns. Fire may be an effective management tool for use between rotations, following the harvest. Mineralization of the litter and slash well might enhance the coppice growth. This will be a subject of future research.

Spontaneous combustion in a hardwood chip storage pile of 50,000 tons was reported by Boggan (1977). Temperatures increase in wholetree chip piles to $140^{\circ} \mathrm{F}\left(60^{\circ} \mathrm{C}\right)$, which drives off moisture and improves fuel value (Motley, et.al., 1980). Because of the uncertainty surrounding the fire hazard of whole tree eucalypt chips, which may produce more volatile gases than native hardwoods, chip storage piles should not be larger than 10,000 tons (the larger the pile, the higher the internal temperature), and their internal temperature should be monitored closely. At the plant site chip storage area, a water sprinkling system should be available to lower internal pile temperatures if the heat buildup becomes hazardous. Ideally, eucalypt wood chip storage at the plant will be minimized until we have gained experience and better defined the problem. 


\subsubsection{Potential Damage from Disease and Insects. Mono-}

specific plantings of many species of Eucalyptus have produced high-yielding stands up to $40-50 \mathrm{~m}^{3} / \mathrm{ha} /$ year in contrast to $10-25 \mathrm{~m}^{3} / \mathrm{ha} /$ year in native Australian stands (Florence and Shepherd, 1975). A Brazilian plantation of 40,000 hectares produced 40 tons/ha/year in the third rotation and a target of 100 tons/ha/year appears reasonable (Abelson, 1982). The major difference between native and exotic stands is the relative absence of foliage damage to introduced eucalypts by disease or insects when compared with the same species in Australian forests (Heather and Griffin, 1978). In fact, the depressed growth and productivity of subalpine Eucalyptus in Australia has been attributed to continuous grazing by phytophagous insects (Morrow and LaMarche, 1978). In another example, Podger (1975) reports 106 forest insects attacking $E$. saligna in Australia. At present, there have been no serious infestations of Florida eucalypts in forest plantings. However, plant pest impacts on Eucalyptus spp. may increase as plantings are expanded in Central and South Florida. If a severe problem occurs, a pest control management strategy will have to be implemented.

Schory. (1960) wrote that attacks by insects and disease in Florida were uncommon, and that no significant damage had been observed and reported in the United States. LeBarron (1962) indicated there were no serious pests present in Hawaii's eucalypt forests; but, that it was an always present threat. Beetles have been a serious problem for eucalypts in North Africa (Brunck, 1975). Termites in many tropical countries have been known to kill large numbers of living trees (Pong, 1974; Greaves, et al., 1967; Momoh and Gibson, 1975). The extent of risk is difficult to assess. Introduced trees on favorable sites with suitable soil, climatic, and moisture conditions, often are suprisingly free of insect pests. This appears to be the case in Florida, California, and Hawaii. South African eucalypts are relatively free of insect and fungal attack except for two insects imported by accident from Australia (Green Heritage Comm., 1978). 
A wide variety of fungi can attack locally grown eucalypts, causing stem or root damage (Kuhlman and Barnard, in ms). Fungi of the genus Cylindrocladium are particularly widespread vectors of leaf blights, stem cankers or root rot in eucalytps. Diaporthe cubensis fungi is an important cause of stem cankers on eucalypts in Brazil and Surinam (Hodges, et al., 1979). Damage is most severe among trees less than 6 to 8 years old. Infections are commercially significant in Brazil, promoting research for tolerant genotypes. High rainfall in a tropical climate appars to be necessary for a severe uutbreak. Clitucybe labescens, comonly referred to as "mushroom root rot", has been reported to occur on several eucalypt species in Florida, although damage potential is undetermined. It is widespread in distribution and often associated with large, rotting stumps. Heat lesions commonly are found on Florida seedlings just above the groundline on sunny, hot sites.

Although widespread in Australia, eucalypt pest problems are uncommon in Florida. Young saplings are much more prone to damage than well-established trees. Cattle periodically graze and trample them, deer may browse them, and hogs root them up. There also may be occasional grazing by beetles on tender new growth. These problems when detected are local and have impact on productivity in large plantations. Rabbits have been a serious problem in eucalypt forests in Australia (Rolls, 1969; Crane, 1972). A variety of small rodent species have damaged newly planted seedlings in California, leading to recommendations for in soil, wire rodent barriers.. When subject to cattle use, all new plantations should be fenced to protect young trees from grazing, trampling, and rubbing (Schory, 1960). 
The potential threat of disease outbreaks in large monocultures is always present because of (1) monospecific composition-the extensive use of one select species, (2) reduced genetic diversity-characteristic of clonally propagated crops, and (3) low plant resistance-exotic species not adapted to pathogens in a new environment (Heather and Griffen, 1978). These points must be addressed more comprehensively prior to widespread eucalypt cultivation. Genetic selection in concert with clonal propagation can act as an effective check system for harmful pathogens. Plantations consisting of one or a few clones lack genetic diversity. This can be overcome by planting many clones, with the members of each clone spatially separated (Hartney, 1980).

BESI foresters do not consider the risk of damage to Florida eucalypts from insects, fungi, and other pests to be sufficient to impede establishment of plantations or significantly impair productivity. A high degree of managerial vigilence should detect damage early enough to combat the pest agent in most cases. This is clearly an area of concern that will require research and attention as more plantations are installed. 
2.8 Harvesting Issues. Accurately estimating harvesting costs, about $\$ 1500 /$ acre in 1981 dollars, is crucial to the economic feasibility analysis because they are the largest single expenditures in the eucalypt wood production system. Fortunately, these expenses are incurred just before sale of the wood crop, so they need be financed for a brief period of time, if at all. Mechanical harvesting requires very expensive heavy equipment and a skilled work force. With the rapid changes in the stateof-the-art technology, predicting the specific harvest systam to bo uocd in 1989-1990 is unnecessaly; while estluating the capital, labor, and operating costs of that system is speculative at best. We have found very little information in the literature specific to our questions about harvesting systems and methods, timing of the harvest, coppicing, the relationships between harvest techniques and coppice yields, and site preparation for the coppice rotation. 


\subsubsection{Harvest Systems. The procurement of wood from}

the forest for use as fuel, fiber, or food has evolved from harvesting entirely by hand to nearly complete automation and mechanization.

In many cases hand labor has been displaced by machines because of the increasing cost of labor, safety, the expense of workman's compensation insurance, and industry requirements for increased productivity.

Changes in silvicultural recommendations and forest management techniques have also dictated changes in wood harvesting systems. Closer spacing, improved seed lots, and clonal plantlets have increased the potential for per acre wood production. In Australia, a mechanized harvester reduces labor requirements by two-thirds as opposed to normal billet. operations (Cromer, 1975). Whole tree chipping provides a profitable use for forest lands previously considered unproductive (Butts and Preston, 1979). An extremely comprehensive discussion of whole tree chipping systems has been provided by the FAO (1976) and JPR Assoc. (1981). Continually moving harvesters are technically feasible (Kerruish, 1977) for harvesting short rotation eucalypts. Howlett and Gamache (1977) observed that trees larger than 4 inches $(10 \mathrm{~cm})$ in diameter at ground level would have to be harvested using a conventional whole-tree harvesting system or some modification thereof. Silage type harvesting systems may be applicable for stands less than 3 years of age.(Rose, 1976; DeBell and Harms, 1976). A short-rotation harvester could sever, chip, and relocate chips via a blower into a trailing van or wagon (Dutrow, 1971). Whole tree chipping, besides producing raw material, can also dispose of slash as an alternative to burning (FAO, 1976). Warren (1977) and Miyata (1980) offer guidelines for estimating fixed and operating costs of logging equipment. 
Among the highest harvesting costs using conventional systems that we encountered were $\$ 13.60 /$ ton ( $\$ 12.34 /$ tonne) in 1977 and $\$ 16.32 /$ ton ( $\$ 14.81 /$ tonne) in 1980 for whole-tree chips (Ga. Forestry Comm., 1980). A cost of $\$ 7.50 /$ ton ( $\$ 6.80 /$ tonne) for whole tree chips, excluding stumpage or transportation, was quoted by Morbark (1980). A range of costs was reported by Motley, et.al. (1980) from $\$ 7.70 /$ ton ( $\$ 6.99 /$ tonne) to $\$ 11.12 /$ ton ( $\$ 10.09 /$ tonne) for various harvesting systems. Lee Timber Company (pers. comm.) reported harvesting costs of $\$ 14.29 /$ ton ( $\$ 12.96 /$ tonne) for a pulpwood stick operation in South Florida. Another Florida logging contractor reported harvest costs of $\$ 10.00 /$ ton ( $\$ 9.07 /$ tonne), plus transportation, for a whole tree logging operation (J.A. Martin, pers. comm. )

Because of the wide range in harvesting expenses, BESI has chosen to use a $\$ 10 /$ ton ( $\$ 9.07 /$ tonne) cost. When equated against a projected harvest of 154 tons ( 140 tonnes) per acre, harvesting costs approximate $\$ 1500 / a c r e(\$ 3360 / h a)$. We believe that when the harvests are needed beginning in 1990, systems will be available that offer the eucalypt grower a profitability factor equivalent to that resulting from a $\$ 10 /$ ton ( $\$ 9.07 /$ tonne) present day cost.

For current planning purposes, harvesting systems utilized should be those of proven performance. As prototype systems are developed and ascertained feasible through field trials, consideration will be given to any equipment which increases productivity, lowers per unit production costs between the plantlet and the plant, and lends themselves to overall operational profitability. 


\subsubsection{Coppice Growth. The economic feasibility of short}

rotation woody biomass cropping depends upon reliable coppice regeneratian. This is particularly so because of the high initial planting costs of tissue culture plantlets. The use of plantlets would not be cost effective if they were not contributing to several harvests. Coppice growth, the ability of a species to produce shoots from cut stumps, eliminates the need for replanting the subsequent rotation; thereby saving several hundreds of dollars per acre. The ability to coppice differs among species and provenances within species (Opie, et al., 1978). E. camaldulensis is well known for its coppicing ability. Hillis and Brown (1:978) show a coppice growth stand of $E$. camaldulensis in Israel where the very impressive 5 year old sprouts (about 60-70 feet tall and 10-12 inches dbh) were the sixth crop from the original stump!

Only those eucalypt spccies with lignotubers, which carry food reserves and an abundance of accessary bud tissue, coppice readily (Cremer, et al., 1978) from the root. Epicormic coppicing from stems is highly variable. Coppicing allows plantations to survive fire, freezes, and floods; as well as harvesting. We observed that small, containerized seedlings of $E$. grandis and $E$. robusta, planted just a few days before a hard freeze in Polk County, Florida, coppiced rapidly from their base. Coppice regeneration is known to be highly variable by the season of damage and site characteristics, as well as by species, provenances, and individuals. Tissue culture propagation from coppiced stands not presently available to BESI will help us to optimize this exceedingly valuable adaptation.

Thinning of the original stands of coppicing species is generally detrimental (Cremer, et al., 1978); and we doubt that thinning of coppiced sprouts down to 2 or 3 per stump would be cost effective because of high labor costs. The greatest volume of wood in coppice rotations of $E$. saligna 
in Brazil resulted from leaving 2 or 3 sprouts to the stump (Couto, et al., 1973; Howland, 1969). Simoes, et al. (1972) showed no difference in coppicing between axe or chain saw felling, and stem diameter had no effect upon regrowth. Shearing, however, may adversely influence the coppicing of stumps (Kerruish, 1978).

Stump mortality resulting from harvesting must be kept to a minimum since interplanting of existing stands is not feasible. Damage to the stump and roots by the felling device, and the other harvesting equipment is to some extent unavoidable. Thus, some increase in disease and subsequent stump mortality is inevitable. Kerruish (1978) recommends a smooth surface on the stump, a slight sloping to shed moisture, and little disturbance of the cambium. He notes that saw cuts are more suitable than axe cuts, and that recutting the original stump does not adversely affect coppicing. This is extremely important since shear-type mechanical harvesters may have to cut the stem at undesirable heights above the ground. The harvester can be followed by a chainsaw creating the proper conditions for optimum resprouting.

A stump height of 5-10 cm above the ground is recommended (Kerruish, 1978). Low growing coppice stems are less vulnerable to wind damage. Slash should be piled or removed at the time of harvesting so the stumps are free of logging debris. If the detrital fuel accumulation is high, a controlled burn when the soil moisture is high may prove highly beneficial to coppice growth. 
Carter (1974) recommends three coppice rotations following the initial harvest. An FAO (1955) study indicates coppice yields of pulpwood to be 120,90 , and 80 percent of the first rotations' yield. Myburgh (1967) found in South Africa that yields declined with every succesive cut; but, this parameter probably is highly variable. Little yield data are available from successive rotations. The number of possible coppice rotations is equally uncertain; but, for a species like $E$. camaldulensis, three coppice harvests appears to be a conservative estimate. Many more high yield coppice rotations are possible with the proper harvest techniques to protect the roots and stump, proper cutting of the stump, and the use of tissue culture plantlets selected for high coppice yields. Simoes, et al. (1972) showed that the most vigorous trees produced the most vigorous coppice, and that stump survival was independent of tree vigor.

In Florida, timing of the harvest could have an influence on stump survival and subsequent coppice success. Research underway in Glades County on the seasonality of coppicing by the U.S. Forest Service has shown a definite and strong decline in regeneration during the summer months. (G. Meskimen, pers. comm.). There has been no identification of the causitive factors. Hopefully, this subject will be better understood before BESI undertakes its first harvests. If necessary, most cutting can be scheduled for those months that favor coppice regeneration. This would necessitate extensive stockpiling of stems in the forest, and could induce a seasonality factor for the work force involved in harvesting .

Optimum coppicing is sufficiently necessary and valuable to justify adjustments in the other aspects of the eucalypt energy forest's management that interface with regeneration. 


\subsubsection{Site Preparation for Optimizing Yields of Coppice}

Rotations. The yield from coppice rotations can be enhanced by a number of site preparation procedures following the harvest. Mechanized harvesting should be done when soil moisture is low to avoid soil damage by compaction (Hassan, 1977; King and Haines, 1979; Moehring and Rawls, 1970). Soil texture on most Florida eucalypt plantations will favor the use of mechanization with little damage. If rutting is severe, a light discing may be desirable before leaving the site. Harvesting crews must be closely supervised to avoid damage to the soil, roots, and stumps.

Logging slash will be minimal because of the in-the-woods chipping of branches and tops. We expect that a controlled burn of the accumulated litter and debris will be desirable. Ash from the gasifier will be returned to the forest after harvest and applied between rows. Rock phosphate, and other minerals, nutrients, and trace elements will be applied as indicated by a full-spectrum soil testing program to evaluate soil depletion, if any, following a rotation cycle. The wood ash contains all the essential elements for tree growth, except for those removed by gasification (Motley, et al., 1980). The ash will improve soil texture and raise the $\mathrm{pH}$ in the more acidic flatwoods soils. In the mining region, gypsum applications also may improve yields.

After the harvest, a woods crew should dress-out the mechanicallyharvested stumps to favor coppicing. Stumps of select trees in the stand, the top 2-5 percent, should be marked and mapped for future comparison with the quality of the coppice regeneration. 
Site preparation following a harvest will be minimal in comparison to the preparation before the initial planting.

The controlled burn may obviate the need of a post-harvest herbicide treatment. Coppice regneration will dominate the site quickly; and, the established root systems will not lose their dominance. Probably, herbicides will not be required.

The stumps should be watched carefully during the first year following harvest for a possible increase in pathogenactivity. A fungicidal treatment may be effective if stump mortality from a number of possible disease agents is observed. This is not a significant problem in Florida at this time.

Experience and experimentation with eucalypt plantations in Florida will provide the basis for a better informed approach to between rotations site preparation.

Once coppice cut yields drop to $60-70$ percent of the original harvest, the stumps can be removed by bulldozer and burned if the land is to be placed into another use. If eucalypts are to be replanted, the stumps can be killed with an appropriate herbicide and the new trees planted between the rows. If site preparation between rows to reduce competition by the interplanting technique allows competing vegetation to capture the site, full site preparation as done for the initial plantingwill be required. Such decisions are almost a decade away and a great deal more information will be available upon which to base management decisions. 


\subsection{Wood Markets for Florida Eucalyptus. At the present time,}

we visualize four probable markets open in 1990 to Eucalyptus from Florida plantations: (1) a methanol refinery; (2) pulp; (3) fuelwood; and, (4) chemical feedstock.

\subsubsection{Methanol Refinery. The BESI engineering working} document on the methanol refinery gasification loop establishes the suitability of Eucalyptus wood for gasification and methanol synthesis. Similiar unpublished tests have been run on Brazilian Eucalyptus by a BESI consultant and support the same conclusion. Indeed, a Eucalyptus wood to methanol plant is said to be under construction at this time in Brazil. There is little of a specific nature in the literature on the gasification of eucalypts for methanol synthesis (Filho and 2agatto, 1980); but, wood is widely regarded as a suitable biomass feedstock for gasification (Johnson, 1980; Kohan and Barkhordar, 1979; OTA, 1980; SERI, 1979; Wan et al., 1980).

In the event a methanol refinery is constructed in the study area, it will require 70,000 to 100,000 acres of feedstock harvested on a 7 year rotation. Because of the competing markets for the eucalypt wood, the methanol producer should own or control at least $50 \%$ of the total feedstock required for full operations.

The availability of wood will be a determining factor when a methanol plant might begin production. At least 20,000 acres of plantation should be in the 6 th year, with another 15,000 acres in the 5 th year, before the plant could open. This assures a three year supply at start-up. It is unlikely that enough feedstock to sustain a methanol plant would be available for harvest before 1990, even if planting moves forward as rapidly as practical in 1983. 


\section{9 .2 Pulp. The suitability of eucalypts as a pulpwood}

has been well documented (FAO, 1975; Franklin, 1977; Franklin and Meskimen, 1975; Uhr, et al., 1972). The species tested vary considerably in their fiber characteristics, but $E$. camaldulensis fibers have good characteristics which permit their use in a number of different processes (FAO, 1975). Much of the Eucalyptus chips exported by Hawaii and Australia are used for pulpwood in Japan and Korea (Yang, et al., 1977) (Anon., pers. comm.). Most of the eucalypts in Brazil originally were planted for a pulpwood use, including the Jari plantations now being harvested and milled. The eucalypts in Glades County, Florida likewise were planted for the pulpwood market. Florida could become a major exporter of Eucalyptus pulpwood with sufficient plantations and effective marketing. World pulpwood stocks are inadequate and prices are likely to increase substantially for the rest of this century.

\subsubsection{Fuelwood. Fuel markets for Eucalyptus biomass} include residential stoves and fireplaces, industrial boilers, and power plants. All three markets have a high potential for development and expansion over the next decade before substantial acreages of the new Florida plantations are ready for harvest. BESI trials with $E$. camaldulensis cut in the sumer of 1981 as a residential fireplace fuel during the 1981-82 winter met with a high degree of consumer approval. We are looking toward larger trials next winter. Many Florida industries would like to achieve energy independence and fuel their own boilers, as well as cogenerate electricity. Several phosphate companies that are large consumers of electricity are studying the feasibility of building and operating power plants. Most of them have enough land to grow their own wood fuel. Existing coal-fired power plants can be expected to burn Eucalyptus fuelwood when it beomces available to lower air emissions in 
response to the acid rain problem. BESI is confident that the Central and South Florida fuelwood market of 1990 will compete to capture all of the supplies available from nearby eucalypt plantations.

\subsubsection{Chemical Feedstocks. Two recent editorials in}

Science predict a major increase in the use of biomass and wood as chemical feedstocks (Abelson, 1981; Abelson, 1982). Conceivably the chemical potential of wood might exceed in value its use as an energy source. The processing of cellulose holds great promise in manufacturing food and pharmaceuticals, as well as a host of other synthetic materials that now originate from coal and petroleum. Large stocks of wood feedstocks must be grown in close proximity to the processing industrial complex. Once the wood becomes available in sufficient quantitiy, some such new industry could displace the methanol refinery as the ultimate consumer of the eucalypt forests. 


\subsection{Economic Feasibility. Objectives of our wood-to-methanol.}

silvicultural research include an economic assessment of :

(1) the feasibility of Eucalyptus energy plantations as an alternative land use in the study region;

(2) the costs of establishing, managing, and harvesting these biomass plantations;

(3) the market potential and the probable price at harvest of Eucalyptus wood in the Florida and world markets;

(4) revenue potential; and

(5) break-even returns and profitability.

These assessments are made and discussed in the economics working docurnent.

There is great interest in the economics of intensively managed forest resources. Interest in woody-fuel systems springs from their potentially attractive economic returns compared to standard forest practices (Rose and Kallstrom, 1976), as well as direct competicion in the market place with fossil fuels. Research is just beginning in this area, and our review turned up no articles examining specifically the economics of intensively planted Eucalyptus. Even so, the extant literatura doco provide guidance as to methodology and computer programming. It is interesting to note that much of this literature is in the vein of standard micro-economic theory, but recognition of this relation is lacking.

The literature does establish the viability of intensively managed firest resources. As early as 1966, McAlpine, et al. (1966) reported on yields of intensively planted sycamores. McAlpine and Brown (1967) related their success in expanding yields by allowing for coppicing 
in short-term rotations. Cottonwoods received attention from McKnight (1970) and Heilman, et al. (1972) as an intensively planted species, and DeBell (1972) focused on alders. Poplar intensive cultures have been researched in the Lake States (Rose, et al., 1981). In the ensuing research more species were investigated and the research of economic methodology became more vigorous. Major reviews of the intensive culture literature were completed by Smith and DeBell (1973) and by Steinbeck (1973). It has become obvious from these studies that while copious amounts of biomass can be produced, this does not necessarily insure economic feasibility.

Economic factors received greater attention when Dutrow (1971) and Olawoye (1972) reexamined the sycamore. This emphiasis on economics received a major boost with the work of Rose (1975; 1977). Rose developed a generalized economic framework for analyzing intensive cropping practices, and he developed a computer simulation model. This represented a breakthrough of sorts by allowing analysts to conduct vigorous economic examinations of intensive plantings under conditions of imperfect information. This computerized analysis serves as the basis for the computer modeling to be conducted in this study.

The economic computer-model building technique developed by Rose (1975) was refined by Rose and Kallstrom (1976) and applied to other hardwood crops by Rose and DeBell (1978). Filho and Zagatto (1980) address the economics of a methanol from wood project in Brazil. The emphasis on economic analysis is vital since it is technially possible to produce copious amounts of biomass in short rotation silvicultural farms, but it may not be economically feasible (Howlette and Gamach, 1977). 
Intensive cultivation practices can be expensive. The additional costs must be realized in greater biomass yield. There are diminishing returns as more energy is injected into the system. Some researchers propose that the energy efficiency ratio is not nearly as important as the net returns, i.e. the available energy which is the difference between. energy input and energy output (Zavitkovski, 1979). The goal of intensive silviculture in wood energy systems should be to maximize output at a competitive price, yielding a reasonable profit. Such feasibility can be determined only through careful analys is which considers the best uses of the land and capital involved. 


\subsection{PLANTATION HISTORY}

Many of the observations, comments, and conclusions in this document are derived from the intensive study of two eucalypt plantations on reclaimed, phosphate strip-mining sites in Polk County, Florida (Figure 3-1). One planting is on overburden and one is on sand tailings. Site preparation at both plantations consisted of discing with a heavy disc pulled by a Caterpillar D-4 crawler tractor and bedded using a Rome heavy duty bedding and rolling harrow. Beds, 6-12 inches $(15-30 \mathrm{~cm})$ in height, were constructed on 12 foot $(3.7 \mathrm{~m})$ centers. Application of 0.5 ton acre $(1.12$ tonne/ha) of ground rock phosphate was made prior to discing. According to Lee Draper (pers. comm.), Container Corporation of America (CCA) research forester, $E$. camaldulensis seed for these plantings was provided by the U.S. Forest Service, Lehigh Acres Laboratory, to the Florida Division of Forestry's Herron Nursery. The seed originated from the Glades County seed orchard maintained by the U.S. Forest Service which was initiated with seed from a Spanish source of unknown provenance (E.C. Franklin, pers. comm.).

3.1 Overburden Planting. The overburden plantation is approximately a 10 acre ( 4 ha) planting off Walker Road in Section 28, Township 32 South, Range 24 East (Figure 3-1). The land has long been owned and managed by Agrico Chemical Company and its predecessors. Original land acquisition was for the purpose of phosphate mining. There is no recorded evidence of land improvement prior to mining. The pre-mining plant community was native rango dominatod by wiregrass, broomsedge grass, palmetto, gallberry, slash and occasionally longleaf pines, and various other plants typical of scrub flatwoods.

3.1.1 Mining. The property was mined from 1969 to 1971 . Mining depth ranged from 20-40 feet (6-12 m), and 5,000-8,000 tons/acre $(11,000-18,000$ tonne/ha) of phosphate ore was recovered through Agrirs's Payne Crccle washer, which lies about 1.5 miles $(2.5 \mathrm{~km}$ ) to the west. Mining was done with a Bucyrcus-Erie 1260B dragline, assembled on-site in 1964 near the washer.

\subsubsection{Reclamation. Reclamation of the area began in 1972 and} was completed in 1974. The reclamation was a land and lakes type, where overburden was relocated to lower areas by use of bulldozers and/or pans. Moderately 
FIGURE 3-1

Polk County Location Map

Agrico and Grace Plantations

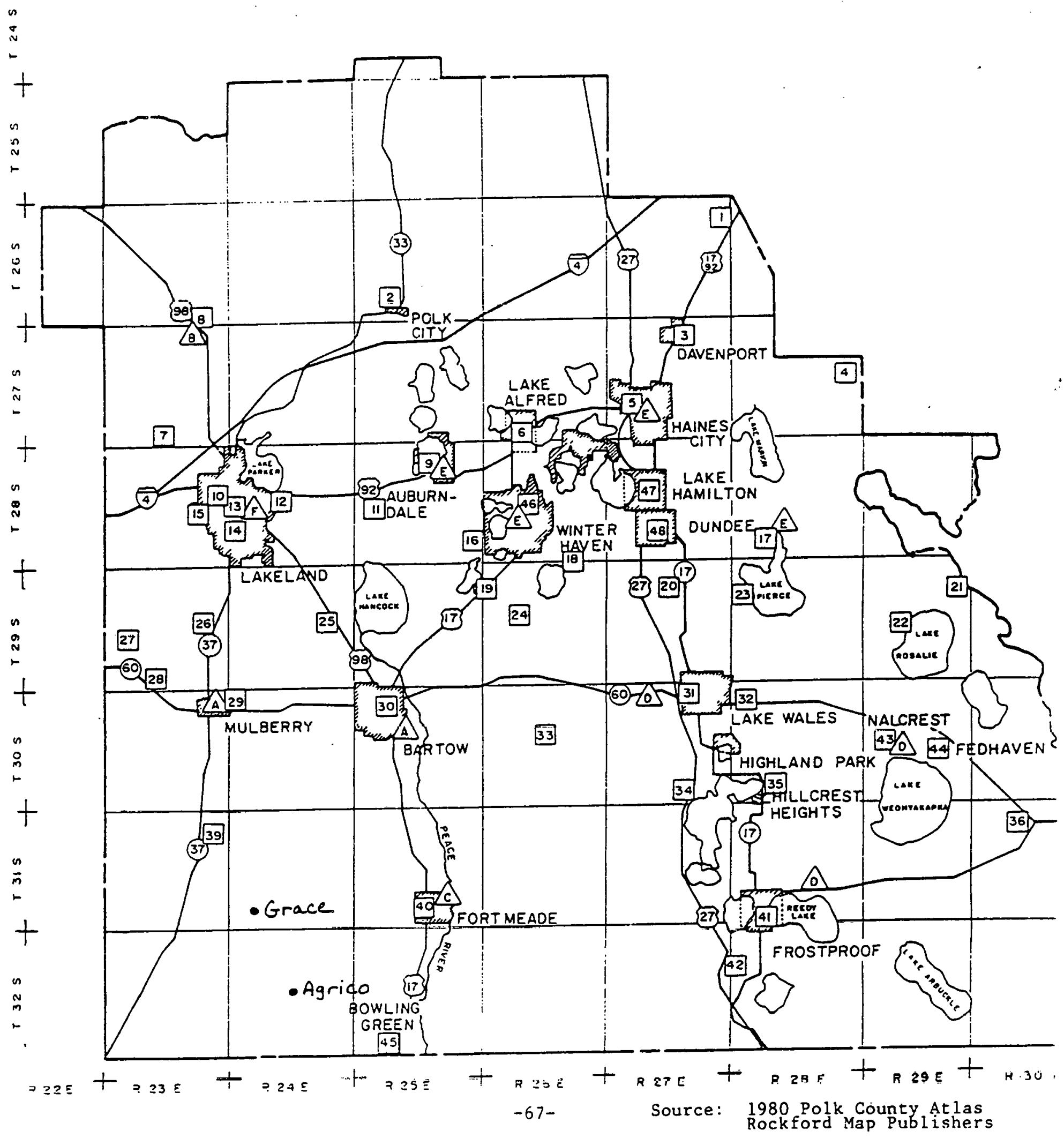


sized, interconnected water bodies were retained for cattle watering, wildife and fish habitat, and esthetic value. Improved bahia grass (Argentine) and winter rye (Gator) was planted in the southeastern portions of the area, as well as along the periphery of water bodies for erosion and sediment control.

\subsubsection{Planting. Eucalyptus camaldulensis and $E$. tereticornis} were planted in July 1974 by CCA. Approximately 8 acres ( 3 ha) of $E$. camaldulensis were planted in the plot's southern portion and 2 acres ( 1 ha) of $E$. tereticonnis on the north. Trees were planted 6 feet $(2 \mathrm{~m}$ ) apart within the rows, giving an original planting density of 605 seedlings per acre (1495/ha). Mean sea level elevations range from approximately 120-140 feet, $(36.6-42.7 \mathrm{~m})$ with Little Payne Creek in the northeast corner of Section 28 at approximately 110 feet (33.5 Other than the initial bedding, discing, and rock phosphate application of 0.5 tons per acre ( $1.12+/$ ha), no other silvicultural practices have been needed. Beds generally run east/west in order to intercept and otherwise impede rainfall runoff flowing down-gradient into the created water bodies. In some cases, old mine pipe was installed as "culverts" where large volumes of water were anticipated. Ground elevations generally fall from west to east and from south to north.

The planting procedure followed standard eucalypt forest establishment practices, using state-of-the-art recommendations from the U.S. Forest Service Laboratory at Lehigh Acres and the Florida Division of Forestry. As might be expected, residual phosphate levels, even seven years after planting, exceeded normally measured limits for $\mathrm{P}_{2} \mathrm{O}_{5}$ as provided by the University of Florida soil testing service. Presently, the trees show no obvious signs of phosphate degrade due to high phosphate levels. Preliminary soil testing and the determination of definitive soil nutrient needs is essential prinr tn planting large acreages. There should be no application of rock phosphate fertilizer to reclaimed mine soils unless a phosphate deficiency has been demonstrated by testing. Phosphate degrade may be correctible by additions of nitrogen and potassium, when necessary, to bring soils more nearly into the recommended nutritional balance for plant growth.

\subsubsection{Growth. At approximately $6-1 / 3$ years of age, the largest} Eucalyptus camaldulensis was 14.1 inches $(35.8 \mathrm{~cm}$ ) in diameter at breast height (dbh; taken at 4.5 feet or $137 \mathrm{~cm}$ above ground), and the tallest was 97 feet 
$(29.6 \mathrm{~m})$. Overall survival was 74 percent (450 stems/acre; 1,334 stems/ha). Less than 30 percent of the original planting had a dbh of 5.0 inches $(12.7 \mathrm{~cm})$ or more. Total per acre volume at $6-1 / 3$ years was estimated at 1,527 cubic feet $\left(106.85 \mathrm{~m}^{3} / \mathrm{ha}\right)$. Mensurational data from remeasurements by BESI foresters indicated growth increases of up to 20 percent from November 1980 to July 1981, demonstrating an absence of winter dormancy. This recent growth increase during a period when growth was expected to decrease, supports a hypothesis that the stand may be recovering from phosphate toxicity, and that early potential growth was never realized. Examples of $2 / 3$ year dbh increases covering all diameter classes are presented in Table 3-1 and 3-2.

3.2 Sand Tailings planting. The sand tailings plantation is an approximately 12-acre ( 5 ha) planting lying north of State Road 630 and southwest of Agrico's South Pierce Chemical Works, in Section 30, Township 31 South, Range 24 East (Figure 3-1, see page 67). This plantation was recently acquired by the Agricultural Chemicals Division of W. R. Grace and Co. for possible use as a waste disposal area.

3.2.1 Mining. The area was mined as part of the Hooker Prairie mining operation of the American Agricultural Chemical Company (AAC) and was a waste disposal site for AAC washer 非12. Thus, a greater mix of mined soils is aerated, with patches of overburden, sand tailings, clay, and debris intermingled. The property was mined during the 1940's and early 1950's. Information on mining depths and rock recovery is not available; however, the quality and quantity of the pebble fraction of the matrix was high, based on the relatively early mining date. Thus the levels of $\mathrm{P}_{2} \mathrm{O}_{5}$ in the plant root zone likewise will remain high over the long term.

\subsubsection{Reclamation. In 1969, a successor company to AAC, Agrico} Chemical Company, did some token reclamation in the area. Some low areas were filled and some peaks were eliminated. The area was planted with hairy indigo (a nitrogen-fixing legume and soil builder) and common Bermuda grass in 1970. Some indications of this initial planting are evidenced by the natural reseeding of indigo each year and the spread of common Bermuda grass where soil moisture is adequate. The indigo crop was never sufficient to warrant seed harvesting as intended. 
TABLE 3-1

\section{RECENT GROWTH INCREASE--OVERBURDEN}

\begin{tabular}{|c|c|c|c|c|c|c|}
\hline \multicolumn{2}{|c|}{ MEASUREMENT Nov. ' 80} & \multicolumn{2}{|c|}{ MEASUREMENT July ' 81} & \multicolumn{3}{|c|}{$\%$ INCREASE } \\
\hline $\mathrm{DBH}$ & HEIGHT & DBH & HEIGHT & $\mathrm{nBH}$ & HEIGHT & VOLUME \\
\hline $2.8^{\prime \prime}(7.1 \mathrm{~cm})$ & $27^{\prime}(8.2 \mathrm{~m})$ & $3.6^{\prime \prime}(9.1 \mathrm{~cm})$ & $30^{\prime}(9.1 \mathrm{~m})$ & 28.6 & 11.1 & 79.1 \\
\hline $3.1^{\prime \prime}(7.9 \mathrm{~cm})$ & $28^{\prime}(8.5 \mathrm{~m})$ & $3.8^{\prime \prime}(9.7 \mathrm{~cm})$ & $30^{\prime}(9.1 \mathrm{~m})$ & 22.6 & 7.1 & 58.5 \\
\hline $5.0^{\prime \prime}(12.6 \mathrm{~cm})$ & $44^{\prime}(13.4 \mathrm{~m})$ & $5.5^{\prime \prime}(14.0 \mathrm{~cm})$ & $52^{\prime}(15.8 \mathrm{~m})$ & 10.0 & 18.2 & 39.3 \\
\hline $8.0^{\prime \prime}(20.3 \mathrm{~cm})$ & $59^{\prime}(18.0 \mathrm{~m})$ & $9.1^{\prime \prime}(23.1 \mathrm{~cm})$ & $63^{\prime}(19.2 \mathrm{~m})$ & 13.7 & 6.8 & 37.0 \\
\hline $12.4^{\prime \prime}(31.5 \mathrm{~cm})$ & $66^{\prime}(20.1 \mathrm{~m})$ & $13.3^{\prime \prime}(33.8 \mathrm{~cm})$ & $72^{\prime}(21.9 m)$ & 7.3 & 9.1 & 24.2 \\
\hline
\end{tabular}


TABLE 3-2

RECENT GROWTH INCREASE--SAND TAILINGS

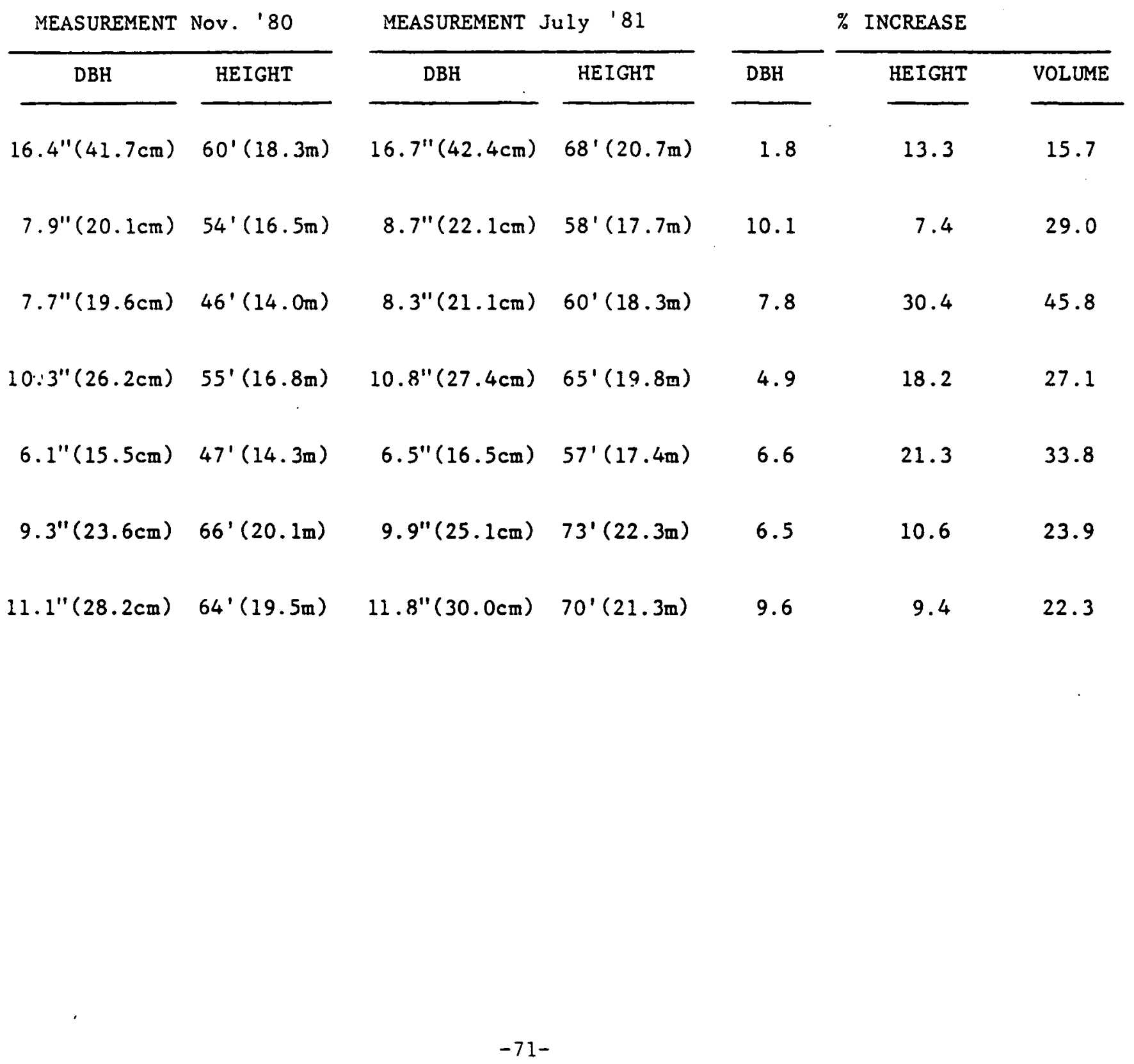


3.2.3 Planting. In the spring of 1974, CCA and Agrico decided to plant a 10-acre block of eucalypts ranging from nearly the highest point in elevation to the lowest. The depth of sand correspondingly ranges from approximately $50 \mathrm{ft}$. ( $15 \mathrm{~m})$ on the west to about $4 \mathrm{ft}$. (Im) on the east. Underlying the sand is a phosphatic clay residue of undetermined thickness. The site was planted with Eucalyptus camaldulensis, except for the westernmost six rows which are occupied by $E$. tereticornis. Mean sea level elevations range from 110-160 feet (33-49m). In 1975, an additional two acres were planted with $E$. tereticornis at the south edge of the original planting.

Both plantings were accomplished using the same recommended eucalypt forest establishment practices as at the Walker Road site. The planting density of 605 trees per acre $(1,495 / \mathrm{ha})$ also was repeated. Beds generally run north/ south to intercept and impede rapid rainfall runoff. This is a technique of erosion control not normally needed in the flat lands of peninsular Florida. The need for erosion control on tailings sand areas is less critical than erosion control measures on heavy soils. Because of rapid percolation and the depth of sand at maximum elevations, plants at the higher elevations are usually in a state of moisture deficit stress. Within one year after planting, both the leaves and stems of many plants became very red, indicating stress. A mineral deficiency was suspected initially; however, tests revealed the minerals and nutrients necessary for growth to be within acceptable ranges. Gradual changes from red to green beginning with heavier sumer rainfall and gradual reversal during droughty winter and spring months reinforced an interpretation of moisture deficit stress. The plants in the deeper sands at the higher elevations showed more evidence of moisture deficit stress, with poorer growth and survival. Neither the overburden nor the tailings plantation was subjected to ground cover and weed control practices; and, competition before canopy closure undoubtedly inhibited growth and decreased survival.

\subsubsection{Growth. Compiled data from the sand tailings planting} indicated that survival, height, diameter, overall volume and general plantation appearance improved at lower elevations within the site. The mean dbh of dominant and co-dominant stems in rows $1-20$ (lower elevation) was one inch $(2.54 \mathrm{~cm}$ ) greater than the mean for rows 21-40. Mean heights for the lower elevation was nearly 7 feet $(2.1 \mathrm{~m}$ ) more than stems at the higher elevations. Survival at lower elevations was 50 percent and 44 percent at higher elevations. The dominant stems downslope held a 34 percent volume advantage over stems occuring at the 
higher elevations. Soil tests to a 2 foot depth $(0.6 \mathrm{~m})$ did not reveal any major soil nutrient differences. The history of the area and an examination of discarded cores from recent exploration drillings (fine phosphate particles) indicated a higher moisture content at the lower elevations with a higher than normal occurrence of montmorillonite clays within reach of the plant's root system during early tree establishment.

Generally, each new phosphate recovery plant is more efficient than the last. A plant processing ore thirty years ago was relatively inefficient and failed to recover many of the phosphatic particles now recovered by improved methodology. Phosphate in the pebble deposits of Florida is recovered through a screening process. Pebbles are sized from a greater than 14 mesh to a less than 150 mesh. Fines, which fall in the less than 150 mesh are recovered from the sand fraction of the ore body through a float and reverse float process using various chemical agents and processes upon which technology continues to improve. Thus, the older mined soils have higher $\mathrm{P}_{2} \mathrm{O}_{5}$ levels than the recently mined soils. As at the overburden site, current phosphate levels exceed the normally measured limits of $\mathrm{P}_{2} \mathrm{O}_{5}$ as provided by the University of Florida soil testing service (Table 3-3). Again, the trees showed no morphological signs of phosphate degrade stress due to high $\mathrm{P}_{2} \mathrm{O}_{5}$ levels in the soil.

At approximately 6-1/3 years of age the largest $E$. camaldulensis. measured 16.4 inches $(41.7 \mathrm{~cm}) \mathrm{dbh}$ and the tallest $E$. camaldulensis was 73 feet $(22.3 \mathrm{~m})$. Overall survival was 59 percent (357 stems/acre; 882/ha); however, less than 30 percent of the original planting had a dbh of 5.0 inches $(12.7 \mathrm{~cm})$ or more. Total volume on a per acre basis at $6-1 / 3$ years was estimated at 1,410 cubic feet $\left(98.6 \mathrm{~m}^{3} / \mathrm{ha}\right)$. Data based on remeasurements by BESI foresters indicated growth increases of up to 20 percent or more during November 1980 to July 1981 . Again, this recent growth increase supports a theory that perhaps the stand is still in a state of recovery from early phosphate toxicity and that early growth potentiality was never realized, Other factors possibly contributing are reduced competition with understory plants and seasonally improved soil moisture conditions. Examples of $2 / 3$ year $d b h$ and height increases, which range through all diameter classes, are shown in Table 3-2 (see page 71). 
TABLE 3-3

SOII ANALYSIS AND RECOMENDAIIONS

SAND IAILINGS
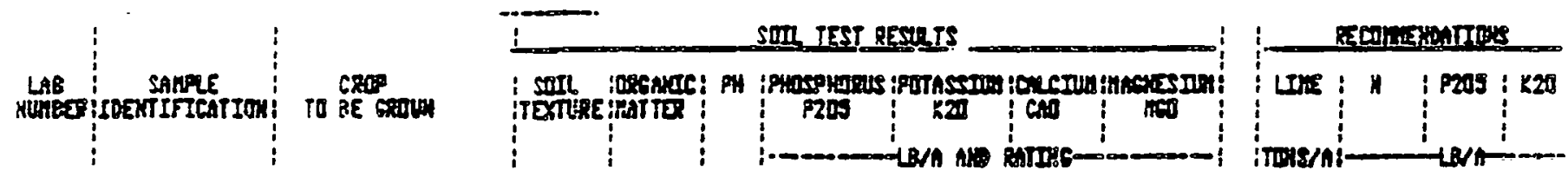

110521

Extriptotsers. ra.

sath Lo

3.5 736 VIL 19 428

$\rightarrow 4$

$0.7200 \quad 56$

1958 2

LA 3.9 9.9 4h 19 4h $=99$

80

0.0200

9 Is

210033

68

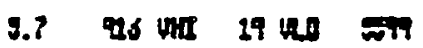

120

ค.) $\div$ st

120544

Li)

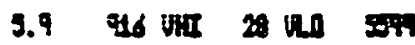

120

0.020 5o

21053 9

Everyptuses. Int) sto

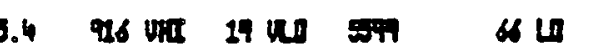

0.9260 50

110566

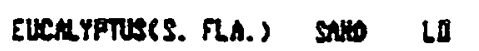

3.8026 ग31 19 un

is Lil

0.0200050

1993 ?

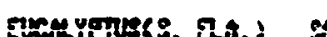

485

.

(2)

sent

14058

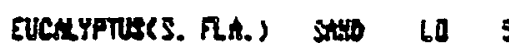

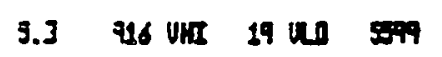

126

$0.0200 \quad 0$ 50 


\subsection{SITE PREPARATION}

4.1 Background. Experience in South Africa, South America, Israel, Hawaii, as well as Florida and the eucalyft plantation literature document that the optimum growth of eucalypts ultimately is determined by the quality of site preparation. Previous recommendations for the planting and establishment of eucalypt plantations in Central and South Florida have been: (1) disc and chop; (2) bed; (3) apply from 0.5 to 1.0 ton of ground rock phosphate per acre (1.12-2.24 tonne/ha); and (4) control native vegetation for at least one year after planting (Meskimen, 1971).

\subsubsection{South Florida. The native palmetto prairie and flatwoods} of South Florida, including Glades County, carry the only comercial plantings of eucalypts in the eastern United States. Site preparation, species selection, planting, and other silvicultural management recomendations from state and federal agencies generally have been directed towards this specific site. For example, there is no historic evidence of pine forests on the palmetto prairie. Therefore, there are no residual trees or stumps which would necessitate stump removal before the initial planting. Site preparation generally has not included the complete or long-term control of herbaceous and graminoid understory vegetation, although limiting competition in the first year is a recomended practice.

- Site preparation recomendations for South Florida have included chopping and/or double chopping as necessary to eliminate palmetto and other native ground cover competition. Typically, ground rock phosphate is applied at a rate of 0.5 to 1.0 ton per acre (1.12-2.24 tonne/ha). Single furrow planting beds, up to 2 feet $(61 \mathrm{~cm})$ in height and 4-6 (1.2-1.8 m) in width, are thrown-up on 12 foot $(3.7 \mathrm{~m})$ centers. Bedding is a standard treatment because inundation of all sites is probable during a normal rainy season. From Lake Okeechobee south to the tip of peninsularflorida, the slope of land is generally less than 2 inches per mile $(3 \mathrm{~cm} / \mathrm{km}$ ) and soils are waterlogged for extended periods. 
4.1.2 Central Florida--Native. Current site preparation practices for forest plantations in Central Florida vary according to two primary land types: (1) phosphate mined and reclaimed lands; and (2) native, unmined lands.

Recomended practices for the native, unmined lands include those treatments used in South Florida. As a minimum, land will be chopped and doubledisced (i.e., disced in two directions). Chopping should be done with a double drum chopper or its equivalent, and discing with an offset harrow having cutting blades at least 24 inches $(61 \mathrm{~cm})$ in diameter. As required, the chopped and disced land may be cross-disced with a citrus grove type disc having a 12-18 inch (30-46 cm) diameter cutting blade, if leveling or breaking of large clods is necessary. Bedding is necessary only if drainage is poor or if low elevations cause prolonged inundation. Pine stumps must be removed. Dependent upon the quantity, pine stumps can be a saleable item to stump wood distillers like Hercules, Inc. in Brunswick, Georgia or Reichhold Chemicals in Pensacola, Florida. If not saleable, stumps must be uprooted from the ground with a bulldozer, piled, and burned prior to chopping and discing. Chopping, discing, stumping, and bedding (as required) should be completed at least 20 days in advance of planting. Ideally, at least one l-inch $(2.54 \mathrm{~cm})$ rainfall should occur after preparation and prior to planting in order to settle the newly prepared soil substrate. In addition, a post-emergence type herbicide should be employed in order to keep the site clear of vegetative competition for at least 12 months. Herbicide recommendations will be discussed in the planting and maintenance sections.

\subsubsection{Central Florida--Reclaimed. Phosphate mined and reclaimed} lands can be among the most fertile soils in Florida. After mining and reclamation, these soils are characterized as sand tailings, overburden, sand-clay mix, or overburden cap over tailings, depending upon their respective roles in the mining process and the reclamation procedures. Since the native soils of peninsular Florida typically are Immokolee, St. Lucie, and other leached, infertile, and soil sandy types, the incorporation of kaolinite and montmorillonite 
clays at or near the ground surface enhances the water-holding capacity of reclaimed soils. Evidence indicates that mined soils show increasing $\mathrm{pH}$ values as clay content increases. Consolidated clay settling areas, which tend to be homogenous soil mixes (almost pure clay), have a $\mathrm{pH}$ of 7 or more.

\subsubsection{Site Quality. The site quality for plant growth} on various phosphate mined and reclaimed soils increases as the amount of incorporated sand tailings decreases. Our literature search has found no reference to site index tables for eucalypts like those available for the various pine species. Based on our observations, at $6-1 / 3$ years of age, the overburden plantings offer an almost straight line curve height advantage of 10 feet $(3 \mathrm{~m})$ for all diameter classes when compared to sand tailings. On both sites, annual growth exceeded 10 feet $(3 \mathrm{~m})$ in height and 1 inch $(2.54 \mathrm{~cm})$ dbh for the better trees.

Site quality for $E$. camaldulensis appears related to the availability of moisture, since empirical evidence suggests that it is influenced by the clay content of the upper soil strata. Site preparation for phosphate mined and created soils should include the incorporation of clays or a clay bearing overburden stratum as an integral part of the reclamation and 1 and reconstruction process.

While soil suitability is important in maximizing productivity, establishment of productive eucalypt plantations is possible on most natural and reclaimed soil types.

\subsubsection{Site Preparation. Preparation of reclaimed phos-} phate lands for eucalypt planting will require heavy discing, light discing and soil testing to determine the $\mathrm{pH}$ and available plant nutrients. In mined areas, stumping will not be a factor; but mining debris, such as rocks, pipes, cable, and other trash, often require manual removal. Raking may be needed between the initial and final discing in order to establish a smooth and level planting site. Bedding normally will not be a necessary part of site preparation on 
reclaimed land: Current state regulations dealing with reclamation of phosphate mined lands, except for wetlands reclamation, require adequate surface drainage and control of rainfall runoff.

Generally, $\mathrm{pH}$ should range between 6 and 7 in order that nutrients more readily may be taken up and utilized. If the $\mathrm{pH}$ is less than 5, lime or dolomite must be incorporated into the soil between discing operations. If soil testing reveals a need for dolomite or lime, applications probably would be in the range of 0.5 to 1.0 tons per acre ( 1.12 to 2.24 . tonne/ ha). For the Central Florida phosphate district, dolomite generally provides the best soil conditioning because of its magnesium content; however, the amount of magnesium varies by mining location. Magnesium requirements may dictate the material source. When installing eucalypt plantations, soil testing should determine shortages, if any, of certain other trace elements, such as boron, zinc, and iron. A one-time soil treatment is relatively inexpensive compared to losses of production associated with shortages of necessary minerals and trace elements. Normally, soil treatments have not been necessary in Florida except for the application of rock phosphate on native soils. Where excessive amounts of phosphate are available in the soil, there is the possibility of a phosphate degrade problem. This toxic response possibly may be overcome by applications of nitrogen and potash in order to achieve a more normal balance with the phosphate concentration. Much more research is needed before the phosphate degrade problem, if it exists at all, can be put to rest. Table 4-1 includes a selection of locally:available equipment which may be required for site preparation along with current list prices. 
4 wheel drive pickup for supervision and/or transportation to job site. Includes automatic trans., ps, pb, air, step bumper, dealer prep., destination charges.

$\begin{array}{ll}\text { Chevrolet } \mathrm{K}-10 & \$ 11,312+\operatorname{tax} \\ \text { Toyota ( } 5 \text { speed trans.) } & \$ 10,200+\operatorname{tax} \\ \text { Dodge ( } 318 \text { engine) } & \$ 9,400+\operatorname{tax}\end{array}$

Botrom Plow

$\$ 15003$ dise

Bulldozer w/rake and blade

$\begin{array}{lll}\text { Komotsu D-85-E-18 (26" shoes) } & \$ 193,900 & \text { Equiv. D-7 } \\ \text { Caterpillar D-7-G } & \$ 190,700 & \\ & & \\ \text { Komotsu D-155 (28" shoes) } & \$ 255,500 & \text { Equiv. D-8 } \\ \text { Caterpitlar D-8-K } & \$ 253,500 & \end{array}$

Wheel tractor 50-60 PTO HP

$\begin{array}{llll}\text { John Deere 2240 } & 50 \text { Hp PTO } & \$ 16,500 \\ \text { Ford 4110 } & 48 \text { HP PTO } & \$ 15,632 \\ \text { Ford 5610 } & 62 \text { HP PTO } & \$ 20,000 \\ \text { Massey Ferguson 255 } & 60 \text { HP PTO } & \$ 13,692 \\ \text { Deutz (air cooled) } & 60 \text { HP PTO } & \$ 13 ;, 426\end{array}$

Heavy ducy harrow TRH (Rome)

16 discs $30^{\prime \prime}$. dia $\$ 16,215$

20 discs $30^{\prime \prime}$ dia $\$ 18,120$

Bedding Harrow TRBR (Rome)

6 discs $30^{\prime \prime}$ dia $\$ 14,420$

Chopper (Single drum - Fleco) (Double drum - Marden)

$10^{\prime}$ wide-Single $\$ 25,315 \quad 12^{\prime}$ wide-Single $\$ 30,020$

$7^{\prime}$ double drum $\$ 26,325 \quad 8^{\prime}$ double drum $\$ 34,625$

$10^{\prime}$ double drum $\$ 38,425$ 


\subsection{PLANTING}

Planting commences after proper site preparation, and when soil moisture conditions and freeze hazards have been considered. Success is measured by a survival rate greater than 80 percent. Climatic conditions are the most likely threat to high survival, if the plant lines are selected for drought resistance and frost hardiness; and, if the laboratory and greenhouse production is of a high quality. The procedures in each instance are those we intend to use in the establishment of BESI plantations.

5.1 Climate. Trees of the genus Eucalyptus primarily are native to Australia, with many species renowned for their rapid growth characteristics. The natural distribution of eucalypts covers a wide range of climatic conditions; however, most do not do well where temperatures rapidly drop below freezing. Consequently, eucalypts have been planted extensively and exclusively in the warmer regions of the world for timber, fiber and energy production. In the continental United States, fast-growing eucalypts are grown comercially in locations like Southern California and South and Central Florida where killing frosts are infrequent and of short duration. This good fortune puts Florida in a unique position to capitalize upon one of the most productive woody biomass crops.

\subsubsection{Freeze Probabilities Relative to Eucalypts Cultivation.}

Central and South Florida's subtropical climate makes it the most suitable region with large acreages of land available for the cultivation of Eucalyptus within the continental United States. Over $50 \%$ of the reporting weather stations in Australia record minimum temperatures comparable to peninsular Florida (Mariani, et al., 1978). This permits the introduction of a variety of species/provenances that have promising biomass potential, many of which are thus far untested in Florida. 
Freezing temperatures within the eucalypt region are primarily restricted to the months of December, January, and February. In the study area of West-central Florida, the mean date of the first freeze ranges from December 20 to January 20 and the mean date of the last freeze ranges between January 10 to February 10 (Table 5-1). Individual trees are producing woody biomass throughout the year unless defoliated by a freeze or fire.

Most of the more productive eucalypt biomass candidates also tend to be the least cold tolerant. The most important criterion determining the extent of freeze damage is the age and size of the trees exposed to a given freeze event. Young saplings are particularly susceptible to cold damage, whereas older trees are more resistant. In addition, prevailing temperatures during the period preceding a freeze event are critical in determining damage to cold sensitive plants of all ages.

Even when planting a frost resistant Eucalyptus species recommended for this area, like $E$. camaldulensis, freezing temperatures could be sufficiently cold to devastate a newly installed plantation before the trees have grown enough to optimize resistance. The damaged trees can be expected to respond with coppice growth. The period between mid-November and early March have freeze probabilities ranging from 10 to 100 percent in Polk County. Planting during this time span is a calculated risk. However, for large scale commercial biomass operations, extension of the planting period is essential to efficientoperation of plantlet supply systems. Reasonable estimates of loss potential can be made using the University of Florida's Institute of Food and Agricultural Science freeze probability charts (Bradley, 1975) and then applied to a risk-benefit analysis. Freeze probabilities from the Lake Alfred station (Polk County) are presented in Figure 5-1. Planting might reasonably be extended to include October in the fall and February in the spring if moisture was not a critical factor. With more experience and research, greater frost resistance can be developed through genetic improvement and vegetative propagation. 
TABLE 5-1

Frobable Freeze Dates

PROBABLE DATE OF

FIRST FREEZE

$$
\begin{aligned}
& \mathrm{T} \leq 32{ }^{\circ} \mathrm{F} \\
& \mathrm{T} \leq 28^{\circ} \mathrm{F} \\
& \mathrm{T} \leq 24^{\circ} \mathrm{F} \\
& \mathrm{T} \leq 20^{\circ} \mathrm{F} \\
& \mathrm{T} \leq 16^{\circ} \mathrm{F}
\end{aligned}
$$

\begin{tabular}{|c|c|c|c|c|}
\hline .10 & .25 & .50 & .75 & .90 \\
\hline Nov 24 & Dec 10 & Dec 27 & Jan 14 & Feb 1 \\
\hline Dec 10 & Dec 26 & $\operatorname{Jan} 20$ & * & $*$ \\
\hline Jan 13 & $*$ & $\star$ & * & * \\
\hline$\star *$ & $\star *$ & $* *$ & $* *$ & $* *$ \\
\hline$\star \star$ & $* *$ & $\star \star$ & $\star *$ & $* *$ \\
\hline
\end{tabular}

PROBABLE DATE OF

\begin{tabular}{|c|c|}
\hline .90 & 75 \\
\hline $\operatorname{Dec}_{\forall} 28$ & $\underset{*}{\mathrm{Jan}} 16$ \\
\hline * & $\star$ \\
\hline$\star \star \star$ & $* *$ \\
\hline$* \star$ & $* *$ \\
\hline
\end{tabular}

LAST FREEZE

$T \leq 32^{\circ} \mathrm{F}$
$T \leq 28^{\circ} \mathrm{F}$
$T \leq 2{ }^{\circ} \mathrm{F}$
$T \leq 20^{\circ} \mathrm{F}$
$\mathrm{T} \leq 16^{\circ} \mathrm{F}$

LAKE ALFRED
.25

.10

Feb 3

Jan 12

$\star$

$\star *$
Feb 21

Feb 1

*

$\star * *$
Mar 8

Feb 16

Jan 14

$* *$

* Less than indicated probability

**Less than 5 occurrences 
FIGURE 5-1

Freeze Probabilities

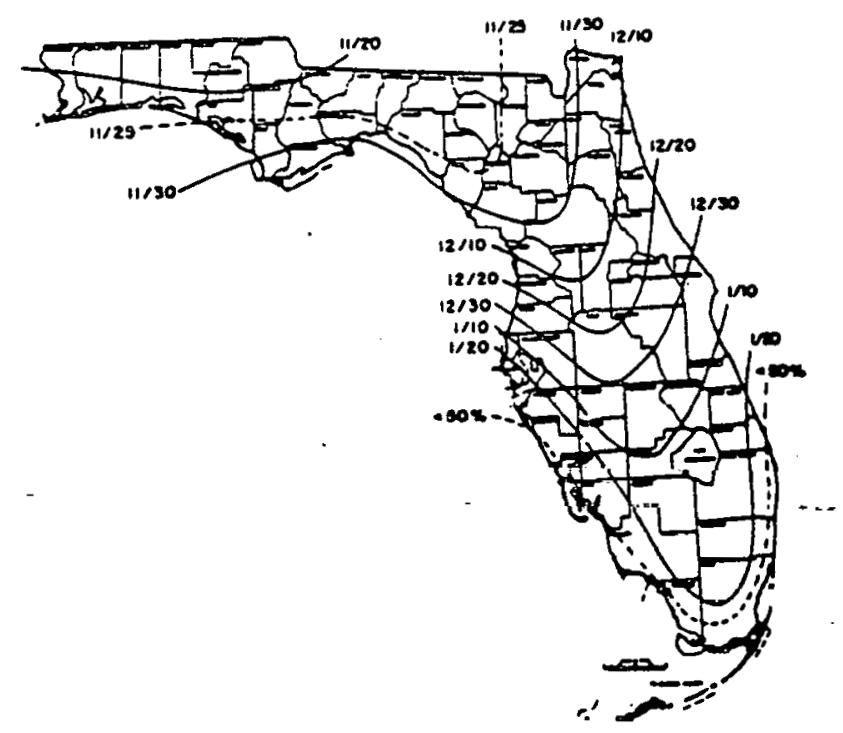

MEAN UATE (50\% YROBABILITY) OF FIRST $\left(32^{\circ} \mathrm{F}\right)$ FREEZE OCCURRENCE.

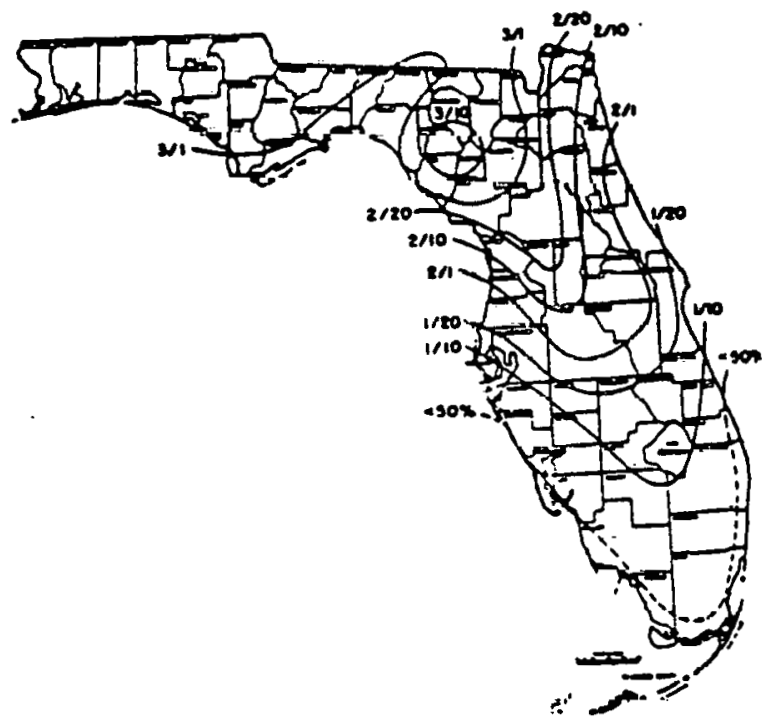

MEAN DATE (50) PROEABILITY) OF LAST $(32 \%$ F) FREEZE OCCURIRENCE. 
In general, the prevailing temperature conditions in the region are suitable for high yield biomass production. Each species and particular site condition ideally should be matched to provide the most efficient achievement of this goal. Based on temperature conditions alone, Central Florida plantations should not perform significantly differently from existing Florida eucalypt plantations.

\subsubsection{Moisture as a Limiting Factor to Eucalypt Survival} and Growth. Eucalypt distribution can be classified according to rainfall in Australia: i.e., species from uniform rainfall zones, species from summer drought/winter rainfall zones and species from winter drought/ sumer rainfall zones. Most forestlands in Australia correspond with winter drought/sumer rainfall, or uniform rainfall zones, and are similar to Florida in this respect.

Water is perhaps the most important factor determining the success of vegetative establishment in Florida. Due to a predictable lack of adequate precipitation in the months of March, April, and May; eucalypt planting in Southwest Florida occurs mainly in the months of June and July, sometimes extending to August and September. This is necessary since newlyplanted Eucalyptus trees of many species require some rainfall within the initial weeks of planting in order to survive.

Over most of the study area, there is a greater than 50 percent chance of at least 0.50 inches of rain per week during the mid May-September period (Butson and Prine, 1968). During the rest of the year there is a 20 to 40 percent chance of no rain during any given week (Table 5-2). Under these conditions, watering of trees could be initiated during no-rainfall planting periods as is done in some Brazilian plantations; however, the economics of a watering operation on large acreages does not appear feasible for Florida. Some sites may have an irrigation capability from prior cropping systems. For most sites, the most reasonable alternative to either irrigation or not planting would be to plant known drought-tolerant plantlets during the dry months. 
TABLE 5-2

Percent chance of selected rainfall amounts per week at Lake Alfred and Moore Haven

Based on weekly rainfall during the 41 year period 1925-1965.

\begin{tabular}{|c|c|c|c|c|c|c|c|c|c|c|c|}
\hline \multicolumn{2}{|c|}{$\begin{array}{c}\text { - } \\
\text { Week } \\
\text { Beginning }\end{array}$} & & ne & $\frac{\text { cent }}{.50}$ & 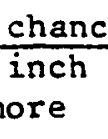 & 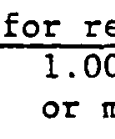 & $\frac{\text { ceivin }}{\text { inch }}$ & $\begin{array}{c}\frac{\operatorname{rainf}}{2.0} \\
\text { or }\end{array}$ & 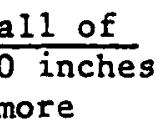 & $\begin{array}{r}\text { Greates } \\
\text { weekly } \\
\text { (inc }\end{array}$ & Greatest amour \\
\hline Jan & 3 & 31 & 31 & 34 & 23 & 15 & 12 & 5 & * & 3.60 & 2.47 \\
\hline & 10 & 35 & 32 & 33 & 22 & 15 & 10 & 7 & * & 3.55 & 1.94 \\
\hline & 17 & 33 & 26 & 33 & 22 & 16 & 11 & 7 & * & 2.37 & 4.10 \\
\hline & 24 & 31 & 24 & 34 & 22 & 18 & 13 & 7 & 5 & 3.20 & 2.60 \\
\hline & 31 & 23 & 22 & 39 & 28 & 23 & 75 & 8 & 7 & 2.93 & 3.71 \\
\hline Feb & 7 & 34 & 23 & 41 & 29 & 21. & 16 & 9 & 5 & 3.08 & 3.01 \\
\hline & 14 & 24 & 25 & 41 & 31 & 25 & 17 & 11 & * & 3.60 & 2.20 \\
\hline${ }^{\circ}$ & 21 & 20 & 27 & 41 & 31 & 22 & 19 & 11 & * & 2.84 & 3.09 \\
\hline Mar & 1 & 29 & 27 & 43 & 33 & 27 & 20 & 13 & $*$ & 3.24 & 4.06 \\
\hline & 8 & 28 & 22 & 43 & 37 & 28 & 20 & 11 & 5 & 2.99 & 1.81 \\
\hline & 15 & 26 & 20 & 43 & 37 & 32 & 20 & 11 & 5 & 8.70 & 4.20 \\
\hline & 22 & 25 & 20 & 44 & 38 & 34 & 22 & 12 & 8 & 3.74 & 3.34 \\
\hline & 29 & 27 & 24 & 46 & 39 & 37 & 24 & 11 & 11 & 5.60 & 3.98 \\
\hline Apr & 5 & 30 & 28 & 46 & 38 & 38 & 23 & 13 & 10 & 3.35 & 4.57 \\
\hline & 12 & 34 & 28 & 42 & 37 & 31 & 26 & 11 & 11 & 5.08 & 5.56 \\
\hline & 19 & 33 & 27 & 41 & 38 & 24 & 26 & 10 & 10 & 4.75 & 3.17 \\
\hline & 26 & 31 & 24 & 37 & 41 & 20 & 31 & 7 & 10 & 4.96 & 2.33 \\
\hline May & 3 & 30 & 24 & 39 & 43 & 21 & 28 & 7 & 10 & 6.30 & 4.25 \\
\hline & 10 & 30 & 24 & 41 & 46 & 28 & 33 & 12 & 15 & 7.31 & 2.85 \\
\hline & 17 & 23 & 21 & 52 & 51 & 37 & 34 & 20 & 24 & 3.99 & 3.83 \\
\hline & 24 & 17 & 19 & 61 & 56 & 46 & 46 & 26 & 30 & 5.62 & 8.90 \\
\hline & 31 & 10 & 14 & 69 & 63 & 47 & 46 & 29 & 30 & 6.27 & 7.08 \\
\hline June & 7 & 9 & 10 & 72 & 69 & 48 & 54 & 28 & 33 & 5.82 & 6.24 \\
\hline & 14 & 7 & 6 & 76 & 78 & 57 & 59 & 35 & 35 & 13.08 & 7.69 \\
\hline & 21 & 7 & 5 & 74 & 77 & 60 & 62 & 37 & 36 & 16.19 & 5.25 \\
\hline & 28 & 8 & * & 76 & 80 & 65 & 64 & 36 & 31 & 4.97 & 9.56 \\
\hline July & 5 & 7 & * & 77 & 80 & 63 & 63 & 32 & 30 & 3.83 & 5.20 \\
\hline & 12 & 6 & * & 83 & 84 & 66 & 67 & 34 & 35 & 6.12 & 3.81 \\
\hline & 19 & $\star$ & * & 85 & 80 & 61 & 60 & 35 & 37 & 6.26 & 4.89 \\
\hline & 26 & $*$ & * & 85 & 78 & 56 & 59 & 33 & 36 & 5.26 & 5.28 \\
\hline Aug & 2 & $*$ & * & 82 & 75 & 55 & 55 & 29 & 31 & 3.57 & 4.84 \\
\hline & 9 & $\star$ & * & 82 & 77 & 62 & 59 & 28 & 28 & 10.58 & 6.54 \\
\hline & 16 & $\star$ & * & 81 & 76 & 64 & 56 & 29 & 30 & 4.73 & 5.34 \\
\hline & 23 & $*$ & * & 80 & 81 & 63 & 59 & 31 & 32 & 5.98 & 5.18 \\
\hline & 30 & $\neq$ & * & 78 & 79 & 59 & 59 & 30 & 36 & 10.42 & 5.89 \\
\hline Sept & 6 & $\star$ & * & 77 & 77 & 58 & 58 & 30 & 33 & 13.15 & 7.46 \\
\hline & 13 & 10 & * & 71 & 77 & 50 & 54 & 24 & 31 & 5.94 & 7.09 \\
\hline & 20 & 11 & 5 & 63 & 69 & 46 & 49 & 23 & 26 & 4.77 & 10.26 \\
\hline & 27 & 13 & 8 & 48 & 60 & 35 & 42 & 16 & 22 & 4.54 & 9.86 \\
\hline
\end{tabular}

* Percent chance less than 5

(continued on next pago)

Moore Haven

Lake Alfred 
TABLE 5-2 (continued)

\begin{tabular}{|c|c|c|c|c|c|c|c|c|c|c|c|}
\hline \multicolumn{2}{|c|}{$\begin{array}{c}\text { Week } \\
\text { Beginning }\end{array}$} & & & $\begin{array}{l}\frac{\text { cent }}{.50} \\
\text { or }\end{array}$ & $\begin{array}{l}\text { inch } \\
\text { nore }\end{array}$ & $\begin{array}{c}\text { for } r \\
\begin{array}{c}1.0 \\
\text { or }\end{array}\end{array}$ & $\frac{\text { ceivin }}{\text { inch }}$ & $\begin{array}{l}\text { rainf } \\
2.0 \\
\text { or }\end{array}$ & $\frac{11 \text { of }}{\text { inches }}$ & \multicolumn{2}{|c|}{$\begin{array}{l}\text { Greatest amount } \\
\text { weekly rainfall } \\
\text { (inches) }\end{array}$} \\
\hline \multirow[t]{4}{*}{ Oct } & 4 & 22 & 13 & 42 & 52 & 33 & 37 & 15 & 21 & 3.64 & 6.40 \\
\hline & 11 & 33 & 23 & 34 & 44 & 26 & 34 & 12 & 27 & 5.09 & 4.06 \\
\hline & 18 & 39 & 30 & 31 & 34 & 20 & 26 & 9 & 15 & 9.25 & 7.25 \\
\hline & 25 & 44 & 33 & 23 & 26 & 12 & 19 & $*$ & 10 & 1.46 & 1.75 \\
\hline \multirow[t]{5}{*}{ Nov } & 1 & 43 & 32 & 23 & 18 & 10 & 12 & $*$ & 5 & 2.05 & 3.55 \\
\hline & 8 & 47 & 37 & 20 & 17 & 13 & 12 & $*$ & 5 & 3.90 & 3.07 \\
\hline & 15 & 45 & 42 & 22 & 17 & 12 & 10 & * & * & 5.40 & 1.52 \\
\hline & 22 & 45 & 43 & 22 & 14 & 12 & 6 & 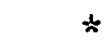 & $\therefore$ & 4.13 & 2.487 \\
\hline & 29 & 43 & 41 & 23 & 15 & 11 & $*$ & * & * & 2.17 & 0.87 \\
\hline \multirow[t]{4}{*}{ Dec } & 6 & 40 & 37 & 27 & 16 & 13 & * & $*$ & * & 2.24 & 2.61 \\
\hline & 13 & 36 & 35 & 28 & 20 & 19 & 8 & 6 & * & 1.74 & 1.97 \\
\hline & 20 & 31 & 29 & 33 & 23 & 20 & 13 & 6 & * & 2.82 & 5.56 \\
\hline & 27 & 29 & 33 & 34 & 24 & 21 & 14 & 7 & * & 2.91 & 2.30 \\
\hline
\end{tabular}

* Percent chance less than 5

Moore Haven

Lake Alfred 
Normal drought conditions in the fall or spring should not be detrimental to established plantations. Damage has been observed from two consecutive extreme drought years in existing Glades County, Florida eucalypt plantations. Reduced growth is a probable result of prolonged drought. Drought tolerant eucalypt species may not experience a significant growth reduction on droughty sites. Again, moisture has its most crucial influence during the early establishment months. Provided eucalypt species are matched to appropriate site and climatic conditions, well-established plantations should weather the seasons quite well. Only the most extreme weather events appear to significantly impact on the existing stands, particularly the linking of a severe freeze with stress from prolonged drought.

\subsubsection{Comparisons of Climatic Conditions in Southwest and} West-central Florida. The pioneering efforts in eucalypt cultivation in Central and South Florida by the U.S. Forest Service (Lehigh Acres) and their cooperators suggest that Eucalyptus grandis, $E$. robusta, $E$. camaldulensis, $E$. tereticornis and $E$. viminalis are the most promising candidates for near-term commercialization. In addition, species such as $E$. macarthurii and $E$. nova-anglica are candidates for more northern locations.. Some 20,000 acres $(8,000$ hectares $)$ in Southwest Florida's Glades County have been planted to $E$. grandis, E. robusta, and their hybrids.

It is presently unclear to what extent comerical plantations of $E$. grandis and $E$. robusta should be restricted to South Florida because of their cold-sensitivity. Both species are found growing in Central Florida. The extent to which they may be commercially grown north of Glades County remaines undetermined. In fact, these fast-growing species may outperform more cold tolerant species despite annual freezes. The apparently severc damage frum the January 1982 freeze awaits evaluation. 
Cooperative eucalypt plantings by the U.S. Forest Service and

St. Regis Paper Company in Sumter County, approximately 50 miles north of the study area, have exhibited superior "freeze-coppice" growth for these two species after seven years, despite a number of severe cold spells. It has been suggested that "freeze-coppice" rotations are a viable alternative to exclusive use of cold-tolerant species (E. C. Franklin, pers. comm.).

Actual comparisons of Southwest Florida and West-central Florida climates reveal slight differences in minimum temperature regimeo (Figure 5-2). Annual average minimum temperatures within the study region range from 25 to $28^{\circ} \mathrm{F}\left(-4\right.$ to $\left.-2^{\circ} \mathrm{C}\right)$. Average minimum temperature for Webster, near the Sumter County eucalypt plantings (ST-76) was $23^{\circ} \mathrm{F}\left(-5^{\circ} \mathrm{C}\right)$; significantly lower than temperatures found in the northern portions of the study area. Conversely, the Labelle area in Southwest Florida appears only slightly warmer than most of the study region.

A closer look at freeze intensity and duration suggests both differences and similarities between che Central and South Flnrida regions (Table 5-3). The largest difference lies in the occurence of temperatureo below $32^{\circ} \mathrm{F}\left(0^{\circ} \mathrm{C}\right)$. Freezing temperatures are longer and more frequent in Bartow (representative of West-central Florida), with virtually no possibility of a "frost-free" year. However, there is only a 20 percent chance of a "frost-free" year in Labelle (representative of Southwest Florida). Thus, freezing temperatures, however infrequent, must be expected in Florida eucalypt plantations. Prolonged temperatures below $25^{\circ} \mathrm{F}\left(-4^{\circ} \mathrm{C}\right)$ are the most threatening to Florida eucalypts.

Reviewing the occurence of temperature regimes of $\leq 28^{\circ} \mathrm{F}\left(-2^{\circ} \mathrm{C}\right)$ and $\leq 24{ }^{\circ} \mathrm{F}$ $\left(-4^{\circ} \mathrm{C}\right)$ reveals decreasing differences between the two regions. Temperatures $\leq 24^{\circ} \mathrm{F}$ are almost equally infrequent in Labelle as in Baztow. Both regions have less than a 20 percent chance in any winter of experiencing such low 


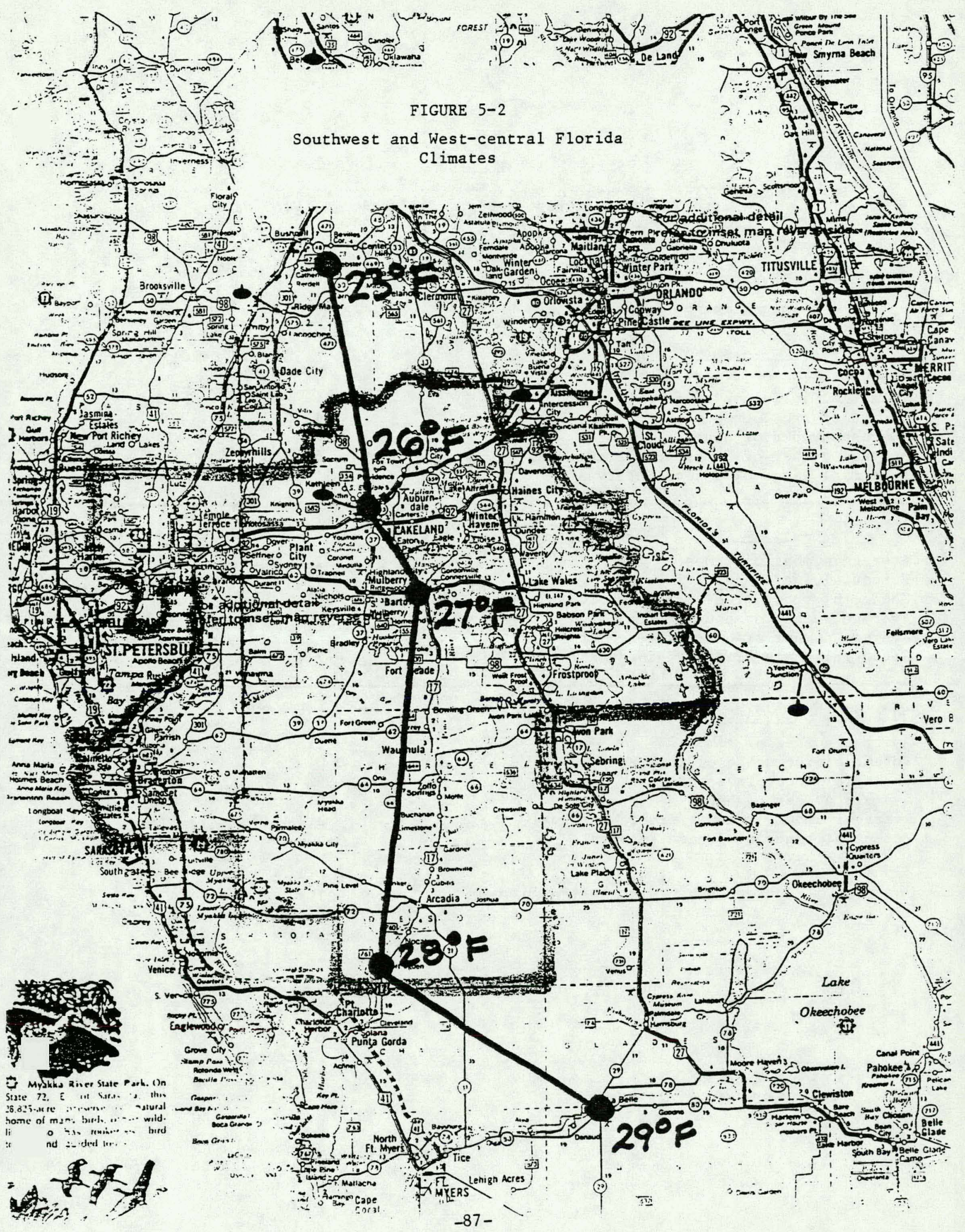


TABLE 5-3

Historic Temperatures at Bartow and LaBelle, Florida

(1937-67)

ANNUAL FREEZE DATA

$32^{\circ} \mathrm{F}$

Average number of times

Potential incidence of freezes

Chanre of froot frep yest

Average number of livuls

Average number of hours/freeze interval

Potential range of freeze interval
BARTOW

LABELIE

$\begin{array}{cc}7 & 3 \\ 1-14 & n-9 \\ <1 \%(0) & 20 \% \\ 34.4 & 11.9 \\ 5.1 & 3.7 \\ 2-11.5 & 0-5.8\end{array}$

$$
28^{\circ} \mathrm{F}
$$

Average number of times

Potential incidence of freezes

Chance of frost free year

Average number of hours

Average number of hours/freeze interval

Potential range of freeze interval

$\begin{array}{cc}2 & <1(.83) \\ 0-7 & 0-3 \\ 27 \% & 43 \% \\ 9.0 & 2.3 \\ 4.0 & 3.0 \\ 0-7.7 & 0-7.5\end{array}$

$$
24^{\circ} \mathrm{F}
$$

Average number of times

Potential incidence of freezes

Chance of frost free year

Average number of hours

Average number of hours/freeze interval

Potential range of freeze interval

AVERAGE ANNUAL MINIMUM TEMPERATURE

$\begin{array}{cc}<1(.93) & <1(.1) \\ 0-3 & 0-2 \\ 83 \% & 94 \% \\ 0.9 & 0.3 \\ 3.1 & 2.8 \\ 0-5.0 & 0-3.0 \\ & \\ 27^{\circ} \mathrm{F} & 29^{\circ} \mathrm{F}\end{array}$


temperatures. Extremely low temperature events tend to impact on a greater portion of the state with more uniformity; whereas, generally colder temperatures are more frequent in North and Central Florida due to the effect of stationary and dissipating cold fronts.

Consequently, a devastating freeze in a eucalypt plantation in West-central Florida is not a necessarily more likely event than in Southwest Florida. Indeed, the January 1982 freeze was more severe in LaBelle than in Lakeland. Experimental field plantings are necessary to determine the potential of $E$. grandis, $E$. robusta and their hybrids, as well as more cold-sensitive species, to perform well through West-central Florida's winter. Even with more data, climatic factors can be expected to influence major events in the management of the eucalypt plantation.

5.1.4 Species Selection and Improvement Program. Figure 5-3 compares areas of similar climate (homoclines) to peninsular florida using the methodology developed by Papadkis (1970). These areas roughly correspond with the world maps of climatology which utilize climatic diagrams for stations around the world (Landsberg, et al., 1965). Unfortunately, these attempts at comparing sites for plant introduction suitability are 1 imited, since soils are not considered. For example, in humid regions sandy soils are dry because they retain only small amounts of rainwater whereas moisturebinding clay soils remain wet; however, the reverse is true in arid climates where the infrequent downpours must be absorbed quickly for soil storage (Waller, 1973). Consequently, climate alone is not a predictor of plant performance in an exotic landscape. Ultimately, field performance is the only positive verification.

Since field trials screening species of eucalypts for those best adapted to South Florida have been limited, with virtually none in Central Florida, species/provenance trials are an essential research component of a large-scale, woody biomass program. A number of heretofor untried 
FIGURE 5-3

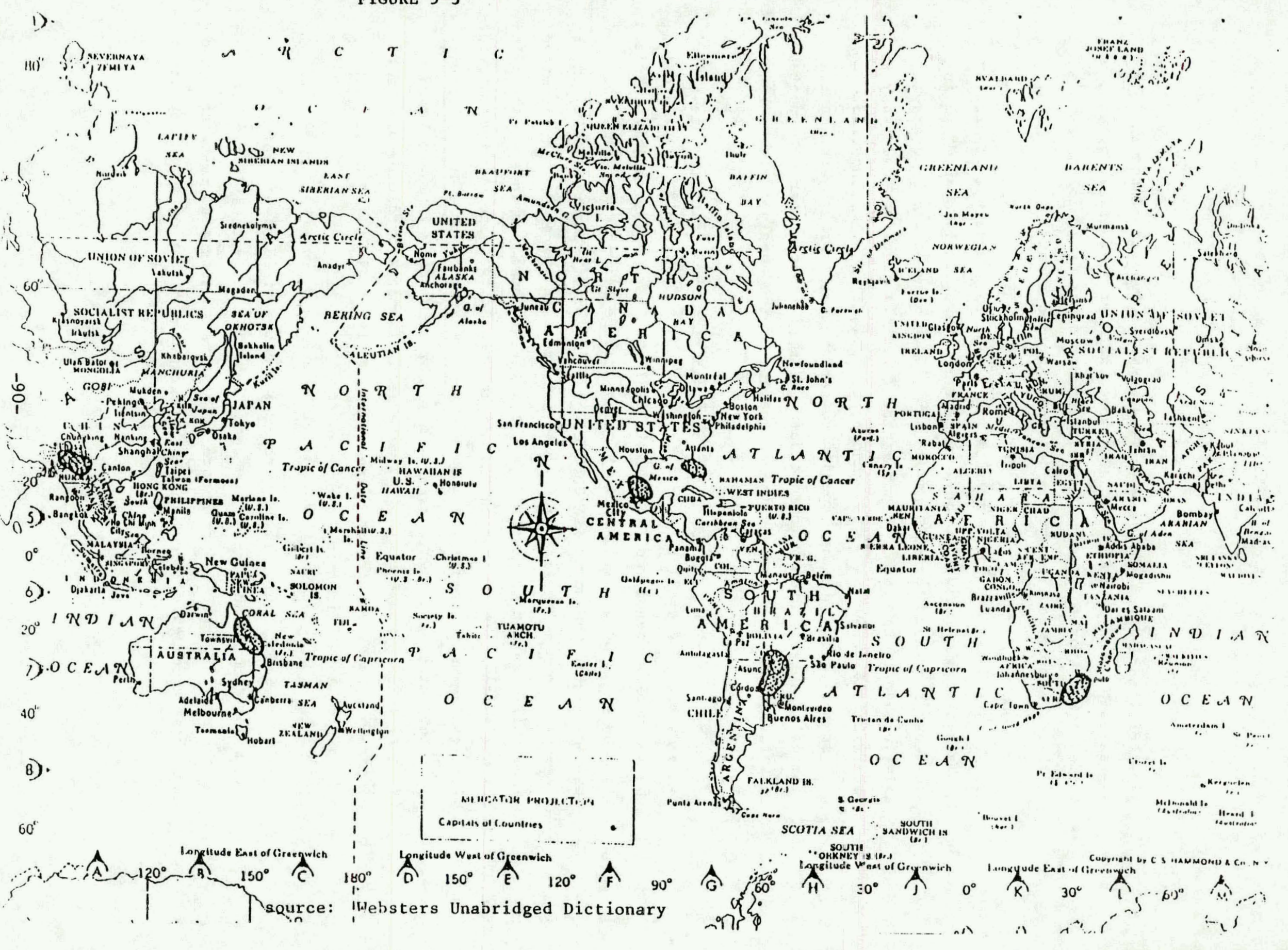


species or provenances may prove useful or better adapted to specific site conditions. However, immediate commercialization efforts must concentrate on improvement of eucalypts growing in the area that show superior characteristics.

Tissue culture propgation allows for replication of phenotypic characteristics which often are representative of superior genotypes. Improvement of planting stosk can be accelerated. immensely by selecting high-performance "clones" for outplanting. Due to the relative success of $E$. camaldulensis on mined land in Central Florida, Biomass Energy Systems, Inc. is undertaking a program of producing clonal stock from "select" trees. In vitro propagation from seed of premier $E$. grandis and $E$. robusta mother trees also are underway for testing in the field. 


\subsection{Spacing and Density. Plantlets will be machine planted}

using a spacing of 5 feet between plants in the row and 10 feet between rows $(1.5 \mathrm{~m} \times 3 \mathrm{~m})$. This will provide a planting density of 871 plants per acre $(2,152 /$ ha $)$ and allow each plant a potential growing space of 50 square feet $\left(465 \mathrm{dm}^{2}\right)$. As a supplemental spacing regime, rows may be alternately spaced at 8 feet $(2.4 \mathrm{~m})$ and 12 feet $(3.7 \mathrm{~m})$, with a continued 5 foot $(1.5 \mathrm{~m})$ spacing within the row (Fig. 5-4). This would allow stem spacing experimentation while maintaining the recommended planting density. Spacing variation between rows should be considered in those areas where bedding is required. Potential damage to lateral roots through compaction will be reduced by allowing an extra two feet $(0.6 \mathrm{~m})$ for the harvesting machinery.

The selection of a 10 foot ( $3 \mathrm{~m}$ ) distance between rows is based on presently available harvesting equipment, although future equipment development and/or modification may allow woody biomass plantings at a greater density. Consideration also must be accorded the cost of producing planting stock, as well as survival and yields. Some close-spaced plantings have experienced early mortality. In plantings of 1 foot by 1 foot $(0.3 \mathrm{x}$ $0.3 \mathrm{~m}$ ), mortality was approximately 50 percent (Hillis and Brown, 1978). At a plant cost of $\$ 0.08$ each, and a production of 42.8 tonne/ha at age 3 , wood value would have to be $\$ 207.68 /$ tonne just to recover the cost of plants. In the same study, a planting of 2 feet by 2 feet $(0.6 \times 0.6 \mathrm{~m})$ experienced an early mortality of 36 percent. Production at this spacing at 3 years was 32.9 tonne/ha. Using the same cost factor ( $\$ 0.08$ per plant), wood values to recover plant cost must be $\$ 67.55 /$ tonne. At a spacing of 2 feet by 8 feet $(0.6 \times 2.4 \mathrm{~m})$. survival was 93 percent, and the wood value to recover the cost of plants would be reduced to $\$ 15.96 /$ tonne.

Sachs, et al. (1980) experimented with a density of 17,790 $E$. grandis seedings per hectare in southern California; with twice a year harvests. Yields were 22 oven-dried metric tons per hectare per year. While there was an overall low initial mortality of 8 percent, 
Figure 5-4

Example of Plantation Design

Spacing Average $5^{\prime} \times 10^{\prime}(1.5 \mathrm{~m} \times 3.0 \mathrm{~m})$
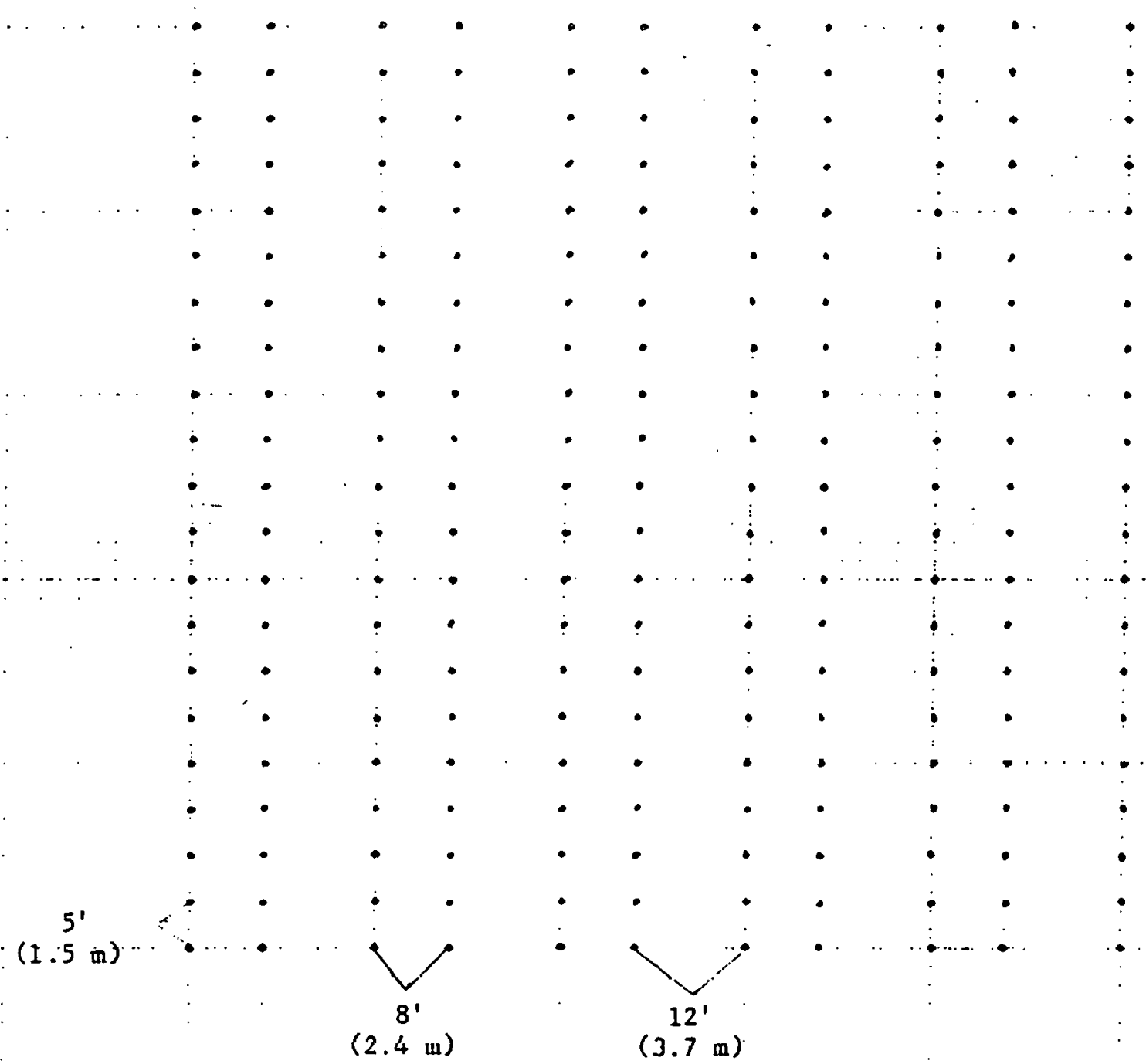
some plots had a high mortality. While this approach produces a high yield of biomass, we have rejected it for our BESI plantations for a number of reasons, the cost of establishment versus yield being foremost.

Studies of close spacing of popular (Populus spp.) hybrids and jack pine (Pinus barksiana) reveal high mortality at six years for $9 \times 9$ inches $(1.9 \times 1.9 \mathrm{~cm})$ and $12 \times 12$ inches $(2.54 \times 2.54 \mathrm{~cm})$ spacings. The authors caution against extrapolating to large scale forest plantings (Dawson, et al., 1980).

Various spacing studies indicate that maximum annual incremental growth occurs at 5-6 years in spacings where individual stems have 65195 square feet of growing space (595-1, $821 \mathrm{dm}^{2}$ ) (Walters, 1980). Height growth at age 5 appears to be about equal at all spacings. At age 5 , the widest spacing shows a $25 \%$ advantage over the closest spacing when contrasting dbh values. This advantage increased to about 31 percent at age 15. Walters (1980) indicates that the widest spacing used, $14 \times 14$ feet $(4.3 \times 4.3 \mathrm{~m})$, probably is best economically for sawtimber yields. As spacing was reduced, cubic foot $\left(\mathrm{m}^{3}\right)$ production increased. Walters (1980) speculates that a spacing narrower than $8 \times 8$ feet might result in a greater volume per unit area.

Our choice of the spacing of 5 feet $(1.5 \mathrm{~m})$ within the row and an average of 10 feet $(3 \mathrm{~m})$ between rows, considers a projected maximizing of volumetric increases over a predicted rotation age, coupled with presently available off-the-shelf equipment and requirements to consumate an economically sound program of woody biomass production and use.

5.3 Methodology. Automated, or at least semi-automated equipment for planting containerized stock, is in various stages of development. No off-the-shelf automated tree planter is presently available because of the wide variety of container sizes being employed by plant growers. However, both Don Demerest of Speedling (pers. Comm.) and Ed Bradley of 
Southern Machinery (pers. comm.) have indicated that they can furnish automated equipment guaranteed to perform to specified planting requirements. Nursery production in Todd Planter Trays (Speedling) offers the convenience of planting directly from the nursery tray, a system we intend to employ. This eliminates the necessity of pulling and repacking plantlets prior to delivery to the planting site. Without the shock of pulling and repackaging, the need for refrigeration is eliminated. Moderate air circulation and adequate moisture controls are necessary requirements. One expert anticipates no problem in pulling plantlets directly from the Todd Trays on the planting machine (Demerest, pers. comm.). Cost savings in packaging, handling, transportation, and storage are anticipated.

Plants can be held in planting trays for two weeks or longer, if absolutely necessary, after removal from the nursery. Daily inspection and watering is required to maintain the planting stock in a plantable condition. Other extraordinary labor and/or time consuming procedures, such as heeling in, should be avoided. The greatest cost savings is achieved when the plants move directly from the greenhouse to the planting machine. 
Proposed plantations will be designed to take advantage of reasonably long, uninterrupted rows. Clonal planting blocks of 160 acres (65 ha) are recommended with rows one-half mile (approx. $805 \mathrm{~m}$ ) in length. Each row requires 528 plantlets, or less than 9 compartmentalized Todd Planting Trays ( $8^{\prime \prime} \times 16^{\prime \prime}$ ) for a round trip of the planting machine. Utilization of 160-acre (quarter section) planting blocks are a harvesting asset because of compatibility with the internal road network. Compartmentalized planting blocks alsn simplify the management of iudividual clonal blocks.

Planting will be done at the speed which most nearly optimizes the hand/eye coordination of the planter with the speed of the tractor. The speed of the tractor also is limited by the quality of site preparation, the tracking efficiency of the planter, and the topography of the site.

Under ideal planting conditions and with optimum site preparations, we would not expect a two-man crew planting by hand to exceed a daily production of 1500 plants. Labor at $\$ 5 /$ hour for a 10 hnur/day resulto in a planting cost of about $\$ 0.07$ per plant, or nearly $\$ 64$ per acre. Using the same labor cost and adding a tractor and mechanical tree planter, we can increase by at least 10-fold the number of plants planted. Assuming 
the same ideal planting conditions and optimum site preparation, Jonathon Futch of Futch Timber Company (pers. comm.), indicates that planting will, on a day in day out basis, exceed 25,000 plants per day. Assuming an expenditure of $\$ 15,000$ for five year life equipment and 50 gallons per day fuel use, the cost for machine planting will probably be less than one cent per plant.

\subsection{Seasonal Considerations. Poor success is frequently experi-} enced in forest-type plantings (primarily pine) performed in Central and South Florida during December through May. The degree of winter-planting success generally diminishes southward from Ocala. Winter rainfall in Florida is usually the result of cold fronts moving in a northwesterly to southeasterly direction across the United States. In many cases these fronts, which cause so much hardship for other locales in the nation, are pushed eastward or northeastward by air convection currents associated with the warm Gulf waters surrounding peninsular Florida. Central and South Florida usually escape the hard freeze, low temperatures associated with these cold fronts. This plus is somewhat offset by a deprivation of winter moisture. The spring months of March-May are even drier. If you're vacationing in Florida, warm, dry, and sunny is your winter preference: but, if you're a planter or grower of eucalypts then you "bet your trees and take your chances" by planting during Florida's predictably dry winter/spring seasons. One of the best ways to hedge your bet is to plant drought resistant, cold hardy lines of $E$. camaldulensis. Normal weather patterns for central Florida, and prior historical data, confirm the occurrence of high rainfall from June through October, and low accumulations from November through May. In order to take advantage of adequate moisture and warm temperatures necessary for good plant establishment, eucalypt planting primarily is recommended for June through October, although later plantings may take place in November and December. The resistance of the plants to cold and drought is essential for winter/ spring plantings. 
Eucalypts planted during the optimum sumer/fall planting period should reach heights exceeding normal frost inversion patterns well in advance of anticipated frosts in Central florida. Later plantings, while probably not attaining the heights necessary to escape frost damage, should have established adequate root systems and stored sufficient plant food reserves to resprout and otherwise recover when temperatures moderate. Ben Swendsen, Ranch Manager for Lykes Bros., Inc. (pers. comm.), confirms the rapid recovery of cold damaged young eucalypt plants when weather moderates. Damage to plants set out by Lykes Bros., Inc. during July through September 1980 varied from :slight to nearly complete defoliation during the 1980-81 winter months. Trees (1980 planting) completely defoliated in February 1981 showed little evidence of damage and were approaching heights of 20 feet $(6 \mathrm{~m})$ or more by the fall of 1981. These same trees were damaged severely a second time by a January 1982 freeze.

5.5 Air Quality. The combustion of fossil fuels releases many hazardous chemicals and particulates into the atmosphere. Air pollution levels are high enough in some urban areas and their airsheds to cause damage to vegetation. Vegetative damage induced by sulfur dioxide $\left(\mathrm{SO}_{2}\right)$ and fluorides such as hydrogen fluoride (HF) and silicon tetrafluoride $\left(\mathrm{SiF}_{4}\right)$, oxidants such as ozone $\left(\mathrm{O}_{3}\right)$, and others are well documented (Loomis and Padgett, 1973).

There is no documented literature on pollution damage to trees of the genus Eucalyptus; but, there is strong evidence that all plants can be damaged at some level by air pollutants. Potential problem areas might be immediately adjacent to heavily-trafficked highways or phosphate chemical plants which have, at times in the past, emitted levels of pollutants harmful to nearby vegetation. In actuality, air pollution damage is not anticipated. If air quality becomes a problem, genetic selection for pollution tolerant genotypes could be initiated. Man's efforts to maintain adequate levels of air quality generally will protect eucalypt trees as well. Large acreages of eucalypt forests should enhance the overall regional air quality. 


\subsection{Native Vegetation as an Indicator of Land Suitability for}

Eucalypts. Vegetation responds to variations in topography, soil, moisture, and climate by organizing as distinct plant communities best suited to particular edaphic conditions. Consequently, much about conditions at the planting site can be inferred from the local native plant community. Vegetative indices are particularly useful where detailed soil mapping has not been performed, as in Hardee and DeSoto Counties.

Scrub and sandhill vegetatinn occupy the xeric forest sites and indicate deep, droughty sands. Wetlands, both forested and non-forested, occupy the lowland areas. Hardwood hamocks can be found on a variety of xeric to hydric sites, although most now occur in lowland areas. The vast 
flatwoods and prairie lands extend across the imperfectly drained flatlands. This last vegetative category coincides with areas currently deemed ideal for widespread cultivation of eucalypts. In addition, xeric sites have potential for drought tolerant eucalypts.

The natural landscape of the five-county study area has been significantly altered as a result of agricultural and urban development. Within these general categories, a variety of specific uses and management practices determines the extent of vegetative cover. In turn, the density and vigor of existing vegetation is directly related to the potential vegetative competition for planted eucalypts-a critical consideration in eucalypt establishment (Meskimen, 1971).

The rangelands primarily consist of cut-over flatwoods and palmetto prairie. Eucalypts in Glades County are grown on these lands. Site preparation includes chopping, discing, and bedding. The prairie sites have no stumps. Intensive site preparation appears successful in reducing competition to newly planted eucalypts; but, it must be effective for at least the first year so the trees can capture the site. Although all shrubs are eliminated, vigorous herbaceous growth often rebounds in the first 6 months, doubling herbage yields withing one year (Moore and Swinde1, 1980). This situation provides ample opportunities for growth suppression of the young eucalypts due to competitive stress. The current success with eucalypts in South Florida may be attributed in part to the shallow-rooted nature of the competing native grasses.

Improved pasture and cropland provides a wide variation in herbaceous competition. Bermuda and bahia are common, deep-rooted pasture grasses. Roots commonly descend up to 6 feet $(2 \mathrm{~m}$ ) into the soil in search of food and water, presenting a severe stress potential for trees. Intensive site preparation alone would only rearrange the rhizomes which would 
resume vegetative growth quickly. Under such conditions, herbicide treatments are needed. One logical alternative would be to sell the sod prior to planting, although a herbicide treatment probably would still be necessary. Newly-abandoned cropland provides a fertile substrate for tree growth, provided herbaceous colonization is controlled. Older abandoned farmlands require intensive efforts to control ruderal plants.

Mined and newly-reclaimed land is the product of the most effective vegetative control known to man. Inversion of soil horizons and destruction of topsoil. Maintenance would be necessary but minimal due to the lack of seed or rhizomes in the soil. Older mined lands present more difficulty in regard to vegetation control and would require the elimination of competition similar to that required of older abandoned farmlands.

The study area is presently quite depauperate of forestlands. Forests, excluding wetlands, cover less than 5 percent of the total land area. Riverine and scrub forests dominate this acreage. Extensive stands of longleaf pine ( $P$ inus palustris), and to a lesser extent slash pine (Pinus elliottii), once covered the vast flatlands and sandhills of the region. Clearcutting and controlled burning have all but eliminated these forests in exchange for rangeland uses.

The droughty sandhills not planted to citrus have a variety of scrubby vegetative associations. Oak scrubs composed of Bluejack oak (Quercus incana), Chapman's oak (Quercus chapmannii), Scrub live oak (Quercus geminata) and Turkey oak (Quercus laevis) predominate. Most of the pines have been eliminated except for areas colonized by sand pine (Pinus clausa). Due to the limited economic utility of these lands in their natural state, citrus groves are rapidly replacing the native vegetation. An excellent opportunity exists for coppice management of naturally occuring oak thickets, and cultivation of sand pine. This type of biomass cropping would be low in commercial productivity but extremely valuable from a natural ecosystem conservation perspective. BESI intends to emplny methods of maintaining native forest communities within the eucalypt plantations on the sites least suited for eucalypts. 
The greatest existing natural woody biomass resource exists along the valleys of rivers, creeks, strands, as well as in isolated lowland pockets. These wetland and lowland forests are highly productive due to increased availability of nutrients and moisture. Most of the forests are second and third generation regrowth. These forests provide significant values to man for fish and wildife habitat, water quality enhancement, and recreation. Clearing is not recommended for native forests. However, it may be desirable to manage these riparian forests by selective cutting or strip clearcutting as a means of balancing environmental and economic values. As these forests mature, pressures to harvest the timber will increase. Currently, there is no effective restriction of logging activity on private lands.

More damaging in the long-term is the complete elimination of streamside forests along tributaries and in headwaters area, as well as free access of cattle to stream courses. These areas could sustain short-rotation cutting of selected species while maintaining their support functions to more critical downstream ecosystems, Other nonforested areas adjacent to stream forests:could be.converted to biomass plantations. Bald cypress (Taxodium distichum), red maple (Acer rubrum) and sweetgum (Liquidambar styraciflua) are ideal candidates for establishment in soils too waterlogged for eucalypts. BESI does not expect eucalypt plantations to displace native forests, particularly forested wetlands, because of the high cost of clearing; and, even more importantly, because most of the remaining native forest sites are not suitable for highly mechanized eucalypt plantations. 


\subsection{SPECIES SELECTION}

6.1 Eucalypt Suitability. The Mitre study (Howlett \& Gamache, 1977) indicated that eucalypts are potentially the best biomass source for Florida. Eucalyptus camaldulensis is one of the most widely planted species outside of Australia, and has consistently met with establishment and growth success in field trial locations. Individuals of this species have proven adaptable to soil types ranging from very wet to very dry, and very clayey to very sandy. In Central Florida, where temperatures occasionally fall below $20^{\circ} \mathrm{F}\left(-8^{\circ} \mathrm{C}\right)$, the less cold-tolerant species normally planted in South Florida (e.g., E. grandis and $E$. robusta) might have unsatisfactory production and survivorship. These plantings were severely damaged in the January 1982 freeze. Further investigation is warranted before either ruling out or recommending a Central Florida planting of the two species used in: South Florida.

The original source of Eucalyptus camaldulensis planted in Florida is presumed to be from seed grown in Spain (hence, a localized identification of "Spanish cam" has evolved over the years). Reinforcing other studies, and confirming the potential of $E$. camaldulensis as a biomass candidate, is our own study of two 10-acre ( $4 \mathrm{ha}$ ) plantings in Polk County, Florida.. These plantings confirm the cold resistance of this species, since the 1980-81 winter (December 1980-February 1981) was the coldest prolonged Florida winter in 150 years. Yet, tree by tree examination in Polk County showed little in the way of freeze damage.

Planting recomendations for Central Florida most notably have been limited to $E$ : camaldulensis, $E$. tereticornis, and $E$. viminalis. There is, to our knowledge, no plantation-type planting of $E$. viminalis in Florida. of the $E$. tereticornis plantings observed, damage due to cold (as evidenced by leaf burning or browning and leaf loss) affected more than 75 percent of observed stems as opposed to less than 25 percent damage to $E$. camaldulensis. 
Both $E$. camaldulensis and $E$. tereticornis at the ST-76 planting on St. Regis Paper Co. property in Sumter County, approximately 10 miles $(16 \mathrm{~km}$ ) west of Groveland, suffered heavy damage. However, the most successful undamaged trees appeared to be $E$. camaldulensis. The ST-76 site is 50-75 miles north of the proposed planting areas of Polk County and subject to much more severe winter weather.

6.2 Monocultural Containment. Not all Florida eucalypts are able to produce viable seed. This was an important consideration in selecting E. camaldutensis as a candidate.species. There has been considerabie environmental concern expressed over plantation ouczlypts oscaping into the wild and dominating natural systems. While $E$. camaldulensis has been known to flower nearly the year-round, Geary and Meskimen (in ms) state that both $E$. camaldulensis and $E$. tereticornis normally flower from midNovember to mid-January in Central and South Florida. Almost without exception, immature seed capsules of "Spanish cam" are aborted, said to be caused by a fungal pathogen. Ample evidence has been observed around the base of mature $E$. camaldulensis to confirm the occurrence of flowering and fertilization in the fort of aborted, immature capsules. Attempts to harvest seed largely have been unsuccessful.

The non-production of seed, while limiting in some respects, offers an ecological and environmental advantage over many exotic plants. There has been much written about encroachment of certain exotic (non-native) species which have been introduced into Florida, particularly in the southern portion of peninsular Florida which has subtropical growing conditions that encourage plant establishment. These concerns have been addressed in the impact assessment document. Furalypis have been widely planted throughout South Florida for over a hundred years without posing a significant invasion problem. 
6.3 Propagation. The non-seed producing characteristic of Florida's "Spanish cam" was known from the outset of this project, necessitating vegetative propagation to reproduce select trees of this species, in this instance through tissue culture. Eucalypts may be reproduced by grafting, but this is slow and costly, with uncertain results. Large-scale clonal plantation establishment has been accomplished in Brazil using rooted cuttings. The cost of labor in the U.S. frequently prohibits such labor intensive methodology, even though a high degree of success may be achieved elsewhere. Our limited experience with propagation of rooted cuttings indicated excessive costs per established plant when grown for any reason other than research. Based on small scale production to-date, high yield ecualypts produced by tissue culture and multiplied in large quantities cannot be cost competitive with seedlings unless the increased yield is factored into the comparison.

\subsubsection{Selection Criteria. As part of the examination of two} "Spanish cam" plantations in Polk County, all stems with a dbh greater than 9 inches $(22.8 \mathrm{~cm})$ were located and plotted within the stands for easy relocation. Diameter is the single greatest contributor to volume and has received the highest priority in our selection system (even-aged planted stand). As an example, see Table 6-1 showing tree volumes for diaeters ranging from 5 to 18 inches and heights of 50 to 90 feet. A one inch increase in diameter causes a volume increase greater than that created by a ten foot increase in height through most diameter classes and height increments.

Crooked and/or forked trees have been eliminated by our selection process because of increased handing and transportation costs. These greater costs result because of higher labor costs (additional time to reduce to single stem) and increased equipment costs because of poor stackability on wood hauling and handling equipment. Also, a high incidence.rof. forking in the stands of eucalypts we have examined results in a disproportionate incidence of wind damage with resulting volume reductions and losses in yield. 
TABLE 6-1

VOLUME (cubic feet) COMPARISON USING TWO VARIABLES

DBH

\begin{tabular}{lllll}
\hline 50 & 60 & 70 & 80 & 90 \\
\hline
\end{tabular}

$5^{\prime \prime}$

2.68

3.14

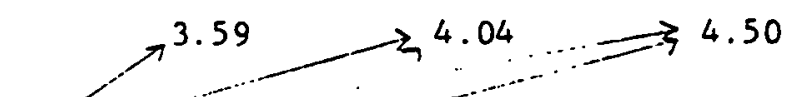

6"

3.86

$\leftrightarrow 5.17<$

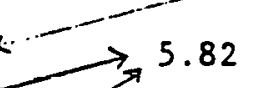

6.48

$7^{\prime \prime}$

3.26

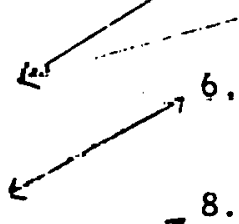

$8^{\prime \prime}$

6.86
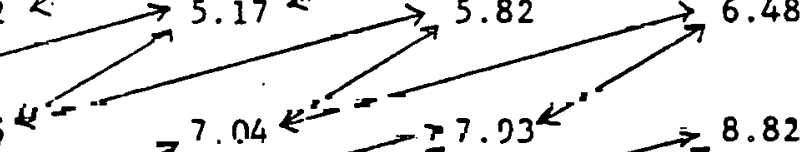

$9^{\prime \prime}$

0.69

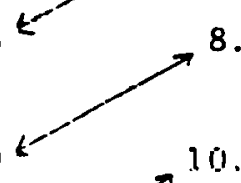

$8.03<9.19$

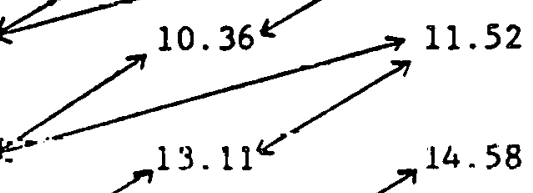

$10^{\prime \prime}$

10.73

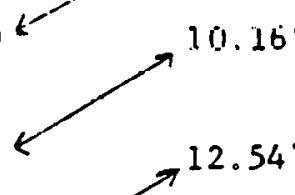

$16^{2} 11.63^{6}$

$\pi^{13.11^{K}}>^{14.58}$

$11^{\prime \prime}$

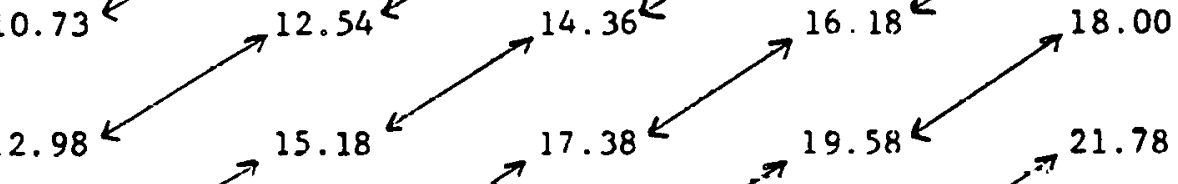

$12^{\prime \prime}$

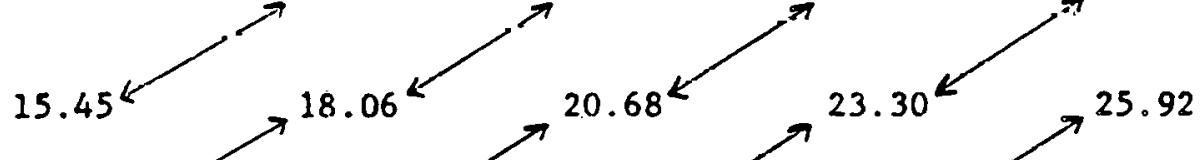

$13^{\prime \prime}$

$18.13^{K}$
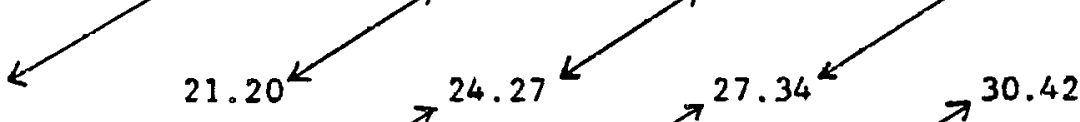

$14^{\prime \prime}$

21.02

$15^{\prime \prime}$

24.13

$28.22^{K}$

$24.59^{K}$

$28.15^{\leftarrow}$

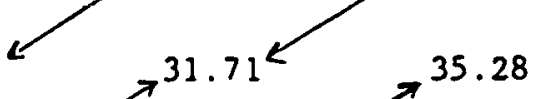

$16^{\prime \prime}$

27.46

32. 11

$17^{\prime \prime}$

31.00

36.25

41.51

$32.31 \%$

36.40

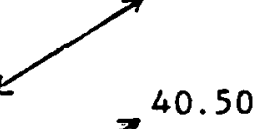

$18^{\prime \prime}$

34.75

40.64

46.53

52.42

58.31 
The small crown of a large volume tree is often an indicator of an exceptional wood producing factory. Ability to convert minimal amounts of radiated energy into wood biomass warrants the further investigation of the full potentiality such a tree may possess as part of a clonal plantation, and as a parent tree for tissue culture propagation.

Height is an overall consideration in the selection process. The presence or absence of competition influences height, making it a more difficult perimeter to judge. Given the choice between a tall, straight, small crowned, large diameter tree or a short tree exhibiting the same qualities, we select the taller tree because of its greater volume.

These selection guidelines were made without any knowledge of the modest number of select trees we might find available at the Grace (sand tailings) and Agrico (overburden) plantings. The guidelines of choice included three steadfast criteria: (1) minimum dbh of 9 inches $(22.86 \mathrm{~cm})$; (2) not forked; and (3) straight stem.

\subsubsection{Selects--Number and Location. After these guidelines} were adopted, a thorough survey of the plantations were made. Results of the survey reduced the cumulative number of candidate trees to 15 at Grace and 23 at Agrico. A reevaluation of both stands added 8 more trees at Grace and 13 at Agrico. These candidate additions were made to provide more genetic diversity. To insure a minimum of compromise from our original criteria, those trees initially selected are further classified as " $A$ " selects and the second group is referred to as "B" selects.

"A" selects at Grace represent less than 0.25 of 1 percent of the original planting. When " $B$ " selects are added, the combination represents less than 0.4 of 1 percent of the base population. At Agrico, percentages are slightly higher, 0.4 of 1 percent and 0.6 of 1 percent based on original planting. These percentages are considerably lower than the original selections made in the South Florida improvement program. For example, in 1966, $119 \mathrm{E}$. robusta were selected from a base population of $2,304(5.2 \%)$ (Dvorak, et al., 1981). 


\subsubsection{Selects--Induced Sprouting. Successful vegetative}

reproduction of eucalypts is increased by the juvenility of the material to be reproduced. Juvenile material can be obtained in two ways: (1) felling or (2) wounding. Sprouts should be allowed to elongate, and then gathered for production of rooted cuttings or introduction into tissue culture.

Some trees were felled and some wounded at each plantation site. All felled trees were cut with a chainsaw. Stumps were cut at an angle of at least $10^{\circ}$ to insure no rainfall collection on top of the stump which might lead to rotting and 1800 than optiwum coppicing. The height of stumps on the high side ranged from a maximum of 11 inches $(27.9 \mathrm{~cm})$ to a minimum of 5 inches $(12.7 \mathrm{~cm})$. Height on the low side ranged from 7 inches $(17.8 \mathrm{~cm})$ to 1 inch $(2.5 \mathrm{~cm})$. Stump diameters, measured above any obvious swell, ranged from 19 inches $(48.3 \mathrm{~cm})$ to 12 inches $(30.5 \mathrm{~cm})$.

Wounding was done with either a three inch $(7.62 \mathrm{~cm})$ or five inch $(12.70 \mathrm{~cm})$ masonry chisel sharpened to a fine knife edge. The aboveground wounding height ranged from 3 to 4.5 feet $(0.9$ to $1.4 \mathrm{~m})$. This was a height of convenience to minimize kneeling and reaching around the tree. Wounding was done by making a girdling type cut through the bark and cambium layers into the woody portion of the tree. Cuts generally were about 0.25 inch $(5 \mathrm{~mm})$ in width and 0.75 to 1.0 inch (18 to $25 \mathrm{~mm}$ ) in depth. There has been no evidence of crown discoloration, leaf loss, or any other indicators of tree mortality associated with the wounding. However, wounding can be too shallow. A possible effect of deep wounding could be structural weakening of the tree contributing to wind damage and fungal infection. No such effects were observed. If wounding occurs when the tree is undergoing rapid growth, the healing process begins almost immediately. Healing can be so rapid that no sprouting occurs. 
An additional assessment of sprouting entailed wounding by chainsaw. A $0.25+$ inch cut $(0.63 \mathrm{~cm})$ was made through the bark and cambium layers into the woody portion of the tree. Care should be taken. to avoid cutting too deeply or the tree will fall and leave a damaged stool. This method was efficient and induced sprouting in 17 days or less. See Table 6-2 for cutting and wounding data relative to sprouting.

Deep wounding at Agrico, if it occurred, was only happenstance. Deep wounding at Grace was planned. The 100\% sprouting of deep wounded trees at the Grace plantation reflects the need for severe wounding.

Original, but sketchy information suggested that sprouting is induced by wounding if the flow of auxins is restricted for up to thirty days (G. Meskimen, pers. comm.). A method thought to block auxin flow was the insertion of many plastic cards into the wound in a fan type arrangement. Our earliest efforts at wounding included the use of several types of artificial blocks such as plastic cards, rubber bands (when cut $14 \times 5 / 8$ inches $/ 36 \mathrm{~cm} \times 1.6 \mathrm{~cm}$ ), butyl rubber and Scotty's Latex Korker.

Our experience revealed that: (1) trees sprout with or without induced blocks; (2) even when inserted with the upmost care, all blocks do not remain in place; (3) a wide wound is required to achieve penetration of the cambium layer; and (4) wide wounds do not lend themselves to holding forcign material in the form of blocks. Following our first attempts, no artificial blocks were used. In our opinion deep wounding does not require artificial blockage to induce sprouting. The best months to induce sprouting remaine unknown. Trees wounded deeply in March, April and July all sprouted. There may be a seasonal advantage for wounding, but more research is needed to determine an optimum time for quantity vigor, suitability for placement into culture, and ultimate plantlet performance. The original plan to spread the felling and/or wounding over a six month period was aborted because of an immediate and high priority demand for more select vegetative material to go into tissue culture and rooted cutting experiments. 
TABLE 6-2

\section{Analysis of Select Sprouting -- \\ Felled Versus Wounded}

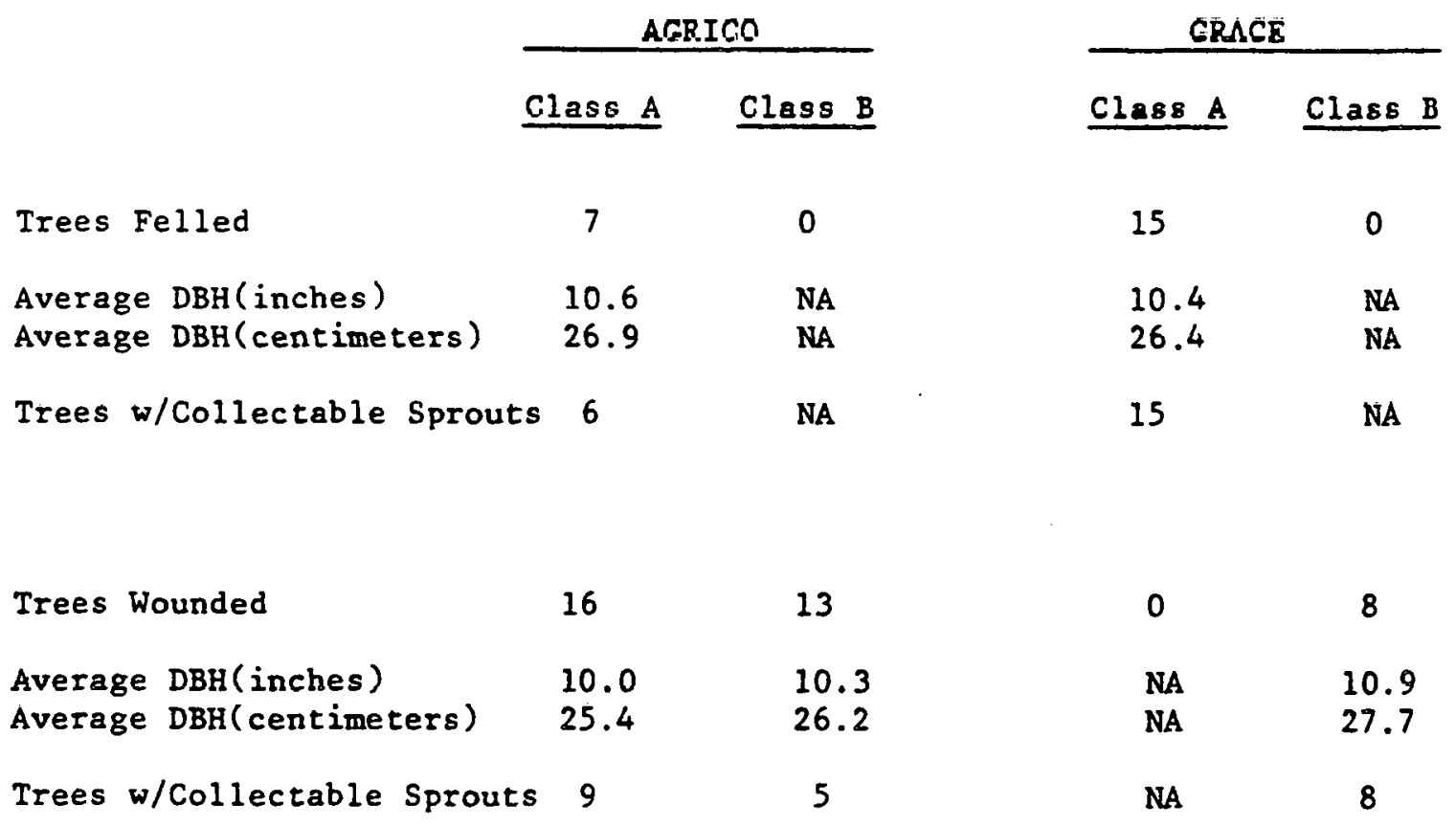


6.3.4 Juvenile Material Management. Stumps and wounded trees subsequently were managed for the continuing production of juvenile vegetative material. As sprouts elongated to approximately three feet $(1 \mathrm{~m})$, they were cut back to a minimum of 10 nodes, or about 12 inches $(30.5 \mathrm{~cm})$ from the base. First observations of juvenility in sprouts of $E$. camaldulensis includes stem squareness, an ephemeral characteristic. As sprouts elongate with growth, this squareness rapidly disappears. The significance of square stems to the suitability of juvenile material for tisgue culture and/or rooted cuttings requires further study, since success depends on the degree of rejuvenation of the parent tree or stool as a continuing donor of vegetative material as well as the response of the cuttings in the laboratory and nursery. 


\subsection{MAINTENANCE AND MANAGEMENT}

The basic thrust of the Florida eucalypt plantation manager must be to operate at a profit. The manager must weigh the expense of each cultural practice and expertly weave it into achieving his overall goals. Certain natural occurrences can be mainpulated by management; but, some acts of nature are uncontrollable. The manager needs to recognize those things he can control and determine the rnst effootivcress of lite pussible manageueul practices.

7.1 Fire Protection. Maintenance and management of the eucalypt forest through its first rotation (6-8 years) will include fire protection by initially installing firelines as required, then replowing, discing, or harrowing the established lines on an annual basis. Based on current Florida Division of Forestry charges of $\$ 19$ per hour, and an estimate of two miles per hour (Mark Hebb, pers. comm.), fireline plowing costs are estimated to be about $12 c$ per acre per year $(30 c / h a)$.

Fireline plowing (new or renewed) chould be pexfurmed at the conclusion of the normal Central Florida rainy season and prior to first frosts which escalate fire danger. Short rotation eucalypt biomass foresț potential.1y are low risk hazards to catastrophic wildfire; however, the shallow lateral root system of the trees could be severly damaged by a slow moving ground fire. Schory (1960) considered Florida eucalypts to be vulnerable to fire, but also observed that fire-damaged trees coppiced readily.

The overburden plantation at Agrico was burned on January 16, 1981 by a slow to medium moving wildfire. There was no apparent damage to trees larger than 3 inches $\mathrm{dbh}(7.6 \mathrm{~cm})$. Damage to smaller trees ranged from a minor set-back to complete mortality. This plantation, vulnerable by virtue of its location near a well-traveled roadway, has been periodically plagued by fire. No estimate can be made of tree and/or growth losses attributable to fire over the years. 
A eucalypt biomass plantation is most vulnerable to catastrophic fire loss during the first 18 months after planting; however, there is little fuel accumulation because of suppression of competing vegetation during this period. Stands vary greatly in the amount of understory vegetation that accumulates fuel later in the rotation cycle. Whole tree chipping reduces the accumulation of slash as fuel. The alleopathic effects from leaf fall may help to prevent fuel accumulation. With the proper maintenance of plowed firelanes, we do not expect fire loss to be a signifieant risk. 
Fires in eucalypt plantations in small to moderate blocks ( 160 acres/ 65 ha) with short-rotation harvesting typically are not catastrophic. Hc er, leaf, bark, and branch litter can accumulate to the point of posing poten..-l fire problems, particularly to young coppice growth. Clonal block plantings and planned road systems lend themselves to low cost fire protection. According to Michel Boulay (pers. comm.), eucalypts are planted in France in buffer strips as a fire protection measure for other forest habitats. Widespread buffer-type plantings of eucalypts along highways and fire breaks could help control wildfires as well as produce woody biomass. Eucalypts are widely planted in California for windbreaks along highway corridors.

7.2 Vegerative Competition. The control of competing grasses and other vegetation within the eucalypt plantation is the single-most important growth-stimulating cultural practice. These controls should be maintained on an "as needed" basis for as long as eighteen months after initial plantation establishment. Control of competing vegetation can be obtained and maintained by mechanical or chemical means, or the two in combination.

Initial site preparation should offer a planting sitp devoid of competing plant growth. If grasses begin regrowth prior to plantation establishment, light discing should be employed. After plantation establishment, herbicide can be applied approximately 2 feet $(0.6 \mathrm{~m})$ on either side of the plants, perhaps in conjunction with discing between rows. This should be done as required and until the eucalypts are approximately eighteen months of age.

Prior to discing, the extent of lateral root elongation between rows should be evaluated. Discs with depth gauges should be utilized and cutting depchs set so as to minimize root damage. This is particularly important in bedded plantings where roots between beds may be at or near the ground 
surface. The frequency of treatment will be influenced by climatic conditions, site quality, plantlet performance, and the initial site preparation.

It is important to choose a chemical herbicide that: ( 1 ) is compatible with eucalypts; (2) is environmentally acceptable; (3) has relatively long lasting effects; and (4) is affordable. Candidates for evaluation and further testing include Roundup, Chipco Ronstar G, Surflan, Devrinol, Paraquat, Sinbar, and Oust, as well as other possibilities.

Oust, a new herbicide undergoing testing and development, was applied to four test plots in June 1981 through a cooperative effort between BESI and Jerry Stephenson (DuPont's Florida Agrichemical Marketing Representative). The plots used for tests contained 1,125 square feet each $\left(104.5 \mathrm{~m}^{2}\right)$, with dimensions of $4.5 \times 250$ feet $(1.4 \times 76.2 \mathrm{~m})$. A survey of the plots two months after treatment revealed complete control of undesirable vegetation with applications of 1.5 and 2 pounds per acre $(1.68$ and $2.24 \mathrm{~kg} / \mathrm{ha})$. We anticipate that no more than three treatments would be required to control competing vegetation over 18 months. However, the cost could be prohibitive.

Present chemical application costs, based on citrus spray equipment rentals ( $J$ im Allen, pers. comm.), are about $\$ 10$ an acre $(0.4 / \mathrm{ha}$ ). Herbicide cost is estimated at $\$ 24 /$ acre $(\$ 59.31 / \mathrm{ha})$ and necessary discing at $\$ 6 /$ treated acre ( $\$ 14.83 /$ treated ha). The total expense for the chemical, its application, and post-application discing is estimated to be $\$ 40 /$ acre ( $\$ 100 / \mathrm{ha})$. 
7.3 Disease/Insects. The proposed Florida eucalypt plantations will require intensive culutral practices typical of monocultures. As species and genetic diversity are compressed to enhance wood production, these reductions favor the spread of disease. A method of reducing susceptibility to epidemic disease may be as simple as clone separations of one mile $(1.6 \mathrm{~km})$, or such other block sizing and distance factoring as may be deemed appropriate. For example, just 16 clonal genetic sources can give a separation of at least 1.5 miles $(2.4 \mathrm{~km})$, while 64 sources ren offer a ceparation of 3.5 miles ( $5.6 \mathrm{ku}$ ).

Diaporthe cubensis has been reported in South Florida eucalypt plantings (Hodges et al., 1979); however, no evidence of the disease was found in North Florida and South:Georgia plantings. The report also indicates that this disease affected $E$. grandis but not $E$. rubusta. Diaporthe cubensis was first reported in Cuba as a trunk cancer on several species of Eucalyptus (Bruner, S.C., 1917). Studies in Brazil show great variability in resistance to Diaporthe cubensis between various species (Hodges, et al., 1976).

Natural ecosystems have yielded resistant genes for incorporation into resistant varieties of important food crops (Leppik, 1970). Disease resistant eucalypt species, or genetic resistance within species may be the foundation upon which to build large scale, high production clonal forests. At the present time diseases or insects affecting eucalypt produrtion in Florida are minor. The forest manager should be aware that the possiblity exists for the endemic situation to become epidemic. Changes in foliage color, high stem mortality, dieback of limbs, and cankers are a few of the obvious indicators. 
7.4 Grazing or browsing damage to newly planted eucalypts is most severe when the tree's root system has not become well established and the crown is within reach of cows. Without perimeter fencing, some damage should be expected if cattle are allowed continued access to the newly planted forest. This damage may only be by trampling if attractive food supplies abound elsewhere; but, it can be catastrophic from actual plant consumption during low forage production periods. In some cases, large trees may be killed by animals rubbing against them; but, the relatively small acutal losses do not justify the expense required to deny cattle access to the forest. Once trees are established, cattle use may even be beneficial. There are no data available to evaluate the relationship.

Small experimental plots are an exception and should receive protection from cattle on a year-round basis.

7.5 Wildiffe. In the native eucalypt forests of Australia there are a variety of habitats which lend themselves to use by a wide range of native species, including the famous koala bear. The eucalypt forest, as introduced into Florida, will provide habitats initially suitable for sustaining and encouraging wildlife use. This is a situation which may be similar to much of the Australian forest where available food is scarce and animal populations are low (Cremer, 1969). Even the koala, which can consume 2.2 pounds ( $1 \mathrm{~kg}$ ) of Eucalyptus leaves per day (Ride, 1970), is nut considercd a earious pest. Only on rare occasions will they defoliate and perhaps kill trees (McNally, 1957).

The Polk County eucalypt plantings show no visual evidence of stress caused by coexistance with native wildlife. The Glades County plantings show some browsing damage by deer on the outer perimeter of block plantings, as well as antler rubbing. It is reported that a small experimental planting near New Smyrna Beach has been severly damaged because of browsing by deer (Dixon, pers. comm.). The forest manager should be alert to the possiblity of potential damage and take appropriate action when required. 
7.6 Cold. Field examinations of the Polk County $E$. camaldulensis plantings (Agrico and Grace) on February 1, 1982 revealed that the severe freeze of January 11-12, 1982, when temperatures dipped to the teens and low 20's for up to 6-12 hours, caused little damage. The young tender coppice growth resulting from cutting or wounding select trees and managed by BESI as a source of juvenile material from March to late October 1981 suffered almost negligible damage. In most cases, sprouts from felled and/ or wounded trees had grown 3 to 5 feet $(1-1.5 \mathrm{~m})$ since the last collection of juvenile material in the fall of 1981. Obvinus rnld damago oonoioted nf slight leaf burning of the Lup six Inchés $(15 \mathrm{~cm}$ ) only, of most coppice shoots examined.

The wounded and other standing trees in the plantations showed only minor damage at the very tip end of branches, with undamaged flowers occurring about 12 inches $(30 \mathrm{~cm})$ from branch ends.

E. tereticarnis at the west and south sides of the Grace planting and on the north side of the Agrico planting showed a 50 to 75 percent leaf burn, but no immediate evidence of wood damage.

The same cold which reached $22^{\circ} \mathrm{F}\left(-6^{\circ} \mathrm{C}\right)$ and lower in Glades County caused severe bark and cambium damage to most stems and branches less than two inches $(5 \mathrm{~cm}$ ) in diameter, and probable damage to stems and branches up to four inches $(10 \mathrm{~cm})$ in diameter. Except for a very few individual stems, $E$. grandis and $E$. robusta plantings in Glades County were totally browned by the cold. The $F$. camaldulensics seed orchard on State Road 74 was virtually untouched by the same cold. Some scattered browning of leaves was observed during a field trip to the area on February 2 , 1982. It is apparent that $E$. camaldulensis offers a tolerance to cold not available from $E$. robusta or $E$, grandis. The cold tolerance of E. camaldulensis, in conjunction with its growth performance in Polk County, enforces its selection as BESI's species of choice. 


\subsection{Drought. Central Florida exhibits definite long-term}

weather patterns. Dry in the spring, wet in the sumer, and alternately wet and dry in the fall and winter, depending on frontal activity.

BESI has considered the undeniable advantage of irrigation and weighed it against the exorbitant cost of watering the forest. Irrigation systems used by the citrus industry range from $\$ 750 / a c r e(\$ 1,850 /$ ha $)$ for low volume drip or mist types to $\$ 1,000$ and up/acre $(\$ 2,470+/ \mathrm{ha})$ for high volume overhead irrigation. Watering by truck, even if at a modest cost of $\$ 20$ per hour and a high watering volume nf four trees per minute, would represent a cost of $\$ 72 /$ acre $(\$ 180 / \mathrm{ha})$ each time plants were watered. Irrigation is not practical or economically feasible.

Except for small experimental plantings, the cost of irrigation is prohibitive using any system now available. Planting should be performed during those times of the year when prior records indicate rainfall adequate for plantlet establishment can be expected. Cloning of drought resistant trees is highly desirable for spring and winter plantings.

\subsection{Access. Access to the forest through a well planned system} of roads, benefits almost every segment of the forest management plan.

In the event of fire, the rapid movement of firefighting equipment to the fastest moving part of the fire can often mean the difference between minimal or catastrophic losses. The eucalypt forest is not likely to burn with the intensity or speed of some other forest types; but, retaining the capacity for early arrival at the fire remains extremely important.

The frequency with which roads cut through the forest facilitates harvesting, inspection for disease, and the general day to day attention the forest manager and his staff need to furnish the forest to promote its well being and profitability. 
The easy access and frequency of roads does provide some potential problem for trespass, vandalism, and wood theft; however, the capacity for close surveillance inherent to a good road system outweighs problems posed by theft, trespass, and vandalism.

Consideration of all forest management activities and the ability to achieve the predetermined goal of profitability at harvest, will determine road frequency. Road construction costs need to show a return through increased yields or lower per unit costs, 


\subsection{HARVESTING}

8.1 Background. Large industrial users of wood select independent contractors to furnish woody raw materials. Wood sources include privately owned, publicly held, and company controlled lands. The pulp and paper companies use a dealer/producer harvesting operation, where dealers contract with large companies to furnish a certain volume or weight of wood on a regular basis, subject to periodic adjustments by the company. The dealer, in turn, has a number of independent producers who cut and deliver to a specific site a certain amount of product on a regular basis, usually weekly. Delivery sites may be rail sidings, wood concentration yards, or the primary mill site. Distance to the mill from the forest dictates the mode of raw materials transport. Generally, as the cost of fuel and labor increases, the distance that wood can be delivered economically by truck to the mill decreases, and/or the size of trucks and wood loads increases.

Harvesting scenarios can be as numerous as the various types of equipment available, operational or prototype. Such equipment is currently undergoing rapid evolution with the state-of-the-art advancing dramatically each year. Thus, it would be unwise to select any one specific method and loose the flexibility of change when faster, more economical equipment arrive on the scene.

The first eucalypt energy plantations will not be ready for harvest until 1989-90. Every harvesting system must perform four separate activities beginning with the standing tree in the forest and ending with the delivery of the tree to the processing plant. These activities are: felling, skidding, yarding, and hauling.

\subsubsection{Felling. Felling is the cuttiug or shearing of} individual trees. The most widely used felling equipment is the chainsaw, as well as the most hazardous to the workforce. For smaller trees ranging up to $30^{\prime \prime}(76.2 \mathrm{~cm})$ at ground level, shear or scissor type feller bunchers on wheels or tracks take much of the sweat and danger out of the logger's labor. The feller buncher is a machine which uses a hydraulic clamp 
to hold the tree while cutting or pinching the stem at near ground level with a mechanical shear, acting like a draw knife or scissors. Machines can accumulate cut trees in bunches up to the basal area accumulation limits of the individual design. When maximum accumulation is reached, the machine then lays severed bunches of stems on the ground in neat convenient stacks. Topography and climatic conditions are two of the limiting factors to be considered when choosing felling equipment. For flat florida terrain, feller bunchers offer a fast mechanical method for felling trees and can operate most of the year in almost all locales.

\subsubsection{Skidding. The skidding operation utilizes four-wheel} drive, rubber-tired skidders to move the stacked trees or logs to central loading points. In some cases, as dictated by either terrain or climatic conditions, steel tracked crawlers or draft type animals may be employed in the skidding operation. Skidders usually move more than one $l o g$ or one tree at a time. This is determined by individual manufacturers specifications which usually measure capability in tons and/or holding capacity in square feet or meters. The butt ends of logs or trees to be skidded are held up off the ground by a steel cable or hydraulic grapple arm mounted at the rear of the skidder on a stationary or moveable " $A$ " frame type arrangment. Only under the most adverse logging conditions would any type other than a rubber-tired skidder be considered for our Florida biomass operations.

\subsubsection{Loading or Yarding. After logs or trees are relocated}

by the skidder to the central loading point, they are readied for shipment to a wood concentration yard or the process plant wood storage area. In a fuelwood or wood to methanol operation there will be no waste. All wood energy will be utilized. Trees will be limbed and topped to conform to maximum road hauling limits and the stems loaded on large trucks for delivery to the concentration yard or plant. The balance of the tree ( 1 imbs and tops) can be chipped and blown into covered trailers by whole-tree chippers. Whole tree chippers are mobile and can move to various loading or yarding sites and quickly set up for operation. Most whole tree chippers have a 
grapple on the end of a flexible knuckle boom which can reach out, grasp, and place wood to be chipped onto a motorized conveyor. This conveyor has pressurized rollers to hold and feed the tree parts to high speed cutting knives that reduce the wood to chips up to 4 inches $(10 \mathrm{~cm})$ in size.

\subsubsection{Hauling. Chips are transported by enclosed or} covered tractor-trailer vans to the process plant wood chip storage or utilization area. The delimbed whole trees may be hauled by conventional logging trucks or tractor-trailers. A combination of the loading operation with hauling could be the lopping off of tops and branches (assumes a clear bole to maximum legal hauling lengths) with a rotary cut-off saw. The saw can be a separate unit or an auxillary attachment to other required rolling stock. The lopped tops and branches should end up in convenient piles at the rear of the $\log$ truck. The mobile chipper will pick up and chip this material leaving the forest site free of slash or waste material which could either slow or preclude coppice regrowth or increase potential fire danger.

Hauling will be limited by height, length, and weight of the load. Florida's maximum legal gross weight per transport unit is 80,000 pounds $(36,287 \mathrm{~kg})$, unless a lessor weight is stipulated. Maximum legal length from the front bumper of the tractor to the rear of the load is 55 feet $(16.8 \mathrm{~m})$, or 65 feet $(19.8 \mathrm{~m})$ with a special annual blanket permit. Special permits for individual trips may be issued for even longer loads. Height limits are generally less than 14 feet $(4.3 \mathrm{~m})$; but, they are controlled by the height of obstructions along the travel route and gross weight of the load. Log trailers loaded butt first probably cannot exceed weight limits and stay within maximum underpass heights. According to E. Cremer (pers. comn.), it is possible to carry 35 to 37 tons (31-3/4 to $33 \frac{1}{2}$ tonnes) by loading half the butts toward the truck cab and the other half toward the rear of the log trailer. If all travel is to be over private roads, weight limits do not pertain and the main consideration may be breaking down the road through excessive weight. 
8.2 Wood Storage on the Plantation. There are advantages to storing cut stems on the plantation. Under this harvesting scenario the tops and branches would be chipped and sent to the plant while the stems would be stockpiled at planned loading sites within the plantation for a period of time, perhaps for 3 to 6 months. Most of the green wood's moisture would be released by the felled stem. Reduction in wood moisture increases fuel effeciency, reduces hauling costs of raw materials, and increases wood volumes which can be transported as single load increments, yet maintaining legal over the road weight limits. These advantages should more than offset the additional cost nf haniling the stems twice at the plantation site.

In the case of green wood with a 50 percent moisture content, 40 tons of green wood, consisting of 20 tons water and 20 tons wood, can not be hauled as a single load. If wood is dried to a 25 percent moisture content, then the same 20 tons of wood contains only 6.6 tons of water and a 26.6 ton load could be legally hauled when weight is the only limitation (Figure 8-1). Samples of Polk County Eucalyptus chipped green wood contained approximately 50 percent moisture by weight, while samples of Polk County Eucalyptus felled five months before chipping contained only 13.5 percent moisture. As moisture content decreases the cubie foot volume of wood in a constant weight load increases (Figure 8-2).

Yet another major advantage of in the woods storage of stems would be the reduction in the size of the yard and volume of wood stored at the plant site. The risk of a large fire loss at the plant yard likewise would be diminished. BESI currently intends to store about 50 percent of the harvested stems only in the woods for at least 3 months before transporting them to the methanol plant. 
FIGURE 8-1

Tons of Water as Moisture Content Decreases

(Decreasing Weight)

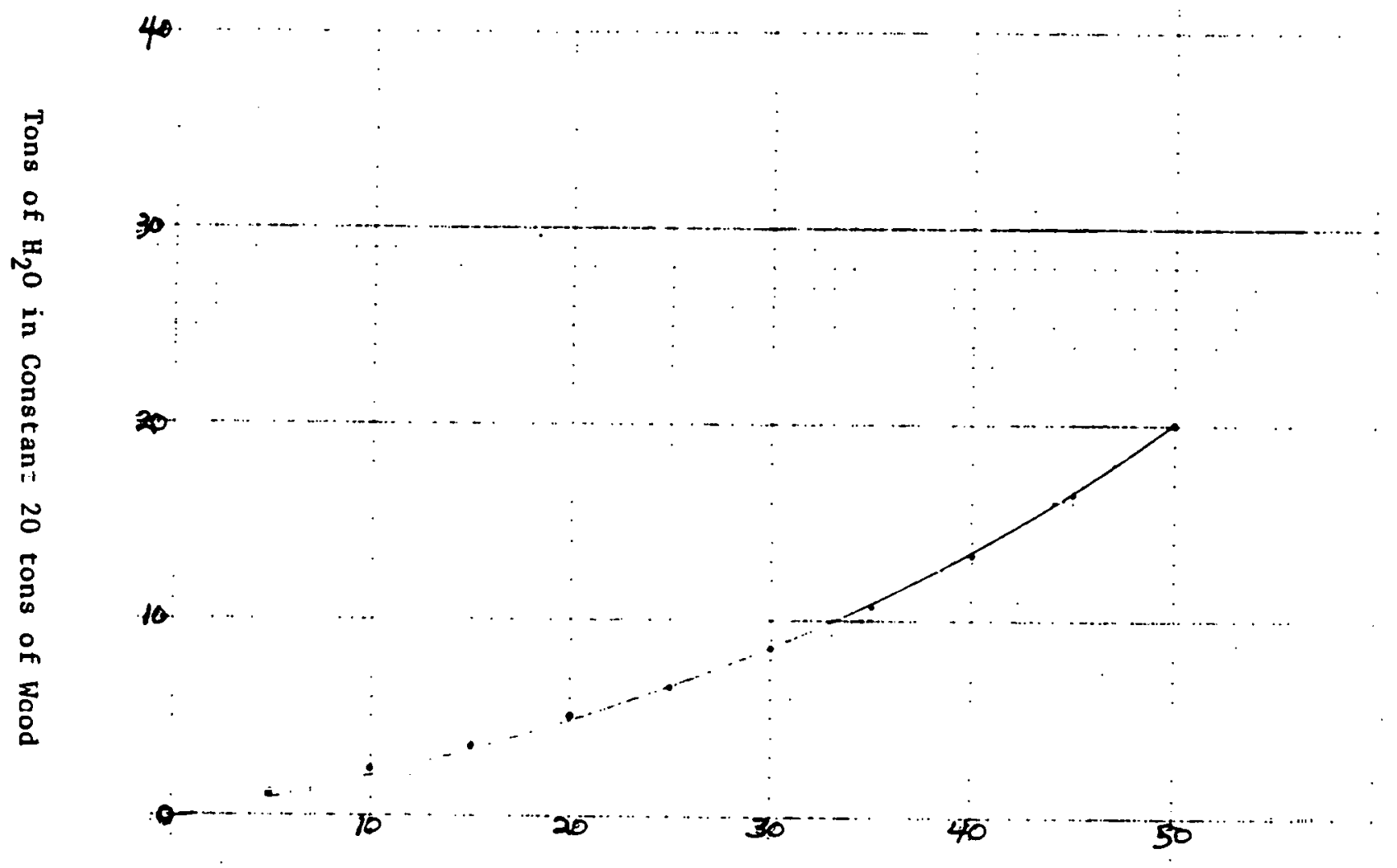

Moisture Content of Wood in percent. 
FIGURE 8-2

Cubic Foot Increase as

Moisture Content Decreases

(Constant Weight)

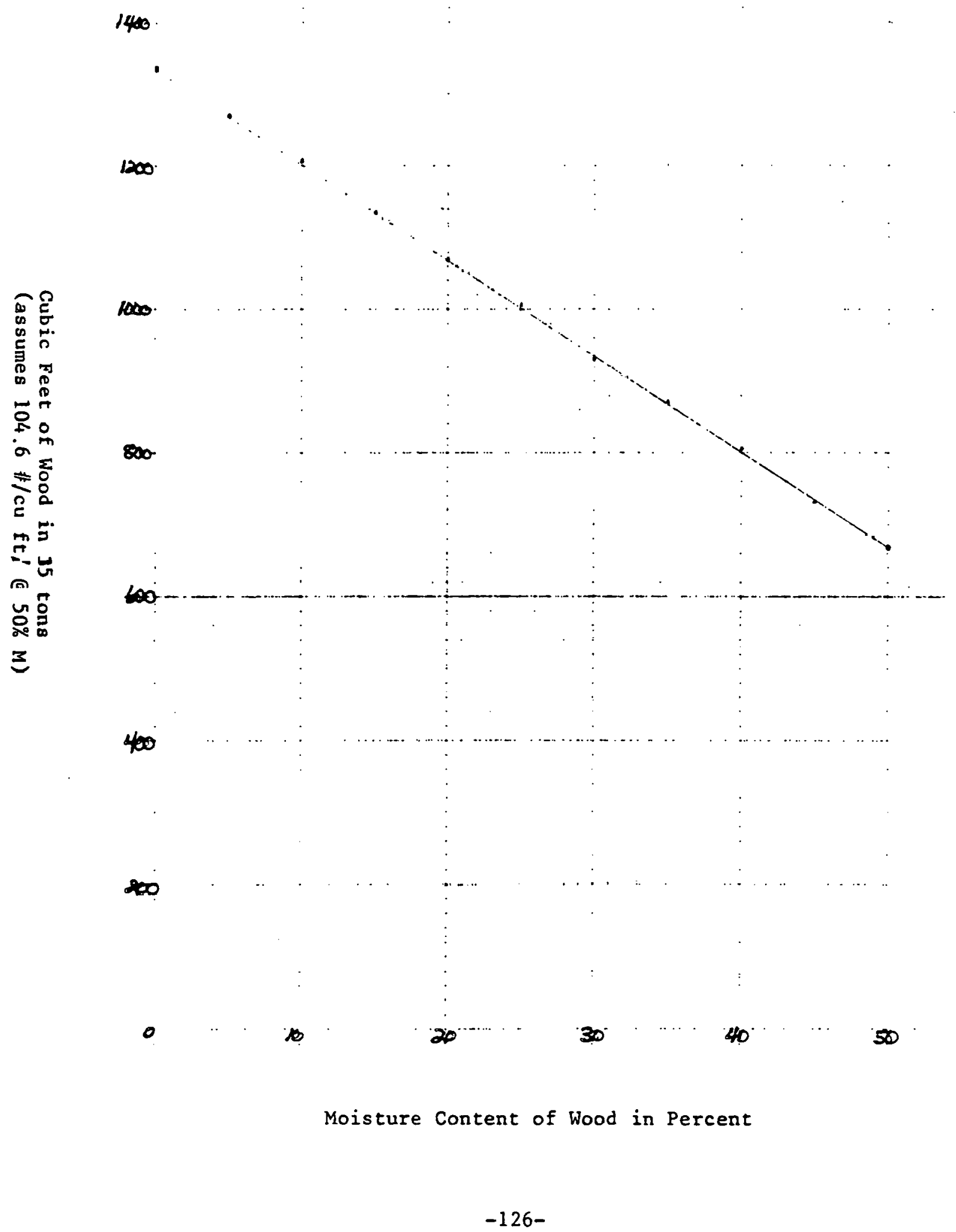




\subsection{Logistics of Delivering Wood to the Plant. This analys is}

assumes that:

(1) 65 percent of the wood required for plant operation will be in the form of whole tree logs,

(2) 35 percent of the feedstock will arrive as chips derived largely from limbs and tops,

(3) the plant requires an estimated 6,000 tons of green wood per day.

Daily plant consumption will be 3,900 tons of whole stems and 2,100 tons of chips. There will have to be 156 loads of logs and 106 loads of chips delivered each day, based on 240 delivery days per year and the use of standard transport operating within the legal limits. In the plant yard storage of stems will range between 1,500 and 3,000 truck loads, a 10-20 day supply.

If we assume an average road speed of 35 miles per hour, 20 minutes to load and unload log trailers, and 35 minutes to load and unload chip trailers, then the distance from the loading point in the forest to the unloading or utilization point at the plant cannot exceed 12 miles. This also assumes that 108 trucks will cycle 10 times and chip trucks 8 times on a daily basis. To operate from a further distance would require some combination of: (1) larger trucks, (2) increased average road speed, (3) reduction in loading and unloading time, (4) more trucks, or (5) rail transport. Nineteen $\log$ truck prime movers yields an 82 percent efficiency rate, while 13 chip truck prime movers yield and 81 percent efficiency rate. This efficiency rate would allow for an approximate 20 percent downtime of vehicles and maintain the necessary equipment to $10 g$ the mill. A higher effeciency rate would require less equipment. 
To process at the plant a total of 156 loads of logs requires 1,560 minutes of unloading time and necessitates three or four plant unloading points. The 105 loads of chips will take 2,625 minutes to unload and requires six unloading points at the plant.

If 261 separate loads of wood enter the plant on each of 240 scheduled delivery days, then one truck enters the plant every 2.5 minutes during a 10 hour work day. This is achallenging exercise in the transport of large quantities of material. Transport by rail, or a large enough site to contain the methanol plant and a preponderance of the plantation acreage in close juxtaposition, would greatly modify the above logistics. On-site movement of wood can be accomplished with much higher payloads in specialized vehicles that could not travel the public highways.

\subsection{Transportation Alternatives. The use of concentration yards} removed from the plant site other than on the plantation storage may be a viable alternative. Advantages of concentration yards include additional stock piling facilities for wood; a local marketplace for wood accessible to small, occassional purveyors of wood; and a permanent, mechanical, and rapid unloading point. While any transloading is an additional cost factor, the cost usually can be carried by both buyer and seller when advantageous to both.

Wood transported to a rail siding usually is the least efficient, most expensive, and most physical because mechanical unloading equipment is not usually available and hand labor is required. Except for rare instances, wood loading at rail sidings has been done by small producers cutting wood from small isolated tracts. The wood generally has been loaded by hand onto a smell truck, then unloaded and stacked by hand on the rail car. The Seaboard Coastline freight office in Lakeland has no knowledge of 
any loading of wood at a rail siding in the last several years other than at mechanized woodyard locations. Suck experience with rail transport of wood in Florida has little relevance to the methods that would be employed to maximize efficiency if rail should prove to be an economic mode for moving wood to the plant. Wood transported to the primary mill by truck normally has been the most efficient and least costly since transloading is unnecessary.

The region is well-traversed by roadways and rail lines. These existing facilites are adequate to perform the necessary task of wood transport following harvests. However, it is anticipated that trafficability will be slowed down in those areas that currently are subject to congestion. A major problem could surface where transportation routes, particularly highways, converge at the methanol facility. Adequate lead time will be available for expansion and upgrading of existing transportation facilities where needed. 
8.5 Feedstock Ownership. Most large users of wood own a substantial portion of the wood required to sustain sontinuod, uninterrupled opetaliuns The southera lased pulp and paper companies usually own in fee or control Lhrough long-term leases (66-99 years) at least 60 percent of their foreseeable merchantable and growing stock requirements. As interest rates increase and land values rise, longterm leases for both the leasee and the leasor take on added attractiveness. Leases can be a fixed or escalating cash payment for a specific number of years, or a lesser cash payment and a portion of net or gross proceeds at the time of harvest. The landowser usually has some sort of minimum guarantee. Through ownership, or at least long-term control, large wood users can arrurately forcenot long-range raw material costs, make definitive management plans for harvesting and planting to insure long-term continuing sustained yields. There also are significant tax advantages for the wood user in growing and supplying the feedstock, particularly for the conversion of biomass to a gasoline substitute like methanol. BESI intends to be a major eucalypt producer.

8.6 Harvest Costs. When considering harvesting costs, for the purpose of simplicity, we include costs from the cutting of the wood to the srockpiling at the piant. Harvesting costs include equipment purchases or rental, direct and indirect labor costs, transportation costs to the primary. point of use, and interest charges for equipment. 
Wood harvesting systems vary from almost entirely hand labor to almost total mechanization. Generally, as hand labor decreases, productivity increases and per unit costs decrease. These cost reductions occur in spite of large front-end expenditures allocated to the initial purchase of sophisticated harvesting equipment, its annual maintenance requirements, and periodic replacement. Southern-based wood harvesting operations generally consider an annual work time of 240 days. This will vary by location based on rainfall, road systems, ground conditions, and volumetric requirements to "log-the mill".

8.7 Harvesting Methodology. For our purposes, we have discarded as too labor intensive all logging systems except "whole tree chipping in woods" and "feller-buncher with whole tree (stem) transport to mill". Since we will require in excess of 1.5 million tons per year for plant operation, we must utilize the most labor efficient harvesting systems operational at the time of harvest. Prototype systems under development will be considered as they become operationally available.

Advantages of "whole tree chipping in woods" include complete utilization of the above-ground woody biomass, increased surface area for air-drying, more efficient combustion with less moisture, and ease in handling and transport. Primary disadvantages include removal from the forest of nutrients and minerals in the leaves and twigs and possible spontaneous combustion problems in conjuction with chip storage.

Advantages of the "feller-buncher with main stem transport to mill" method include leaving in the woods nutrients found in the green leaves and twigs. However, the failure to utilize as much as 35 percent of the harvestable atove-ground biomass may be unsound. Theretore, the grower of the woody biomass should, from an economic standpoint, utilize whole tree chipping methods, or some combination of methods which moves the entire biomass growth from the woods to the mill. 
A combination of whole tree logging in conjunction with chip harvesting of limbs and tops will: (1) allow total above-ground biomass utilization; (2) reduce the requirements for chip storage at the primary plant site, since less than 35 percent of the volume by weight will be in the form of chips; (3) reduce the hazard of spontaneous combustion by keeping the chip pile to smaller, more manageable proportions; (4) reduce overall capital expenditures for harvesting equipment; and (5) allow the bulk of the above-ground woody biomass to enter the plant processing system at the lowoot coot. Indeted, thips may be fen Afrectly finto the plant and not stockpiled except for periods of shut-down and when deliveries exceed consumption.

While no new harvesting equipment technology is necessary, some innovation on the part of the harvesting organization will be required. limbs and tops will need to be wind-rowed at the plantation periphery. Placement should be such that neither the wind-rowed piles nor their conversion to chips interferes with the coppice regrowth of the stand. Delimbing gates, cutoff saws, chainsaws, axes, nt a romhination of any or all of these devices may be required for the cost effective processing of 1 imbs and tops.

Company owned harvesting equipment run by company employees has not been ruled out at this time. Because of the Central Florida location and the lack of experienced woods workers, recruitment and training of a skilled harvesting workforce will be necessary. Most pulp and paper companies have used company employees to run equipment while working as the woods force to "log the mill". For a variety of reasons, company harvesting operations generally have been unsuccessful. BESI will carefully examine harvesting options when eucalypt stocks are ahout one year from moturity in 1988-89 und make the necessary and prudent decisions at that time as to details of the harvesting operation. Tax laws and depreciation allowances in effect at that time may be the overriding determinant in the decision making process. 


\subsection{EUCALYPT BIOMASS PRODUCTION ESTIMATES}

9.1 Background. Our woody biomass production predictions are based on growth studies of the previously described Polk County Eucalyptus camaldulensis plantations on sand tailings and overburden. A production study of $E$. grandis and $E$. rabusta by Meskimen (1979) offers a base for projections of production for flatwoods.

Estimates found in Table 9- $i$ are based on the earliest available data and use a volume formula which reflects only "merchantable volume" (pulpwood). Our literature search disclosed no satisfactory formula which equated a standing eucalypt to its total above ground biomass volume. The estimate of 5.9 cubic feet of wood weighing 613 pounds $\left(0.17 \mathrm{~m}^{3}\right.$ and $\left.278 \mathrm{~kg}\right)$ understates the true volumetric measurement of the total above ground biomass; but, it does accurately predict average tree weights based on dbh, total height, and site quality parameters.

The purchase of wood thirty years ago depended almost entirely on ocular estimates, or a series of time consuming measurements. Today, wood is purchased almost entirely on the basis of weight. In some cases, measured weight is converted to a locally acceptable unit of measure. In Florida, the cord is a standard term used by purchasers of pulpwood; however, the weight of a cord varies by both geographical location and species. For instance, the weight factor for South Florida slash pine is greater than that for North Florida slash pine. In some cases, a cord also varies by volumetric measure. Citations in the literature range from 80 cubic feet $\left(2.3 \mathrm{~m}^{3}\right)$ to 92 cubic feet $\left(2.6 \mathrm{~m}^{3}\right)$ when describing a cord reduced to solid wood content. 


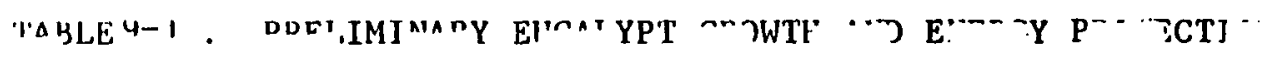

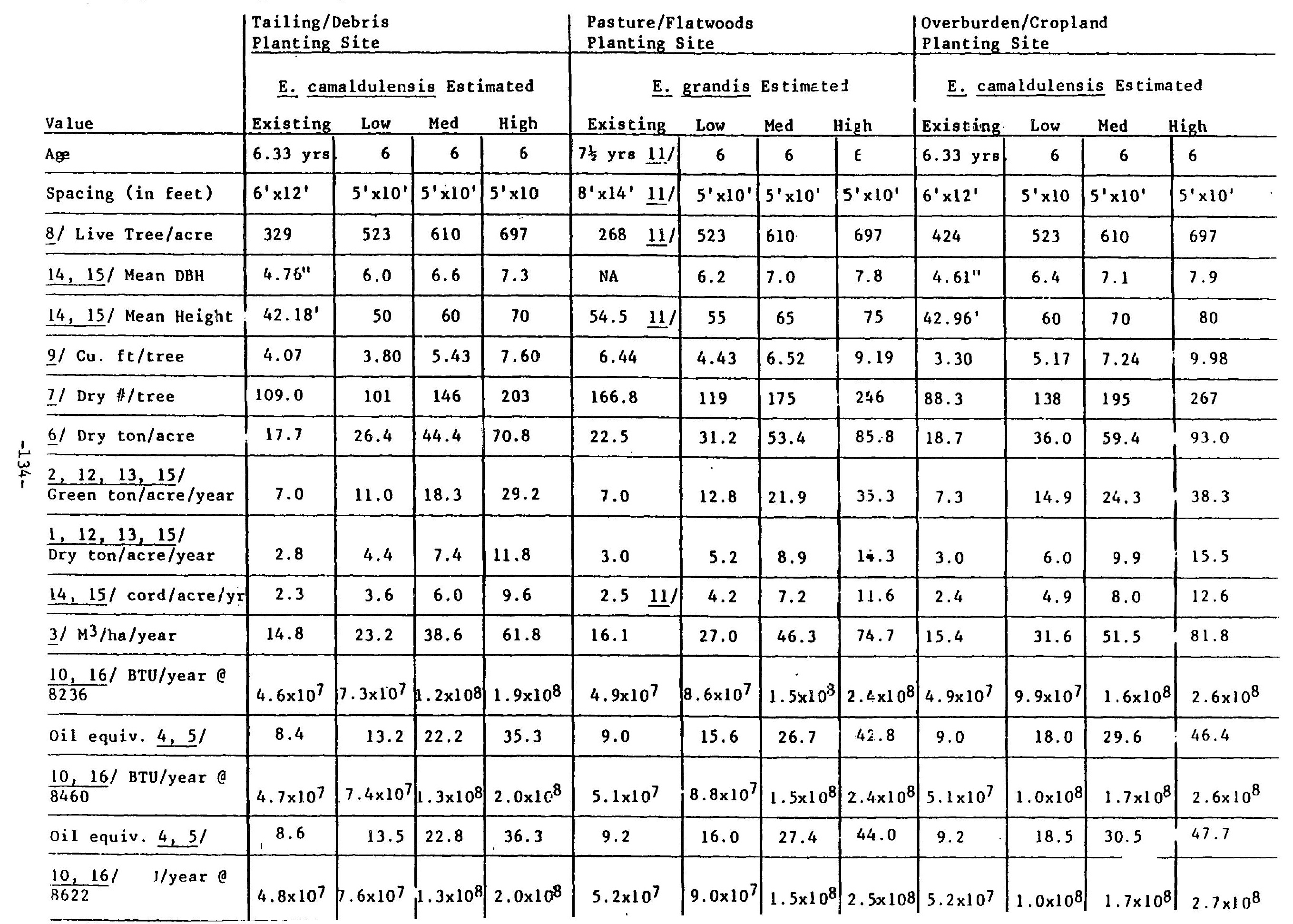


9.2 Projections. Production predictions (Table 9-1) have been made for three different soil types found in Central Florida: flatwoods; sand tailings; and overburden. Each of these soils was divided into low, medium, and high growth ranges. Predicted growth increases are based on: (1) an increase in planting density from a previously recomended density of 605 stems per acre $(1,495 /$ ha $)$ to 871 stems per acre $(2,152 /$ ha); (2) volumetric increases through vegetative propagation of genetically superior materials; (3) improved site preparation and control of competing vegetation for eighteen months; (4) fertilization as appropriate to stimulate growth and avoid phosphate toxicity; and (5) increased survival.

Predictions of the growth potential of $E$. camaldulensis range from a low of 11 green tons per acre per year $(24.7 \mathrm{gt} / \mathrm{ha} /$ year $)$ on the poorest soils under poor conditions to 38.3 green tons per acre per year $(85.9 \mathrm{gt} /$ ha/year) on the best soils under the most favorable conditions. Based on a seven year rotation, production is estimated to range from 77 green tons per acre! $173 \mathrm{gt} / \mathrm{ha}$ ) to 268 green tons per acre ( $600 \mathrm{gt} / \mathrm{ha})$. Table 9- 2 compiles these data.

9.3 Weights and Volumes. A sample of three trees, six, seven and eight inch $\mathrm{dbh}(15.2,17.8$, and $20.3 \mathrm{~cm})$, varying from 50-60 feet (15.2$18.3 \mathrm{~m}$ ) in height, was cut flush to the ground and weighed. Stems, up to an approximate three inch $\mathrm{dbh}(7.6 \mathrm{~cm})$ top, were weighed separately from limbs and crowns. Based on actual weight measurements, the mean weight green of these three six, seven, and eight inch $(15.2,17.8$, and $20.3 \mathrm{~cm}$ ) $\mathrm{dbh}$ trees, 50,55 , and 60 feet $(15.2,16.8$, and $18.3 \mathrm{~m})$ tall, was 613 pounds $(278 \mathrm{~kg})$. The average stem weight was 500 pounds $(227 \mathrm{~kg})$ and the average weight of the 1 imbs and crown was 113 pounds $(51 \mathrm{~kg})$. Approximately 18 percent of the total average weight was in limbs and crown (Table 9-2). 
TA3LE 9-2

\section{TREE KEIGHTS (GREEN)}

\begin{tabular}{|c|c|c|c|c|c|c|c|c|c|}
\hline \multirow{2}{*}{\multicolumn{2}{|c|}{ DBH }} & \multirow{2}{*}{\multicolumn{2}{|c|}{ HEIGHT }} & \multirow{2}{*}{\multicolumn{2}{|c|}{ VOLUME }} & \multicolumn{4}{|c|}{ ACTUAL WEIGHT } \\
\hline & & & & & & \multicolumn{2}{|c|}{ STEM } & \multicolumn{2}{|c|}{ CROWN } \\
\hline inches & centimeters & feet & meters & cubic feet & cubic dm & pounds & Eilograms & pounds & kilograms \\
\hline 6 & 15.2 & 50 & 15.2 & 3.86 & 109.3 & 340 & 154.2 & 180 & 81.6 \\
\hline 兄 & 17.8 & 55 & 16.8 & 5.70 & 161.4 & 560 & 254.0 & 80 & 36.3 \\
\hline 8 & 20.3 & 63 & 18.3 & 8.03 & 227.4 & 600 & 272.2 & 80 & 36.3 \\
\hline $7 *$ & $17.8 \%$ & $55^{*}$ & $16.8^{*}$ & $5.86^{*}$ & $166.0^{*}$ & $500^{*}$ & $226.8^{\star}$ & $113^{*}$ & $51.4^{x x}$ \\
\hline
\end{tabular}


Based on data provided by our plant design consultants, Polk County $E$. camaldulensis green wood samples had a moisture content of 50.7 percent. Thus, in a bone dry state, an average stem would weigh 246.5 pounds $(11.8 \mathrm{~kg}$ ), the limbs and top would weigh 55.7 pounds $(22.3$ $\mathrm{kg}$ ), and the total dry above ground biomass weight would be 302.2 pounds $(137.1 \mathrm{~kg})$. If the average tree contains 5.9 cubic feet of wood, then the equivalent of 15.7 trees would be needed to provide one 92 cubic foot cord of wood, and six trees would be needed to provide one cubic meter of wood.

Assuming a mean average production of 22 green tons per acre per year ( 49.3 tonne/ha/yr) and a seven year rotation, the total biomass production per rotation will be 154 green tons per acre ( 345.2 tonne/ ha). 
9.4 Methanol Plant Feedstock Requirements. To produce $100,000,000$ gallons $(378,541,200$ liters) of methanol will require about 4,000 tons $(3,619$ tonnes $)$ of wood per day. Based on an above-ground biomass green weight of 613 pounds $(278 \mathrm{~kg}$ ) for each tree, biomass harvesting requirements would be:

\section{AREA REQUIREMENT}

Plantation
Survival Rate

$70 \%$

$80 \%$

$90 \%$

Aeres Daily

21

19

17
8.7

7.6

6.7
Annua

Acres Hectares

$7,665 \quad 3,175$

$6,935 \quad 2,774$

$6,205 \quad 2,445$

A thirty day start-up wood inventory of 120,000 tons (108,862 tonnes), consisting of more than 2 million cubic feet $\left(65,000 \mathrm{~m}^{3}\right)$, would require storage space of about 3.2 acres $(1.3 \mathrm{ha})$ if wood is piled to a 50-foot (15.m) height, or 6.4 acres $(2.6 \mathrm{ha})$ if stacking height is limited to 25 feet $(7.6 \mathrm{~m})$. This wood inventory storage at the plant site could be reduced substantially by storing cut stems in the plantation for three months.

A typical whole tree logging crew, operating under average field conditions, should produce ten 25-ton (22.7 tonne) loads of wood per day. Using a 240 day annualized harvesting schedule, daily plant delivery will be about 6,000 tons $(5,500$ tonnes) and will require 30 operational logging crews, of 8-10 workers each, assuming an $80 \%$ efficiency rate. 


\subsection{Estimated Costs, Yields, and Gross Revenues. Under typical}

Florida conditions, and todays prices, it is estimated that site preparation, plantlet purchase, and planting will cost about $\$ 500$ per acre $(\$ 1,235 / \mathrm{ha})$. Included in site preparation is the removal of residual stumps, chopping or double chopping surface vegetative materials, discing with a heavy disc, applying 0.5 tons per acre (1.12 t/ha) of ground rock phosphate $\left(\mathrm{P}_{2} \mathrm{O}_{5}\right)$, discing with a medium disc, bedding, applying herbicides, planting, and establishing necessary firelines. The cost of the internal road system is independent of site preparation.

Average yield based on average growth and survival for clonal tissue cultured plantlets is estimated to be 154 green tons per acre $(345 \mathrm{gt} / \mathrm{ha})$ during a seven year rotation. Using a gross value of $\$ 30$ per ton $(\$ 33.07 /$ tonne) for wood chips, which understates present F.O.B. West coast values of \$80-85/BDT (Darr, pers. comm.), provides a gross return per acre of $\$ 4,620(\$ 11,700 / \mathrm{ha})$.

Using an estimated harvesting cost of $\$ 10$ per ton ( $\$ 11.02 /$ tonne), the per acre harvesting cost is $\$ 1,540(\$ 3,805 / \mathrm{ha})$. Harvesting costs will vary by harvesting method employed, distance from the forest to the utilization point, fuel prices and consumption, and the cost of labor and benefits. An estimate of whole tree harvesting costs is compiled in Table 9-3 and an estimate of whole tree chipping costs is compiled in Table 9-4.

By subtracting installation costs of $\$ 500$ per acre $(\$ 1,235 / \mathrm{ha})$ and harvest costs of $\$ 1,540$ per acre $(\$ 3,805 / h a)$ from a gross value of $\$ 4,620$ per acre $(\$ 11,700 /$ ha) we arrive at a gross return of $\$ 2,580$ per acre $(\$ 6,375 / \mathrm{ha})$ over the 7 year rotation from which must be deducted costs for management, purchase or rent of land, interest charges, and return on investment. There are, of course, ancillary financial benefits to be derived from inhousing the site preparation and harvesting operations. Furthermore; a more mid-range, less conservative prediction of green chip market value in 1990 would be $\$ 50 /$ ton instead of the $\$ 30$ value used in this analysis. 
TABLE $9-3$

Estimated Dally (Per Ton) Operating

Costs for Whole Tree Harvesting

Daily Operating Costs

1 Feller Buncher

1 Chainsaw

2 Skidders $w /$ hdy Grapple

$\$ \quad 113.75$

1.75

1 Log Loader/w Cutoff Saw

192.50

2 Prime Movers a $55 \mathrm{c} / \mathrm{mile} / 600 \mathrm{mile} / \mathrm{day}$

3 Log Trailers @ 10c/mile/400 mile/day

113.75

660.00

120.00

1 Hickup

17.50

Miscellaneous tools

3.50

Subrocal $\$ 1,226.23$

Annual Overhead Costs

Depreciation

$\$ 93,743.79$

Interest, Taxes, etc.

Truck Ins., Use Tax, License

$100,000.00$

Bookkeeping, etc.

Legal fees

office expenses

Workmans Compensation

$10,000.00$

$5,000.00$

$5,000.00$

5.000 .00

$24,300.00$

Other labor overhead

$19,440.00$

Total Annual Overhead

$\$ 262,483.79$

Annual Working Days--240

Overhead Cost Per day

Labor/Field Supervisor $\$ 1500 / \mathrm{mth}$

$\$ \quad 1,093.68$

6 persons d $\$ 5 / \mathrm{hr}--10 \mathrm{hr} / \mathrm{day}$

Operating Costs Per Day

75.00

330.00

$1,222.75$

Total Daily Costs

$\$ 2,721.43$

Costs per ton per day (500 T/day)

$\$ 5.44$ 
TABLE $9-4$

Estimated Daily (Per Ton) Operating

Costs for Whole Tree Chipping

\author{
(per day) \\ Daily Operating Costs
}

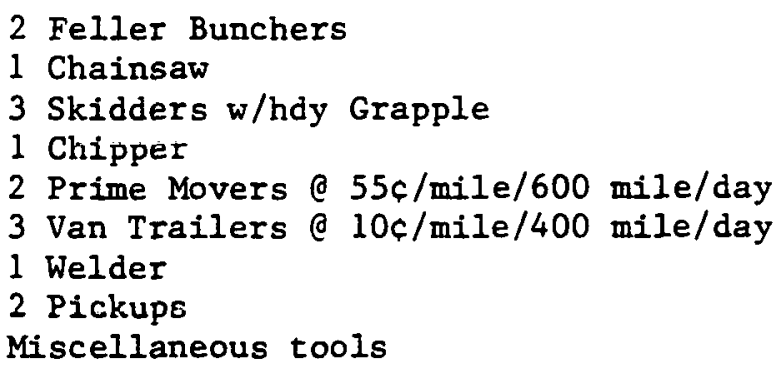

Subtotal

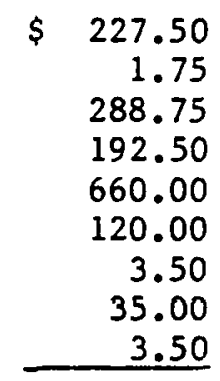

$\$ 1,532.50$

\title{
Annual Overhead Costs
}

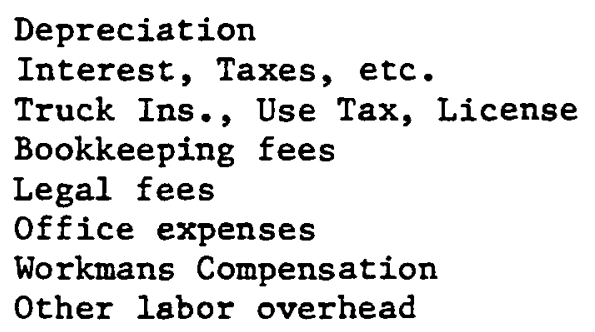

Total Annual Overhead

$$
\begin{array}{r}
\$ 158,361.81 \\
150,000.00 \\
10,000.00 \\
5,000.00 \\
5,000.00 \\
5,000.00 \\
37,500.00 \\
30,000.00 \\
\hline
\end{array}
$$

$\$ 400,861.81$

Annual Workiug Days--240

Overhead Cost Per Day

Labor/Field Supervisor $\$ 1500 / \mathrm{mth}$ 10 persons \& $\$ 5 / \mathrm{hr}--10 \mathrm{hr} /$ day Operating Costs Per Day

Total Daily Costs

Cost per tone per day ( $400 \mathrm{~T} /$ day)
$\$ \quad 1,670.26$

75.00

550.00

$1,532.50$

\$ $3,827.76$

$\$ 9.57$ 


\subsection{SYNOPSIS}

Unbeknown to most of mankind, wood is on the threshold of again dominating the world's energy and chemical markets. Singular reliance on exhaustible and environmentally imperiling fuels hes brought man to near catastrophe. The acid rain crisis will expand to nightmarish dimensions before being brought under control. The greenhouse effect will intensify over the next century before peaking. Global leaders will launch a massive forestation effort, planting trees of all kinds wherever they will grow. These new stocks of wood will feed our fuel and chemical appetites, capturing from coal and oil a major share of the market. As a fringe benefle, the vast new plaulaliuns will decitase soil erosion, create topsoil, increase raintall, store carbon dioxide, and fulfill many of the invaluable other functions of forest ecosystems.

The rapid rise of wood consumption as a fuel is one of the best kept secrets in this era of energy transition. Wood fuel use is skyrocketing in the United States and in many other countries as well. Indeed, there already is a shortage of wood feedstocks, but world forestry inventory methods are so inadequate that the magnitude of the shortages are not appreciated. The world market value of wood can be expected to increase steadily and perhaps dramatically over the long term. Recognition of the world shortage of wood fibers for quality paper production was the underlying basis for Daniel Ludwig's impressive and farsighted Jari project. Deforestation and desertification around the world has depleted forest stocks far more rapidly than the relatively feeble efforts at reforestation compensate for their loss. Even in the United States, the overall annual harvest now is thought to exceed annual growth.

Perhaps the greatest benetit from the oil shortages and high prices imposed on the world by the oil producing countries has been the impetus given to seeking biomass alternatives. Science and technology responded and continues to respond by developing new and effective uses for biomass feedstocks, and especially for wood and its chemical constituents. These 
new technologies will spawn new industries which will create products with economies of scale, and all from renewable organic feedstocks.

It was in this atmosphere of technological innovation that BESI undertook the mission of pioneering a large scale Eucalyptus energy plantation to methanol project. After two years of studying the feasibility of the concept, we are convinced that Eucalyptus offers a fast growing, renewable, woody biomass resource readily adaptable to Central and South Florida's soil and climatic conditions. Based on the best available research, establishment of eucalypt biomass plantations in Central and South Florida is ecologically, environmentally and economically sound, indeed desirable. Brazil has one of the largest eucalypt plantations in the world, some 100,000 acres, where they have produced 18 tons/acre/year in the third rotation! Future yields of 45 tons/acre/year are considered reasonable. Following the guidelines and recomendations set forth in this silvicultural document, relying on plantlets produced by the tissue culture cloning of select trees, we believe Florida yields in excess of 20 tons/acre/ year are possible at the onset. By the end of this decade, Florida eucalypt chips can be expected to sell in markets seeking their fiber, energy, and chemical feedstock properties, for about $\$ 50 /$ ton.

As for benefiting the great State of Florida, we are convinced the full and productive use of under-utilized Central and South Florida lands to grow eucalypts will increase the governmental tax base, create new jobs, encourage and stimulate industrial development, and increase the flow from the spigot of sun-derived energy. 


\section{LITERATURE CITED}

Abelson, Philip H. 1980. Energy from biomass. Science Magazine. 20 June 1980. Vol. 208, No. 4450.

- 1981. Energy and chemicals from biomass. Science. 213(4508). August 7 .

- 1982. Energy and chemicals from trees. Science. 215(4538). March 12 .

Amerioan Chamioal Sogioty 1981.. Biomaoo ao a nonfoaoil fuel naures. ACE Eymposium Eeries 144. Washington, D.C. Donald I. Klass (EU.) 564 PP.

Ashton, D. H. . 1962. Some aspects of root competition in E. regnans. Proc. 3rd Gen. Conf. I.F.A., Melbourne, Australia.

Baker, J.B. and B.G. Blackman. 1977. Biomass and nutrient accumulation in a cottonwood plantation--the first growing season. Soil Sci. Soc. Am. J. 41(3):632-636.

Barney, G.O. 1980. The global 2000 report to the president. Vol. II: The rechrieal report. Council on Env. Quality. U.3. Guv. Pliuliuy nffice. $766 \mathrm{pp}$.

Barnett, J. P.1981. (ed.). First biennial southern silvicultural research conference. Atlanta Conference Proceedings, Southern For. Exp. Sta., Gen. Tech. Rep. So-34.

Berger, Beverly J. 1981. Biomass energy systems program wood energy activities. In: Industrial Wood Energy Forum 81. March. Proceedings No. P-81-31. FPRS. Madison, Wis.

Bevege, D.I. 1976. A green revolution in the high yield forest: rational silviculture or new technology. Aust. For. 39:40-50.

Blakely, W.F. 1955. $\Lambda$ kcy to the cuealypts. Eecond Ed. $359 \mathrm{pP}$. Fui. aul Timber Bur., Australia.

Boden, R.W. 1964. Hybridization in eucalytpus. Indian For. 90(9):581-586.

Boggan, J.A. 1977. How Mead Papers learned to use whole-tree chips for bleached pulp. Pulp and Paper Magazine, December.

Bradley, J.T. 1975. Freeze probabilities in Florida. Agr. Exp. Sta. IfAS. Univ. of Florida. Gainesville, Tech. Bul. 777. 
Brunck, F. 1975. Principal problems connected with animal or vegetable pests in natural forest stands and man-made forests of French speaking tropical counties and North Africa. Second FAO World Technical Consultation on Forest Diseases and Insects. New Delhi. April 7-12.

Bruner, S.C. 1917. Una enfermedad gangrenosa de los eucaliptos. Boletine No. 37. Estacion Experimental Agronomica, Santiago de las Vega, Cuba. 38 pp.

Budiansky, Stephen. 1980. Chemical feedstocks from biomass. Environmental Science and Technology. Vol. 14(6). June.

Bungay, H.R. and R.F. Ward. 1977. Fuels and chemicals from crops. PP. 105-120. In: L.A. Anderson and D.A. Tillman, Fuels from Waste. Academic Press, New York.

Butson, K.D. and G.M. Prine. 1968. Weekly rainfall frequencies in Florida. Agr. Exp. Sta. Unv, of Florida. Gainesville. Cir. S-187. 41 pp.

Butts, Paul M. and Druid N. Preston. 1979. Whole tree chipping...a forestry management tool. Georgia Forest Research Paper. No. 4 . June. Georgia Forestry Commission.

Cameron, D.A. and L.F. Riley. 1981. Site preparation for trailed planting machines: The CFS V-Blade. In: Forest Regeneration. Proceedings of the American Society of Agricultural Engineers Symposium on Engineering Systems for Forest Regeneration. March.

Cameron, J.N. 1980. Plantations and the Brazilian economy. Papers prepared for Austailian Forest Grower. 7 pp.

Carter, W.G. 1974. Growing and harvesting eucalypts on short-rotations for pulping. Aust. For. 36(3):214-225.

Chippendale, G.M. 1973. Eucalyptus of the western Australian Goldfields (and adjacent wheatbelt).

Conde, L.F. and D.L. Rockwood. 1979. Energy plantation potential in Florida. Unv. of Fla. Coop. Ext. Serv. IFAS. Gainesville, FL. p. 2-11. Proceedings: Alternative Energy Sources for Florida.

Couto, H.T.Z. do., H.A. Mello, J.W. Simoes and R. Vencovsky. 1973. Coppice management of E. saligüa. IPEF 7, 115-23.

Cowan, William F. Planting eucalyptus in South Florida. Eucalyptus Handbook for Southern United States. Lykes Bros. Palmdale, FL. In Manuscript. 
Crane, Wilfred J.B. 1972. Fire in the Australian Environment. Fire in the Environment Symposium Proceedings. Denver, CO. May.

Cremer, K.W. 1969. Growth of eucalypts in experimental plantations near Canberra. Aust. For. 36:214-25.

Cremer, K.W., R.N. Cromer and R.G. Florence. 1978. Stand establishment. In: Eucalypts for Wood Production. Hillis and Brown (eds.) pp. 81-135.

Cromer, R.N. 1974. The potential for eucalyptus plantations in Victoria. Eucalypt Seminar Gippsland, Victoria Journal of Science and Australian Tech. Vo. 12(6) May 1975.

Cromer, R.N. 1975. The potential for Eucalyptus plantations in victoria. Jor. of Sci. and Aust. Tefh. 12(6). May.

Cromer, R.N., M. Raupsch, A.R.P. Clarke and Cameron. 1975. The potential for intensive production and utilization of eucalypts in Australia. 29th APPITA Conf. March. Launceston.

Cromer, R.N., E. Williams and D. Tompkins. 1980. Biomass and nutrient uptake in fertilized E. globulus. IUFRO Symposium and workshop on Genetic Improvement and Productivity of Fast Growing Trees. Sao Pedro, Sao Paulo, Brazil. August.

Dawson, D.H. 1976. History and organization of the maximum wood yield program. PP. 1-4. In: Intensive Plantation Culture; Five Years Research, USDA For. Serv. Gen. Tech. Rep. NC-21, Northcentral For. Exp, Eta., Et: Paul, MN.

Dawson, David H., Zavitkovski, J. and J.G. Isebrands. 1980. Managing forests for maximum biomass production. AIChE Symposium Series 75(195).

DeBe1I, D.S. 1970. Phytotoxins: new problems in forestry? Jorn. For. $68: 335-337$.

DeBell, D.S. 1972. Potential productivity of dense young thickets of red alder. For. Res. Note No. 2. Crown Zellerback Corp. Central Research, Camas, Wash.

DeBell, D.S. and J.C. Harms. 1976. Identification of cost factors associated with intensive culture of forest crops. Iowa State Jorn. of Res. $50(3): 295-300$.

DeBel1, D.S., R.F. Strand, and D.L. Reukema. 1978. Short-rotation production of red alder: some options for future forest management. pp. 231-244. In: Utilization and Management of Alder. USDA For. Serv. Gen. Tech. Rep. PNW-70. Pac. NW For. Rge. Exp. Sta. Portland, OR. 
DelMoral, R. and C.H. Muller. 1970. The alleopathic effects of

Eucalyptus camaldulensis. Amer. Midland Naturalist 83:254-282.

Donald, C.M. 1968. The breeding of crop ideotypes. Euphytica. Vol. 17.

Dutrow, G.F. 1971. Economic Implications of silage sycamore. USDA For. Serv. Res. Pap. 50-66. South. For. Exp. Sta.

Dvorak, W.S., E.C. Franklin and G. Meskimen. 1981. Breeding strategy for $E$. robusta in Southern Florida. Presented at 16 th Southern Forest Tree Improvment Conference, Blacksburg, VA.

Ek, A.R. and D.D. Dawson. 1977. Yields of intensively grown Populus: actual and projected. Pp. 5-9. In: Intensive Plantations culture; Five Years Research. USDA For. Serv. Gen. Tech. Rep. NC-21. Northcentral For. Exp. Sta., St. Paul, MN.

Eldridge, K.G. 1978. Genetic improvement of eucalypts. CSIRO Division of Forest Research. Silvae Genetica 27, 5(1978). Canberra, A.C.T. 2600. Australia.

Environmental Protection Agency. 1978. Areawide Impact Assessment of the Central Florida Phosphate Industry. Vol. IV and $X$.

Fege, A.S., R.E. Inmen, and D.J. Salo. 1979. Energy farms for the future. Jorn. For. $77(6): 356-361$.

Filho, V.B.andA.J.A.Zagatto. 1980. Methanol from Brazil. American Chemical Society National Meeting, March 23-38. Houston, Texas.

Florence, R.G. and K.R. Shepherd. 1975. The role of eucalypt forests in wood production. Aust. For. 38:100-16.

Food and Agriculture Organization of the United Nations. 1955. Eucalypts for plantiug. 1rst Ed. (FAO: Rome).

Food and Agriculture Organization of the United Nations. 1975. Pulping and papermaking properties of fast-growing plantation wood species. Rome. December. FO:MISC/75/31. 237 PP.

Food and Agriculture Organization of the United Nations. 1976. Harvesting man-made forests in developing countries. Rome. P. 119.

Franklin, E.C. 1977. Yield and properties of pulp from eucalypt wood grown in Florida. TAPPI. $60(6)$. June.

Franklin, E.C. 1978. Exotics for hardwood timber production in the Southeastern United States. Reprinted from proceedings 2nd Symposium. Southeastern Hardwoods. U.S. Dept. Agric. For. Serv. Southeast. Area S\&PF, Atlanta, GA. 
Franklin, E.C. 1979. Prospectus: Development of tropical forest resources in southern Florida. Prepared for International Forest and Seed Company, Birmingham, AL.

Franklin, E.C. and G.F. Meskimen. 1973. Genetic improvement of Eucalyptus robusta sm. in Southern Florida. Proc. IUFRo Working Parties on Trop. Prov. and Progeny Res. and Int. Coop., Commwl. For. Ints. Oxford: 421-424.

Franklin, E.C. and G.F. Meskimen. 1975. Progeny testing in a eucalyptus breeding program. Proc. IUFRO Working Parties of Progeny Testing. Southeastern For. Exp. Sta. Asheville, 2-4.

Fujii, David M. 1976. The nuuanu eucalyptus planting: growth, survival, stand development after 64 years. Pac. SW For. and Rge. Exp. Sta. USDA For. Serv. Res. Note PSW-318.

Geary, T.F. 1975. Winter planting potential of four oucalypt epecies in South Flurida. Tree Flanters Notes $28(3 \& 4): 14-17$.

Geary, T.F. and George Meskimen.

Seed technology. Southeastern For. Exp. Sta. Lehigh Acres, FL. In: Eucalyptus Handbook for Southern United States. In Manuscript.

Georgia Forestry Commission. 1980. Wood Energy in Georgia. October.

Goes, E. 1967. Culkure do Eucalipto. Lisboa.

Greaves, T., G.J. Armstrong, R.S. McInnes and J.E. Dowse. 1967. Timber losses caused by termites, decay, and fire in two coastal forests in New South Wales. CSIRO (Aust.) Div. Entomol. Tech. Pap. No. 7, PP. 4-18.

Green Heritage Committee of the Forestry Council. 1978. Eucalyptus: tree of the year. P.0. Box 4430. Pretoria 0001.

Groulez, J. 1970. An outline of the data presented at the Lisbon Symposium on the Growing and Industrial Use of Eucalypts. Transl. from Bois For. Trop. No. 136 by R. V. Champagne, For. Timber Bur. Aust.

Hal1, N., R.D. Johnston, and G.M. Chippendale. 1975. Forest trees of Australia.

Hall, N., R.D. Johnston, and R. Marryatt. 1963. The natural occurrence of the eucalypts. For. and Timber Bur. Aust. Leafl. 65 (2nd Ed.) $122 \mathrm{p}$.

Herms, William R. and $O$. Gordon Langdon. 1976. Development of loblolly pine in dense stands. For. Sci. 22(3):331-337.

Hartley, A. 1977. The establishment of Eucalyptus tereticornis on tailings from the Bouganville Copper Mine, Papua New Guinea. Commonw. For. Res. 56(3): 239-245. 
Hartney, V.J. 1980. Vegetative propagation of the eucalypts. Aust. For. Res. 10:191-211.

Hassan, A.E. 1977. Effect of mechanization on forest soils and regeneration. Coastal Plain Organic Soil. Am. Soc. Agric. Eng. Pap. 77-1571, $24 \mathrm{pp}$.

Heather, W.A. and D.M. Griffen. 1978. The potential for epidemic disease. In: Hillis, W.E. and A.G. Brown (ed.) Eucalypts for Wood Production. pp. 143-154.

Heilman, P.E., D.V. Peabody, Jr., D.S. DeBell, and R.F. Strand. 1972. A test of close-spaced, short-rotation culture of black cottonwood. Can. Jour. of For. Res. 2(4):456-459.

Hillis, W.E. and A.G. Brown. Editors. 1978. Eucalypts for wood production. 434 p. Comonwealth Scientific and Industrial Research Organization. Melbourne, Victoria. Griffin Press Ltd. Adelaide, S. Australia.

Hodges, C.S., M.S. Reis, F.A. Ferreira and J.D.M. Henfling. 1976. O cancro do eucalipto causado por Diaporthe cubensis. Fitopathol. Brasileira $1: 129-170$.

Hodges, C.S., T.F. Geary, and E.C. Cordell. 1979. The occurrence of Diaporthe cubensis on Eucalyptus in Florida, Hawaii, and Puerto Rico. Plant Dis. Reptr. 63:216-220.

Horvath, R. J. 1968. Addis Ababa's eucalyptus forest. Journ. of Ethiopian Studies, 6:13-19.

Howland, P. 1969. Effects of singling coppice in E. saligna wood fuel crops at Muguga, Kenya. East Afric. Agric. For. J. 35,66-7.

Howlett, K. and A. Gamache. 1977. Silvicultural biomass farms. Vol. II The Biomass Potential of Short Rotation Farms. Energy Res. and Dev. Administration. Div. Solar Energy. MTR-7347 (Vol. II) 119 PP.

Inman, R.E. 1977. Silvicultural biomass farms. Vol. I. Sumary. Energy Res. and Dev. Administration. Div. of Soalr Energy. MTR-3747 (Vol. I) $62 \mathrm{pp}$.

Jackson, J.K. and G.O.A. Oio. 1973. Provenance trials of Eucalyptus camaldulensis in the Savanna region of Nigeria. Fed. Dept. For. Res., Nigeria, Savanna For. Res. Sta., Res. Pap. No. 14. 
Johnson, Warren 0. 1970. Minimum temperatures in the agriculturil areas of peninsular Florida. Summary of 30 winter Seasons--1937-67.

IFAS. Publ. No. 9. Sept. Unv. of FL, Gainesville.

Johnson, R.C. 1980. Energy from biomass: the implications of gasohol. McLean, VA: The MITRE Corp.

Johnson, R. Channing, Rodney K. Lay, Lawrence C. Newman. 1980. Energy from biomass: a technology assessment of terrestrial biomass systems. The Mitre Corp. McLean, VA. MTR-80W259. December.

Johnston, R.D. and R. Marryatt. 1965. Taxonomy and nomenclature of eucalypts. For. and Timber Bur. Aust. Leaf1. 92, $24 \mathrm{p}$.

J.P.R. Associates, Inc. 1981. Whole-tree chippers' handbook. May. Publ. by Evergreen Energy Corp. $200 \mathrm{Fifth}$ Ave. Waltham, MA 02154.

Karschon, R. and D. Heth. 1967.. The water balance of a plantation of kucalyptus camaldulensis Dehn. Reprint from Contributions on Eucalyptus in Israel, III. National and University Inst. of Agr. Rehovat.

Kaul, O.N. and J.D.S. Negi. 1979. Comparitive transpiration rates of six eucalyptus species. For. Res. Inst. Dehra Dun. July.

Kennedy, H.E. 1975. Influence of cutting cycle and spacing on coppice sycamore yields. So. For. Exp. Sta. Res. Note So-193.

Kerruish, C.M. 1977. Developments in harvesting technology relevant to short rotation crops. APPITA 31:41-8.

Kerruish, C.M. 1978. Harvesting. In: Eucalypts for Wond Production. Hillis and Brown (ed.) PP 229-255.

King, James P. and Stanley L. Krugman. 1980. Tests of 36 eucalyptus species in Northern California. Pac.S.W. For. and Rge. Exp. Sta. Berkeley, CA. March.

King, Tony and Sharon Haines: 1979. Soil compaction absent in plantarion thinning. South. For. Exp. Sta. Res. Note So-251.

Klass, Donald I. (editor) 1981. Biomass as a nonfossil fuel source. ACS Symposium Series 144. American Chemical Society. Washington, D.C.

Kohan, S.M. and P.M. Barkhordar. 1979. Thermochemical conversion of biomass to fuels and chemicals. Mission Analysis for the Fereral Fuels from Biomass Program. Vol. IV. Menlo Park, CA: SRI International.

Krohn, Timothy J. 1981. Fertilization of Eucalyptus tereticornis in Southern Guam. Tree Planters Notes. 
Krugman, Stanley L. 1974. Eucalyptus L'Herit. In: Seeds of Woody Plants in the U.S. USDA Agr. Hdbk. No. $4 \overline{50}$.

Kuhlman, George E. and Edward L. Barnard. Diseases of eucalypts. In: Eucalyptus Handbook for Southern United States. Chapter XI. In Manuscript.

Laird, Cubie R. 1972. Fertilization of slash pines on poorly-drained soils in northwest florida. Cir. 378. Fla. Coop. Ext. Serv. IFAS. Unv. of Florida. Gainesville.

Landsberg. H., H. Lippmann, K. Paffen, and C. Troll. 1965. World maps of climatology. Springer-Verlag. New York.

Lawyer, J.N. and R.B. Fridley. 1979. Some aspects of machine planting for forest regeneration. ASAE Pap. No. 79-1614, 22 PP.

LeBarron, Russell K. 1962. Eucalypts in Hawaii: a survey of practices and research programs. Pac. S.W. For. and Rge. Exp. Sta. Misc. Pap. No. 64. Berkeley, CA. U.S. Dept. of Ag.

Ledig, F. Thomas. 1981. Silvicultural systems for the energy efficient production of fuel biomass. In: Biomass as a Nonfossil Fuel.

ACS Symposium Series 144. American Chemical Society. Washington, D.C. PP. 447-461.

Leppik, E.E. 1970. Gene centres of plants as sources of disease resistance. Annu. Rev. Phytopathol. 8, 323-44.

Loomis, R.C. and W.H. Padgett. 1973. Air pollution and trees in the East. USDA Forest Service. Northeastern and southeastern area, Slate and private forestry. Atlanta, GA. 28 PP.

Luckoff, H.A. 1955. The establishment and regeneration of Eucalyptus saligna plantations in the coastal belt of zululand. J. S. Afr. For. Assoc. (25) 1-20.

Lugo, Ariel E. 1970. The ecological role of fertilizers in relation to forest productivity and dollar subsidy by man. pp. 21-33. Proceedings of the Florida Section, Society of American Foresters, Gainesville, FL.

Malajczuk, N., A.J. McComb, and J.F. Lonergan. 1975. Phosphorus uptake and growth of mycorrhizae and infected seedligs of Eucalyptus callophylla. Aust. J. Bot. 23, 231-8.

Mariani, E.W., W.A. Wood, P.C. Kouchouk, M.B. Minton and Marelco, Inc. 1978. The eucalyptus energy farm-feasibllicy study and demonstration-Phase I: Site and species selection. U.S. Dept. of Energy, Washington, D.C. HCP/T2557-01, UC-61. 
Martin, John P. in press. Planting eucalyptus in the south Atlantic Coastal plain, North Florida, and the gulf coastal plain. Westvaco Corporation. Summerville, S.C.

McAlpine, R.G., C.L. Brown, A.M. Herrick and H.E. Ruark. 1966. Silage sycamore. Forest Farmer 26:6-7.

McAlpine, R.G. and C.I. Brown. 1967. Outlook for fiber from short-term coppice rotations. Tech. Pap. Amer. Pulpwood Assoc. (Apri1) (15-16, 18).

McArthur, A.G. 1967. Fire behaviour in eucalypt forests. For. Timb. Bur. Aust. Leafl. No. 80 .

McArthur, A.G. 1968, Fire resistance of eucalypts. Proc. Ecol. Soc. Aust. 3:83-90.

Mcknight, J.S. 1970. Planting cottonwood cuttings for timber production in the South. USDA For. Serv. Res. Paper SO-60.

MeNally, J. 1957. A field survey of a koala population. Proc. R. Zool. Soc. N.S.W. 1955-56, 18-27.

Meskimen, George. 1971. Combating grass competition for eucalypts planted in turf. Reprint from Tree Planter's Notes. 21(4).

Meskimen, G. 1979. Growth and yield in South Florida's oldest Eucalyptus plantations. Forest Servire, IISDA. Lehigh Acres, FL, Revised 1980.

Meskimen, G. and E.C. Franklin. 1978. Spacing Eucalyptus grandis in southern Florida: a question of merchantable versus total volume. Southern Jour. of Applied Forestry. Vol. I, No. 1. February.

Meskimen, G. and E.C. Franklin. 1978a. Spacing eucalypeus in Florida Trail. USDA For. Serv. Res. Note SE-162. $8 \mathrm{p}$.

Metcalf, W. 1961. Progress with eucalypts in North America 1956-61 (United States Mainland). National Report for Second World Eucalyptus Conferance, Sao Paulo, Brazil. August.

Miyata, Edwin S. 1980. Determining fixed and operating costs of logging equipment. North Central For. Exp. Sta. St. Paul, Minn. USDA For. Serv. Gen. Tech. Rep. NC-55.

Moehring, D.M. and I.K. Rawls. 1970. Detrimental effects of wet weather logging. J. For. $68(3): 166-67$.

Momoh, 2.0. and I.A.S. Gibson. 1975. Status of diseases and insect pests in Africa and Eurasia. Second FAO World Tech. Consultation on Forest Diseases and Insects. New Delhi, April. 
Moore, W.H. and B.F. Swindel. 1980. Effects of site preparation on dry prairie vegetation in South Florida. Southern J. of Applied Forestry. Vo1. 5(2):89-92.

Morbark Industries, Inc. 1980. Cost per ton for producing whole tree chips. Model 22RXL Total Chiparvestor. June.

Morrow, P.A. and V.C. LaMarche, Jr. 1978. Tree ring evidence for chronic insect suppression of productivity of sub-alpine Eucalyptus. Sci. Vol. 201(29): 1244-1246.

Motley, E.P., B.G. Cruz, L. McClanathan and J.A. Anastasi. 1980. Potential application of biomass technology at natioual space technology laboratories and Mississippi army ammunition plant. U.S. Army Armament Research and Development Command. Iarge Caliber Weapon Systems Laboratory. Dover, New Jersey.

Mount, A.B.. 1968. The effect of plant wastes on forest productivity. Proc. 5th general conf. IFA, Perth, Australia.

Myburgh, H.H. 1967. Kraft pulping of eucalypts in South Africa. APPITA $21: 49-53$.

0lawoye, 0.0. 1972. Economic investigation of silage sycamore production. Ph.D. Dissertation, Ohio St. Univ. Columbus.

Office of Technology Assessment. 1980. Energy from biological processes. Draft Report. Washington, DC: Office of Technology Assessment.

Opie, J.E., R.A. Curtain and W.D. Incoll. 1978. Stand thanagement: In: Eucalyptus for Wood Production. Hillis and Brown (eds.). Pp. 179-197.

Papadakis, J. 1970. Climate of the world. Ubro de Edicon, Argentina. 47 pp.

Penford, A.R. and J.I. Willis. 1961. The eucalypts: botany, cultivation, chemistry, and utilization. 551 pp. Interscience Publishers, Inc. New York.

Pickford, G.D. and R.K. LeBarron. 1960. A study of forest plantations for timber production on the is land of Hawaii. Tech. Pap. No. 52. Dec. Pac. SW For. and Rge. Exp. Sta. Berkeley, CA. Dept. of Agriculture and Conservation, Hawaii.

Plotkin, Steven E. 1980. Energy from biomass/the environmental effects. Environment 22:6. November. 
Podger, F.D. 1975. Fast growing hardwoods for developing countries:the forest disease and insect pest position. Second FAO World Technical Consultation on Forest Diseases and Insect. New Delhi. April 7-12. FAO/IUFRO/1/75/16-0/(b).

Pong, T.Y. 1974. The termite problem in plantation forestry in Peninsula Malaysia. For. Res. Inst. Kepong Mimeo.

Pryor, L.D. 1956. Chlorosis and lack of vigour in seedlings of renantherous species of Eucalyptus caused by mycorrhizae. Proc. Linn. Soc. N.S.W. $81,91-6$.

Pryor, L.D. 1977. Breeding habits of the Eucalyptus in relation to introduction and improvement throughout the world. Invited Lecture, Third World Conferences on Forest Tree Breeding.

Riekerk, H., J:C. Hendrickson and W,S. Gain. 1981. Site and environmental effects of trep hiomass filvioulture. 1781 Totaruliumal cao Reseatrh Conforenco, Scpt. - Oet. Lüs Augeles, CA.

Ride, W.D.L. 1970. A guide to the Native Mammals of Australia. Oxford Univ. Press: Melbourne.

Rockwood, D.L. and L.F. Conde. 1975. Genetic variation for biomass production in Eucalyptus grandis. IUFRO Symposium and Workshop on Genetic Improvement and Productivity of Fast Growing Species.

Rockwood, D.I. and A.E. Squillace. 1981. Increasing alcohol production from wood by utilizing genetic variation in wood characteristis. TAPPI.

Rolls, E.C. 1969. They all ran wild. Angus and kobertson, Sydney, Austra1ia. 444 PP.

Rose, D.W. 1975. Cost of producing energy from wood in intensive cultures. Juur, of Env. Management. 5, 23-35. (1977).

Rose, D.W. 1976. Economic investigations of intensive silviculure systems. Iowa State Jour. of Res. 50(3):301-315.

Rose, D.W. 1977. Cost of producing energy from wood in intensive cultures. Jour. of Env. Man. 5:23-35.

Rose, D.W. and R.D. Rallstrom. 1976. Economic feasibility of intensive culture. In: Intensive Plantation Culture: 5 years research. U.8. Dept. of Agr. For. Serv. Gen. Tech. Rep. NC-21. p. 96-108. U.S. Dept. of Agr. For. Serv. North Cent. For. Exp. Sta., St. Paul Minn.

Rose, D.W. and D.S. DeBe11. 1978. Economic assessment of intensive culture of short-rotation hardwood crops. Jour. of For. 76:706-711.

Rose, Dietmar, Karen Ferguson, David C. Lothner and J. Zavitkovski. 1981. An economic and energy analysis of poplar intensive cultures in the Lake States. USDA For. Serv. Res. Pap. NC-196. North Cent. For. Exp. Sta. 
Sachs, Roy M., David W. Gilpin and Tom Mock. 1980. Short-rotation eucalyptus as a biomass fuel. Califorria Agriculture. Aug-Sept.

Sajdak, R.L., Y.Z. Lai, G.D. Mroz and M.F. Jurgensen. 1981. Forest biomass for energy. In: Biomass as a nonfossil fuel. ACS Symposium Series 144. American Chemical Society. Washington, D.C. PP 21-48.

Salo, D.J., R.E. Inman, B.J. McGurk and J. Verhoff. 1977. Land suitability and availability. Silvicultural Biomass Farms. Vol. III. MTR-7347 McLean, VA: The MITRE Corp.

Salo, D.J., J.F. Henry and R.E. Inman. 1979. Design of a pilot silvicultural biomass farm at the Savannah River Plant. NTIS. March. The MITRE Corp.

Schonau, A.P.G. 1977. Initial responses to fertilizing Eucalyptus grandis at planting are sustained until harvesting. S. Afr. For. J. (100) 72-80.

Schonau, A.P.G., R. Verloren van Themaat, and D.I. Boden. 1980. The importance of complete site preparation and fertilizing in the establihsment of Eucalyptus grandis. Wattle Research Institute, University of Natal. Pietermaritzburg, South Africa. 17 pp.

Schory, E.A., Sr. 1960. Eucalyptus planting guide for Florida. Fla. For. Serv. Ft. Myers. 17 pp.

Shukla, J. and Y. Mintz. 1982. Influence of land-surface evapotranspiration on the Earth's climate. Science. Vol. 215. March.

Siddiqui, K.M., M, Rhan, S. Akhtar. 1979. Results of 10-year old Eucalyptus camaldulensis Dehn. provenance study at Peshawar. Pakistan Forest Institute, Peshawar.

Simoes, J.W., H.J.O. Rrough, A.D. Ciero Neto, and R.M. Pompeu. 1972. Influencia do vigor das arvores sobre a brotacao das toucas de eucalipto. IPEF $5,51-6$.

Smith, J.H.G. and D.S. DeBell. 1973. Opportunities for short-rotation culture and complete utilization of seven northwestern tree species. Forestry Chronicle 49(1).

Smith, W.H. and L.F. Conde. 1980. Energy and chemcials from woody species in Florida. Annual Report to U.S. Dept. of Energy, Grant No. ET-786-01-3040, School of Forest Resources and Conservation, Unv. of Fla. Gainesville. 
Solar Energy Reserach Institute. 1979. Synopsis and executive summary. A Survey of Biomass Gasification. Vol. I. Golden Co: Solar Energy Research Institute.

Spurgeon, David. 1980. The promise of agroforestry. American Forests. 86(10) October. Publ. by The American Forestry Association.

Steinbeck, D. R.G. McAlpine, and J.T. May. 1972. Short-rotation culture of sycamore: a status report. J. For. 70:210-213.

Steinbeck, K. 1973. Short-rotation forestry in the United States: a literature review. Proc. Am. Tnst. Chom. Eng:, Now Orleans, LA, March 11-15.

stibbe, E. 1975. Soil Molsture depletion in summer by an eucalyptus grove in a desert area. Agro-Ecosystems 2:117-126. Elsevier Scientific Publishing Co., Amsterdam.

Stidd, Charles K., W.B. Fowler, and J.D. Helvey. 1975. Irrigation Increases rainfall? Science. Vol. 188. Pp. 279-281. April 18,

Tillman, D.A. 1977. Energy from wastes: an overview of present technologies and programs, PP 17-39. In: L.L. Anderson and D.A. Tillman. Fuels from Waste. Academic Press, New York.

Tillman, David A. 1978. Wood as an energy resource. Academic Press, New York. 249 pp.

Uhr, Selmer C., George Meskimen and Kenneth Hayes. 1972. Eucalyptus for pulp in south Florida. Pres. Sixth TAPPI Forest Biology Conference. Appleton, WI. May 2. 7 PP.

Uhr, Selmer C. 1976. Eucalypt --the wonder tree. American Foreses. $82(10): 42-43,59,60-63$.

Ursic, S.J. and P.D. Duffy. 1972. Hydrologic performance of eroded lands stabilized with pine. Proc. Mississipoi Water Resources Conference. pp. 203-216. Water Resources Research Institute, Mississippi State University, State College, Miss.

USDA Forest Service. 1967. Forestland Tree Planter. FnkT Report 2400-2, uSvA For. Serv. Equip. Development Ctr., San Dimas, CA. 
Vail, Charles W. 1979. A preliminary screening of woody plants as biomass crops on energy farms. U.S. Dept. of Energy. DOE/ET/23124-T1. Dec. $38 \mathrm{pP}$.

Walter, H. 1973. Vegetation of the earth. Springer-Verlag. New York. 237 PP.

Walters, Gerald A. 1980. Saligna eucalyptus growth in a 15 year old spacing study in Hawaii. Pac. S.W. For. and Rge. Exp. Sta. Res. Pap. No. PSW-151. Feb. U.S. Dept. of Agr.

Wan, E.I., J.A. Simmons, and T.D. Nguyen. 1980. Production of fuels and chemicals from synthesis gas. A Survey of Biomass Gasification Vol. III. Golden, CO: Solar Energy Research Institute.

Wang, Flora C., John Richardson, Katherine Carter Ewel and Edward T. Sullivan. 1981. Preliminary energy analysis of utilizing woody biomass fuel. In: W.J. Mitsch, R.W. Bosserman and J.M. Klopatek. 1981. Energy and Ecological Modelling. Elsevier, $N Y$.

Wardle, P.A. 1967. Spacing in Plantations: a management investigation. Forestry $40(1): 47-69$.

Warren, Jack. 1977. Logging cost anaysis, timber harvesting short course. Timber harvesting Rep. 4. LSU/MSU Logging and Forestry Operations Center, Bay St. Louis, M.S.

Wattle Research Institute. 1981. Report for 1980-1981 (Thirty-Fourth Year). October. ISBN 0869802631 . Unv. of Natal. Pietermaritzburg, South Africa.

Watts, 1971.

White, E.H. and D.D. Hook. 1975. Establishment and regeneration of silage plantings. Iowa State Jour. of Res. 49:287-296.

White, E.H. and W.L. Pritchett. 1970. Water table control and fertilization for pine production in the flatwoods. Ag. Exp. Sta. Inst. of Food and $\mathrm{Ag}$. Sci. Bul. 743 (tech) November.

Yang, Christine, Donald Murata and Curt Beck. 1977. Biomass energy for Hawaii. Vol. IV. Terrestrial and Marine Plantations. Institute for Energy STudies, Stanford University, Stanford, CA.

Zavitkovski, J. 1976. Biomass studies in intensively managed forest stands. PP. 32-37. In: Intensive plantation culture; five years research. USDA For. Serv. Gen Tech. Rep. NC-21, North Cent. For. Exp. Sta. St. Paul, MN. 
Zavitkovski, J. 1979. Energy production in irrigated, intensively culture plantations of Poplus 'Tristis $\#^{1} 1$ ' and jack pine. N.C. For. Exp. Sta. St. Paul, MN.

Zon, Raphael and John M. Briscoe. 1911. Eucalypts in Florida. U.S. Dept. of Ag. For. Serv. Bul. 87. 
PERSONAL COMMUNICATIONS

Allen, J. Allen frove Service. Lakeland, Florida. (813) 686-2833.

Boulay, Michel. AFOCEL. France.

Bradley, Ed. Southern Machinery. Lakeland, Florida. (813) 644-6661.

Chancey, Joe. Chancey Trailers. Jacksonville, Florida. (904) 396-2891.

Cowan, Frank. Forester. Floral City, Florida. (904) 726-4061.

Cremer, Ernest. Cremer Timber Company. Palatka, Florida. (904) 328-5058.

Darr, David. U.S. Forest Service. Portland, Oregon. (503) 231-2088.

Demarest, Don. Speedling, Inc. Ruskin, Florida. (813) 645-3261.

Dixon, Wayne. Florida Division of Forestry. Gainesville, Florida. (904) 372-3505.

Draper, Lee. Container Corporation of America. Callahan, Florida. (904) 879-3051.

Eloff, Don. Ring Power Corporation. Ocala, Florida. (904) 732-2800.

Franklin, E. C. Franklin Forestry Associates. Apex, North Carolina. (919) 362-5958.

Futch, Jonathon. Futch Timber Company. Homerville, Georgia. (912) 4872545.

Hebb, Mark. Florida Division of Forestry. Lakeland, Florida. (813) 6462959.

Lancaster, Bill. Timberjack, Inc. Perry, Florida. (904) 584-5063.

Lee Timber Company. Ft. Myers, Florida. (813) 334-3132.

Martin, J. A. Martin Lumber Company. Wachula; Fiorida. (813) 773-6736.

Meskimen, George. U.S. Forest Service. Lehigh Acres, Florida. (813) 3344579 .

Swendsen, Ben. Lykes Bros. Ranch. Palmdale, Florida. (813) 763-3545. 